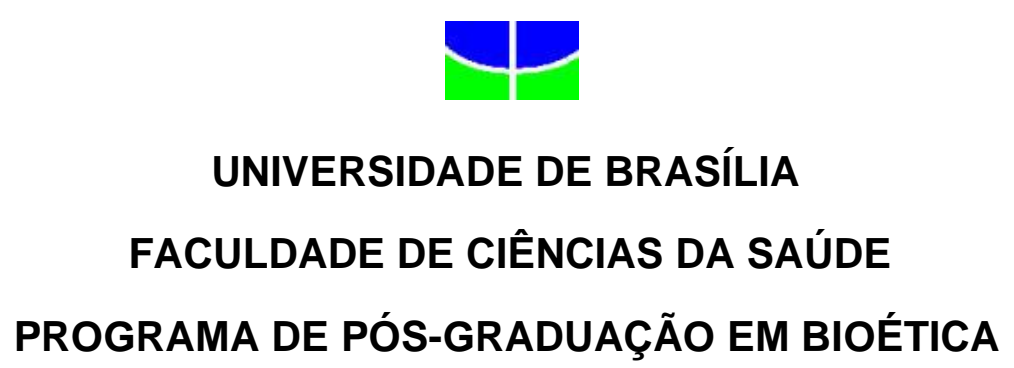

DALVINA BENICIO DO NASCIMENTO

ANÁLISE BIOÉTICA DA UTILIZAÇÃO DE IMAGENS DE PACIENTES

EM MÍDIAS SOCIAIS ELETRÔNICAS 
DALVINA BENICIO DO NASCIMENTO

\title{
ANÁLISE BIOÉTICA DA UTILIZAÇÃO DE IMAGENS DE PACIENTES EM MÍDIAS SOCIAIS ELETRÔNICAS
}

\begin{abstract}
Dissertação apresentada como requisito parcial para obtenção do grau de Mestre em Bioética pelo Programa de Pósgraduação em Bioética da Universidade de Brasília.
\end{abstract}

Orientador: Prof. Dr. Natan Monsores de Sá 
NASCIMENTO, DALVINA BENICIO do. ANÁLISE BIOÉTICA DA UTILIZAÇÃO DE IMAGENS DE PACIENTE EM MÍDIAS SOCIAIS ELETRÔNICAS. 2016. 103 f. Dissertação de mestrado (Programa de Pósgraduação em Bioética) - Faculdade de Ciências da Saúde, Universidade de Brasília, Brasília-DF.

Dissertação aprovada em 15/02/2016

\section{BANCA EXAMINADORA}

Prof. Dr. Natan Monsores de Sá

Orientador(UnB)

Prof. Dr. Leandro Brambilla Martorell

Avaliador externo (UFG)

Prof. Dr. Volnei Garrafa

Avaliador interno (UnB)

Prof. Dr. Fabiano Maluf Membro suplente (SES-DF) 
Ao iniciar meu trabalho na UnB, em 2010, tinha grande expectativa de fazer cursinho de informática e de inglês. Cheguei cheia de sonhos e vontade de estudar um pouco mais para complementar minha formação. Tão logo, foi minha frustação; infelizmente eu não poderia fazê-los, pois eram disponíveis apenas aos servidores efetivos e, na minha função de estagiaria técnica (recém-formada), não poderia cursar nenhum. Isso entristeceu-me, mas não me abateu. Prestei meu serviço com a maior qualidade que pude: dedicação, responsabilidade e compromisso; conquistei confiança e mudei de setor. Quando tudo parecia chegar ao fim (final do contrato), nasceram as possibilidades de que tanto almejava, vieram as bênçãos: primeiro a bolsa para o curso de especialização em bioética, depois a de mestrado, e agora a um passo para ingressar no doutorado.

Por todas as oportunidades, pelo acesso concedido para os estudos, pela ajuda, pela compreensão, dedico imensamente a todos que de alguma forma me ajudaram a chegar até aqui. Mas gostaria de dedicar especialmente à algumas pessoas, sem ordem de importância, porque todos foram imprescindíveis em minha vida, em minha caminhada.

Ao meu orientador Prof. Dr. Natan pelo ajuda, paciência e compreensão de sempre.

Ao professor Dr. Volnei Garrafa, pelas oportunidades e por acreditar em mim.

Ao meu amigo e irmão de coração, psicólogo nos meus momentos de desespero, Camilo Manchola.

A minha amiga Rosimara Alves por ajudar-me a ingressar na UnB.

À minha amiga Lízia por sua ajuda imprescindível para a minha participação na seleção para o mestrado!

Aos meus amados pais Conegundes B. Nascimento Maria Raimunda C. De Queiroz. À minhas queridas irmãs, e mus lindos e amados sobrinhos!

Dedico a vocês esta conquista. 


\section{AGRADECIMENTOS}

À Deus;

À Cátedra Unesco de Bioética e ao Programa de Pós-Graduação pelas oportunidades, pela confiança e pela bolsa concedida, sem a qual, não teria sido possível fazer o curso.

Ao meu orientador Prof. Dr. Natan Monsores de Sá, por ajudar me desde o início, pela paciência, pelas palavras de incentivo, pela disponibilidade e delicadeza ao longo deste trabalho.

À banca examinadora.

Aos meus pais que mesmo sem estudo, ensinaram-me a ter caráter, a respeitar o outro, a não me apossar do que não conquistei, e a ser uma pessoa com sensibilidade à necessidade alheia.

Á minha amiga Lízia Fabiola, que sem sua ajuda não teria conseguido fazer a seleção para o mestrado.

Aos colegas de turma do mestrado em Bioética, pela convivência, pela colaboração no aprendizado, em especial ao meu amigo e irmão de coração Camilo Manchola, Nilceu Oliveira, Fábio Rivaz, André Lemos, Iris Santos e Patrícias Duarte

Ao Professor Volnei pela oportunidade concedida, pela confiança, pelo carinho e cuidado paternal que tem com os alunos. Estendo aqui os agradecimentos a todos os professores e funcionários do PPGBioética.

À diretoria da SBB pelo apoio e compreensão, nessa reta final de escrita da dissertação.

À minha amiga Natasha Lunara por sua ajuda, incentivo e torcida.

Às minhas amigas Rosimara Alves e Luzia Teodoria.

Enfim, a todos meus familiares e amigos pela torcida e apoio. 
"É preciso amar as pessoas e usar as coisas e não, amar as coisas e usar as pessoas".

"Há pessoas que nos falam e nem as escutamos, há pessoas que nos ferem e nem cicatrizes deixam, mas há pessoas que simplesmente aparecem em nossas vidas e nos marcam para sempre".

Cecília Meireles 


\section{RESUMO}

Este trabalho propôs uma investigação para conhecer a percepção ética de estudantes da área de saúde da Universidade de Brasília, sobre a divulgação da imagens/vídeos e informações sobre pacientes em mídias sociais, como Facebook, WhatsApp e Instagram, tomando como marco referencial teórico os relacionamentos fluidos na pós-modernidade, preceitos defendidos por Bauman; e a Declaração Universal sobre Bioética e Direitos Humanos. O estudo é de natureza descritiva e exploratória. Foi aplicado questionário a 94 estudantes, composto por questões fechadas e abertas, para averiguar a percepção ética dos estudantes. Após a coleta de dados, foi realizada correlação das respostas com o referencial teórico escolhido. Ficou perceptível certa contradição no discurso em relação a prática evidenciada na literatura e nos comentários dos próprios estudantes. Foi constatada a presença frequente do uso de imagens de pacientes nas práticas de ensino com autorização na maioria das vezes, apenas verbal; feita na presença de professores/preceptores. Houve algumas publicações em redes sociais, apesar dos estudantes considerarem que divulgação de foto/ filme de paciente sem permissão pode violar algum princípio ético. A forte presença de ações inadequadas dos estudantes, mesmo com a presença de professores, demostra estar faltando o exemplo virtuoso do professor para a prática da educação em saúde. Grande parte dos estudantes afirmou não conhecer nenhuma norma ou lei que trata acerca do uso de imagens de pessoa ou paciente. Salienta que é fundamental uma educação em ética e bioética para sanar as ocorrências de desrespeitos dos direitos dos pacientes frente ao uso de mídias sociais eletrônicas. Ao conceituarem privacidade, confidencialidade e sigilo fizeram certa confusão na definição dos conceitos. Os resultados evidência de que se faz necessário emprego do ensino de bioética com maior abrangência para evitar questões éticas de apropriação indevidas de imagens de pacientes e exposição nas redes sociais.

Palavras Chave: Redes sociais; Privacidade; Pacientes; Imagens; Bioética 


\begin{abstract}
This thesis proposes an investigation to know the ethical perception of students in the health area of the University of Brasilia, on the disclosure of images / videos and patient information in social media like Facebook, WhatsApp and Instagram, taking as theoretical March relationships fluids in postmodernity, principles defended by Bauman; and the Universal Declaration on Bioethics and Human Rights. The study is descriptive and exploratory nature. questionnaire was applied to 94 students, with closed and open questions, to ascertain the ethical perception of students. After data collection, correlation was made of the responses to the chosen theoretical framework. It was noticeable certain contradiction in discourse regarding the practice evidenced in literature and comments from the students themselves. the frequent presence of the use of patient images in teaching practices authorized in most cases, only verbal was found; made in the presence of teachers / tutors. There were some publications on social networks, despite the students consider that publicity photo / patient without permission film may violate any ethical principle. The strong presence of inappropriate actions of the students, even with the presence of teachers, demonstrates be missing the virtuous example of the teacher to the practice of health education. Most students said they did not know any rule or law that deals about the use of images of people or patient. It stresses the importance of an education in ethics and bioethics disrespect to remedy the instances of patients' rights against the use of electronic social media. To conceptualize privacy, confidentiality and secrecy did some confusion in the definition of concepts. The results evidence that it is necessary to use of bioethics education with greater scope to avoid ethical issues of misappropriation of patient and display images on social networks.
\end{abstract}

Keywords: Social Networking Sites; Privacy; Patients; Images; Bioethics. 


\section{LISTA DE TABELAS E SIGLAS}

Tabela 1- Dados de caracterização da amostra, referentes ao sexo, filhos, estado civil, cor ou raça.

Tabela 2 - Dados de caracterização da amostra, referentes ao local de residência, renda familiar, instituição em que cursou o ensino fundamental e médio.

Tabela 3 - Dados de caracterização da amostra, referentes a universidade que estuda, o curso de graduação, e em qual semestre está cursando.

Tabela 4 - Dados que demostram a interação entre profissional de saúde com os pacientes, sobre: contato com paciente(s) durante o curso, quem é o protagonista na relação paciente e profissional de saúde, se já tirou foto ou fez algum filme de paciente, se conhece. .34

Tabela 5 - Dados de onde, quando e porque as/filmes foram feitos. 35

Tabela 6 - Dados referentes a ação do profissional de saúde em obter ou não fotos ou filme de pacientes no ato do atendimento: se pediu autorização; se a autorização foi escrita, verbal ou outras formas; se havia algum supervisor e se este era professor, preceptor servidor do hospital, outros.

Tabela 7 - Dados referentes a postura do profissional de saúde quanto a captura e finalidade de imagem e/ou vídeos de pacientes e a divulgação nas redes sociais ...41 Tabela 8 - Dados que mostram os motivos da divulgação de fotos/filmes em grupos fechados ou abertos.

Tabela 9 - Dados sobre a repercussão da divulgação da foto/filme se foi positiva ou negativa.

Tabela 10 - Dados referentes a percepção e a empatia com o paciente.

Tabela 11 - Argumentos pelos quais os estudantes justificam se autorizaria ou não a divulgação de fotos/filmes seus enquanto paciente.

Tabela 12 - Resposta dos estudantes sobre qual/quais seria(m) o(s) princípio(s) éticos violados na divulgação de fotos/vídeos em redes sociais.

Tabela - 13 Definição do conceito de autonomia do paciente, feita pelos estudantes do $10^{\circ}, 8^{\circ} 2^{\circ}$ e $1^{\circ}$ semestre.

Tabela 14 - Definição do conceito de privacidade do paciente, feita pelos estudantes do $10^{\circ}, 8^{\circ} 2^{\circ}$ e $1^{\circ}$ semestre. .53

Tabela 15 - Definição do conceito de confidencialidade, feita pelos estudantes do $10^{\circ}, 8^{\circ} 2^{\circ}$ e e $1^{\circ}$ semestre. 
Tabela 16 - Definição do conceito de sigilo, feita pelos estudantes do $10^{\circ}, 8^{\circ} 2^{\circ}$ e $1^{\circ}$ semestre. 55

Tabela 17 - Resposta dos estudantes se conhece alguma norma ou lei que oriente acerca da divulgação de imagens de pessoas...... 


\section{LISTA DE FIGURAS}

Figura - 1 Nuvem de palavras construída a partir das respostas da Tabela 5..........36 


\section{LISTA DE ABREVIATURAS E SIGLAS}

CFM - Conselho Federal de Medicina

CF - Constituição Federal

COFEN - Conselho Federal de Enfermagem

CNS - Conselho Nacional de Saúde

DUBDH - Declaração Universal sobre Bioética e Direitos Humanos

DUDH - Declaração Universal dos Direitos humanos

ECA - Estatuto da Criança e Adolescente

IBGE - Instituto Brasileiro de Geografia e Estatística

UNESCO - Organização das Nações Unidas para a Educação, Ciência e Cultura

TCLE - Termo de Consentimento Livre e Esclarecido 
1. INTRODUÇÃO

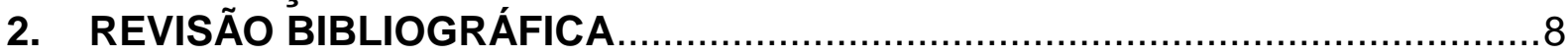

2.1. OS CONCEITOS DE PRIVACIDADE E DE CONFIDENCIALIDADE ............8

2.2. PRIVACIDADE DIGITAL E COMPORTAMENTO DE PROFISSIONAIS DE

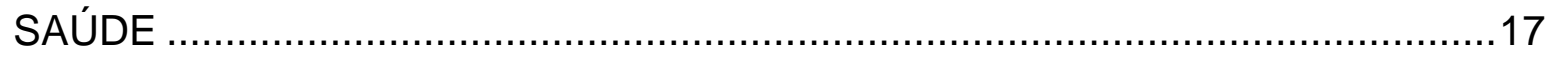

2.3. ASPECTOS JURÍDICOS DE PROTEÇÃO E NORMAS ….........................20

2.4.A DECLARAÇÃO UNIVERSAL SOBRE BIOÉTICA E DIREITOS HUMANOS 22

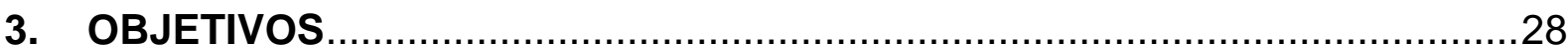

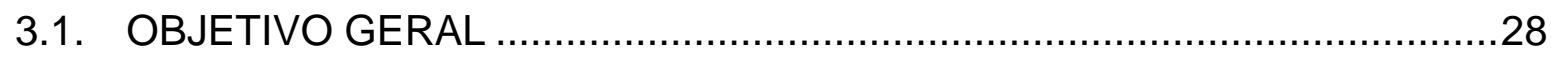

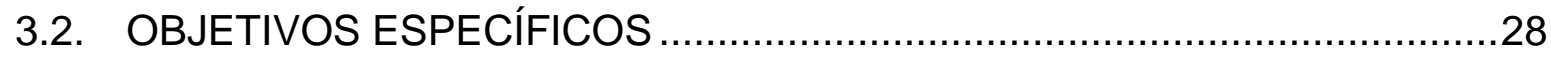

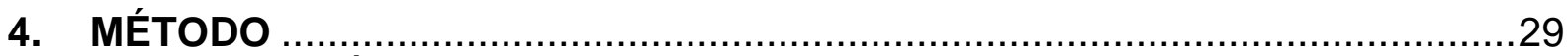

4.1. CARACTERÍSTICAS E UNIVERSO DE ESTUDO …..............................29

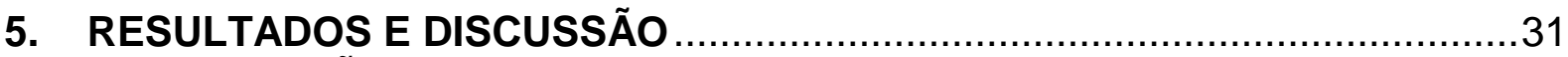

5.1. AVALIAÇÃO GERAL DOS DADOS POR SEMESTRE ............................59

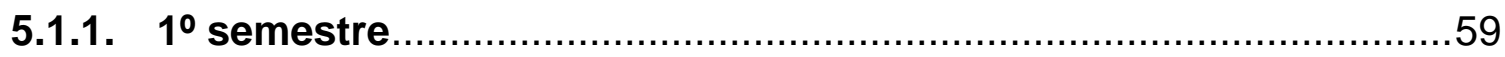

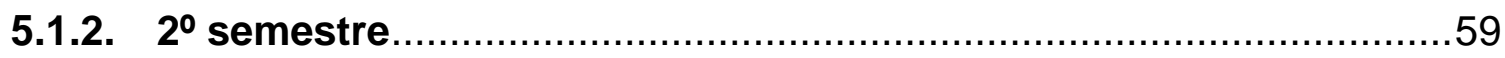

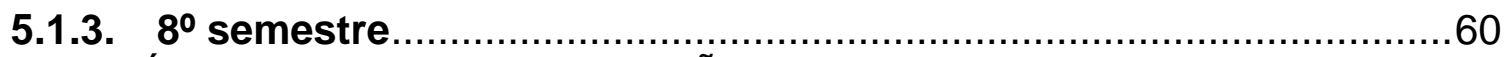

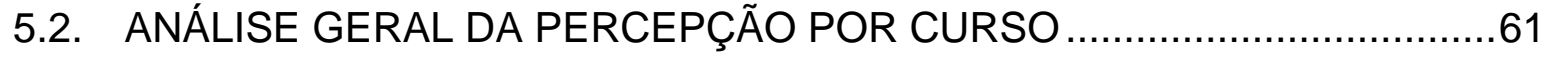

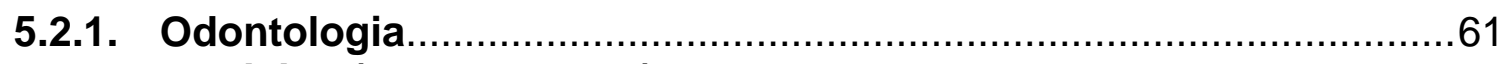

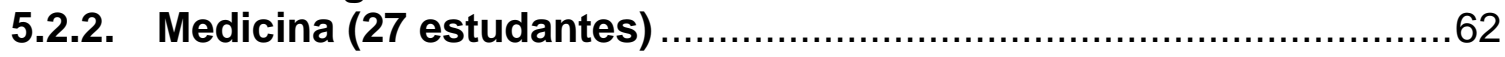

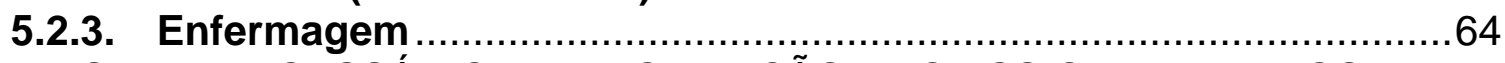

5.3. SERIA NECESSÁRIO UMA FORMAÇÃO PROFISSIONAL VIRTUOSA NA

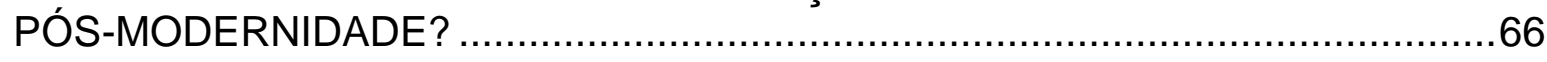

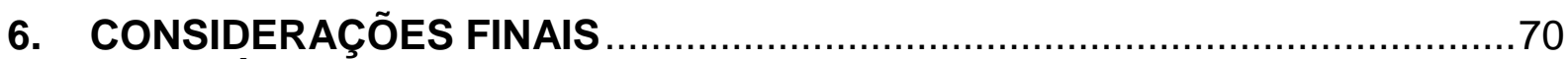

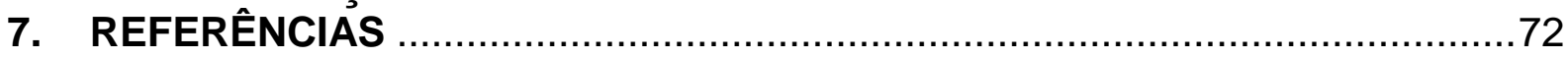




\section{INTRODUÇÃO}

O crescimento do uso de redes sociais virtuais tem sido exponencial no Brasil. São cerca de oitenta milhões de brasileiros com contas ativas em Social Networking Sites como Facebook, Instagram e Twitter ${ }^{1}$. Em paralelo, este novo hábito tecnológico tem dado nova roupagem para um clássico dilema da relação profissional-paciente: a violação do direito ao sigilo, à privacidade e à confidencialidade da informação. Deve-se salientar que a preservação das informações é considerara um dever prima facie de qualquer profissional de saúde que estabeleça um vínculo com um paciente ${ }^{2,3}$.

Desde o início da computação médica a questão da privacidade tem sido posta em evidência ${ }^{4-12}$. Na década de 1970, época de desenvolvimento dos primeiros sistemas de informação médica, a questão da relação entre computadores e privacidade dos pacientes começou a ser debatida; o desenvolvimento dos computadores e das redes trouxe em paralelo à questão da preservação da privacidade ${ }^{6,10-15}$.

Os registros eletrônicos de pacientes, particularmente os prontuários eletrônicos, são alvo de ampla discussão no campo da saúde ${ }^{14,16-20}$. Há controvérsias no que tange a segurança de dados, sobre quem deve ter acesso, sobre partilha de dados e sobre sua portabilidade. Soma-se aos registros os avanços nas ferramentas em telemedicina e telediagnóstico, que geram uma grande quantidade de imagens e informações biológicas ${ }^{16,18,21-25}$. Contudo, estes são registros oficiais ou institucionais que são amparados por preceitos legais bem definidos, ainda que existam lacunas ${ }^{22, ~ 26}$, diferindo da modalidade de compartilhamento de informações aqui abordada, que é a veiculação de fotos e vídeos de pacientes em redes sociais virtuais ${ }^{27-30}$.

No âmbito privado de um sistema de prontuário eletrônico (medical records), as formas de intervenção nas informações são estabelecidas por protocolos e normas, onde cada ação é registrada ${ }^{31-33}$. No caso da veiculação de informações de um paciente em redes sociais, este controle se encontra sob tutela dos provedores de serviço que, habitualmente nos termos de uso das redes sociais, estabelecem que não são responsáveis pelos dados adicionados pelos usuários ${ }^{34}$. Moubarak ${ }^{35} \mathrm{e}$ Martorell et a $\left.\right|^{36}$ têm chamado a atenção para as consequências legais e morais da veiculação de imagens de pacientes em tais redes. 
O uso de tecnologias móveis, em avaliação feita por pesquisa do Instituto Brasileiro de Geografia e Estatística (IBGE), é amplo no Brasi ${ }^{37}$. Mais da metade dos brasileiros estão conectados à internet. Em 2012 eram 49,2\% internautas, passando em 2013 para 50,1\%. A pesquisa apontou que, em 2013, houve crescimento do uso do celular como único meio telefônico nos domicílios. As pessoas a partir dos dez anos, que usam celular, representaram $75,5 \%$ da população brasileira, correspondente a 130,8 milhões de pessoas. O crescimento do uso do celular, de 2012 para 2013, ocorreu em todas as maiores regiões, na seguinte proporção: Norte $(5,6 \%)$, Nordeste $(6,2 \%)$, Sudeste $(4,5 \%)$, Sul $(4,9 \%)$ e Centro-Oeste $(5,1 \%)^{37}$.

Com isso, produziu-se um maior uso do WhatsApp, que é um aplicativo para uso em sistemas operativos Android, iOs, Windows Phone, BlackBerry, que possibilita a criação de grupos e a troca de mensagens, áudios e vídeos entre pessoas e grupos. O mesmo acontece com o Instagram ${ }^{38}$, uma rede social online de compartilhamento de foto e vídeo que permite aos seus usuários tirar fotos e vídeos, aplicar filtros digitais e compartilhá-los em uma variedade de Social Networking Sites, como Facebook ${ }^{39}$, Twitter $^{40,41}$, Tumblr $^{42}$ e Flickr ${ }^{43}$.

O Facebook é uma dessas redes sociais em que as pessoas divulgam e compartilham todo tipo de informações e principalmente imagens e vídeos. Esse, como plataforma da internet, permite aos seus usuários criarem um perfil onde uns podem ter acesso ao perfil dos outros, o que possibilita encontrar amigos, compartilhar diariamente informações, experiências, etc. Alguns divulgam informações comerciais para fins lucrativos, outros, informações pessoais expondo, desde os mínimos detalhes do seu dia a dia, até informações, imagens e vídeos de pessoas com as quais convivem, ou com quem apenas têm algum tipo de contato; e é neste contexto que são divulgadas fotos no interior de unidades clínicas ou hospitalares e de pacientes.

No campo da discussão bioética, Martorell e colaboradores apontaram que este é um problema moral que precisa ser discutido e aprofundado. Denunciam que esta é uma transgressão ética que precisa de novos olhares ${ }^{36}$. $O$ tema da utilização de imagens de pacientes tem sido debatido desde a década de $1970^{27,30,35,44-46}$, mas ganhou roupagem nova em tempos de internet. Desta forma, o que se buscou na presente pesquisa foi compreender um pouco do contexto e das escolhas morais que estudantes do campo da saúde fazem em relação à intimidade do 
paciente ou usuário do Sistema Único de Saúde (SUS), isto é, como compreendem a tríade privacidade-confidencialidade-sigilo em tempos de uso contínuo de smartphones e internet.

O marco normativo escolhido para apoiar a investigação foi a Declaração Universal sobre Bioética e Direitos Humanos - DUBDH ${ }^{47}$. Também se lançou mão de teóricos que discutem a questão das redes sociais na pós-modernidade, como Castells e Bauman. Este último estabeleceu uma concepção de que a pósmodernidade é liquida, com relacionamentos fluidos e perda da sensibilidade moral $48-50$

Bauman também destaca a atual conjuntura histórica, política e social, traçando um panorama preciso de como a sociedade e as pessoas, em tempos de internet, têm organizado suas vidas:

O que aconteceu no século XX foi uma passagem de toda uma era da
história mundial, ou seja, da sociedade de produção para a sociedade
de consumo. Por outro lado, houve os processos de fragmentação da
vida humana. [...]. No iń́cio deste século, as pessoas se preocupavam
com o o projeto de vida, e em executá-lo, passo a passo. Nos dias
atuais, isto não acontece, porque a vida é dividida em episódios,
fragmentados, o que não era assim no início do século XX. As
sociedades foram individualizadas. Em vez de se pensar em termos de
a qual comunidade se pertence, a qual nação se pertence, a qual
movimento político se pertence, etc., tentamos redefinir o significado
de vida, o propósito de vida, a felicidade na vida, para o que está
acontecendo com a própria pessoa, as questões da identidade que
têm um papel importante hoje, no mundo. A pessoa tem que criar a
sua própria identidade. A pessoa não a herda. Não apenas é
necessário fazer isso desde o iní́io da vida, mas é necessário passar
a vida, de fato, redefinindo a própria identidade. [...].Muitas mudanças,
não apenas a passagem do totalitarismo para a democracia, mas
muitas outras coisas mudaram... 51

Esta condução episódica da vida pode ser um importante fator para se compreender a relação da atual geração de estudantes com pacientes e futuros colegas de profissão. A noção de que cada instante (episódio) precisa de registro e de divulgação é uma característica da geração $Y$, que será alvo da presente investigação. Esta geração cresceu habituada a conectividade, às interações virtuais, às relações fluidas no trabalho e na vida pessoal ${ }^{52,53}$. E este grupo faz uso intensivo de redes sociais, dispensando grandes quantidades de horas em grupos ou comunidades virtuais em que há próximos morais ou indivíduos com afinidades culturais ${ }^{54-56}$. É na rede virtual que esta geração (e mesmo os adolescentes e jovens 
das classes desfavorecidas se conectam) tem constituído sua identidade e sensação de pertencimento. Nessas redes a imagem (o simulacro, o avatar) é elemento fundamental. Fotos, vídeos, memes, cartoons, mangás, gifs animados compõem, de maneira fluida e transitória, cada perfil individual destas redes. Cada imagem é compartilhada, replicada, encaminhada, difundida. São individualidades coletivizadas, simulacros translúcidos da vida no mundo real.

Pode-se afirmar que uma questão peculiar às redes sociais é que, de maneira geral, a autoria de uma imagem se torna difusa ${ }^{57}$. Para além do dilema foucaultiano $^{58}$ de que o consumo de uma obra (foto, vídeo, som, texto no caso da internet) decreta a "morte" do autor, tornando-se o apreciador da obra um novo autor, nas redes sociais o autor se multiplica ou se amplifica exponencialmente. Segundo Castells ${ }^{59}$ existe uma enorme penetrabilidade dos efeitos das novas tecnologias na sociedade, que se dá através da convergência tecnológica e dos novos comportamentos. Acompanhando esta lógica, pode-se afirmar que os efeitos da veiculação e da circulação de uma imagem em um ambiente complexo, dinâmico, interativo e aberto não permite a previsão exata de consequências morais ou sociais. A objetificação (reificação) da figura do paciente e a integração de sua imagem no imaginário coletivo dos usuários das redes sociais, mesmo que tenha havido consentimento prévio, precisa de uma reflexão mais aprofundada.

No campo da ética médica e da bioética, a questão do direito à privacidade tem sido discutida desde a década de 1960 60-62. Em tempos de avanço de microcefalia e de Zika vírus, cabe ressaltar que o debate público mais famoso no campo da ética médica, no que tange à privacidade, se deu em 1973. É o caso 410 U.S. da Suprema Corte Americana, conhecido como Roe versus Wade ${ }^{63-70}$; uma discussão a respeito do direito a decisão privada da mulher de abortar, sem interveniência externa ou do Estado. O aspecto de privacidade abordado neste caso é a privacidade sobre o corpo, um pouco diferente da questão do uso da imagem, a ser abordada no presente trabalho. Mas ambas são aspectos diferentes da mesma concepção de inviolabilidade daquilo que autonomamente é decidido como íntimo.

A discussão contemporânea sobre direito à privacidade remonta à primeira metade do século $X X^{71-78}$. Enquanto direito humano fundamental, teve apresentação formal na Declaração Universal dos Direitos Humanos: 
Ninguém será objeto de ingerências arbitrárias em sua vida privada, sua família, seu domicílio ou sua correspondência, nem de ataques a sua honra ou a sua reputação. Toda pessoa tem direito à proteção da lei contra tais ingerências ou ataques. ${ }^{79}$

E, como já afirmado, é um princípio bioético enunciado na DUBDH juntamente com a confidencialidade das informações:

A privacidade dos indivíduos e a confidencialidade de suas informações devem ser respeitadas. Com esforço máximo possível de proteção, tais informações não devem ser usadas ou reveladas para outros propósitos que não aqueles para que foram coletadas ou consentidas, em consonância com 0 direito internacional, em particular com a legislação internacional sobre direitos humanos. ${ }^{47}$

Alguns teóricos ${ }^{80}$ convencionaram definir privacidade como uma tríade de direitos:

(a) Direito de não ser monitorado, entendido como direito de não ser visto, ouvido, etc.

(b) Direito de não ser registrado, entendido como direito de não ter imagens gravadas, conversas gravadas, etc.

(c) Direito de não ser reconhecido, entendido como direito de não ter imagens e conversas anteriormente gravadas publicadas na Internet em outros meios de comunicação.

Não ser monitorado, registrado ou reconhecido estabelecem limites para decisão autônoma acerca do que se deseja sobre a própria imagem. São limites da liberdade individual que se estendem aos direitos dos pacientes, figurando em políticas de humanização e em cartilhas elaboradas pelo SUS e por diversas secretarias de saúde ${ }^{81}$.

Além do panorama complexo de discussão dos limites da vida privada e da intimidade, do direito a ser esquecido ${ }^{82} \mathrm{e}$ da garantia de privacidade, hoje a difusão tecnológica é elemento chave na compreensão de como o direito à privacidade precisa ser revisitado pelos bioeticistas. Dispositivos móveis como os aparelhos celulares, ipads e tablets evoluíram com o desenvolvimento e hoje são construídos com câmaras acopladas e acesso à internet. Isto proporciona grande capacidade de registro de informações, imagens e vídeos, de pessoas e/ou coisas; também permite a divulgação instantânea das mesmas em correio eletrônico e em redes sociais virtuais. Por um lado, estas ferramentas são um poderoso aliado na divulgação de novos conhecimentos, mas por outro lado, podem se tornar um canal capaz de 
propagar dados, imagens, vídeos e informações privadas, podendo causar danos e/ou prejuízos, violar a privacidade, a dignidade humana e direitos humanos de pacientes ${ }^{83-85}$.

Bauman $^{86,87}$ afirma que atualmente temos a nossa disposição à web mundial e a internet, que nos possibilitam conexão em "tempo real" por todo o planeta, por meio de pequenos aparelhos como lpods e smartphones, que carregamos para todos os lugares o tempo todo. Essa disponibilidade de acesso vem carregada de desafios para todas as áreas de interação humana, sendo na área da saúde um tanto mais delicado, por se tratar de pessoas em estado de maior fragilidade e vulnerabilidade.

Como já afirmado, na sociedade contemporânea, o uso de imagem e/ou vídeos em mídias sociais eletrônicas tem se tornado uma prática constante por todos os segmentos sociais ${ }^{88,89}$. A geração $Y$, que cresceu utilizando redes sociais, está habituada ao consumo de imagens e informação em grandes volumes. Nestes ambientes, o like and share ${ }^{90}$ é incentivado e recompensado, levando seus usuários a se apropriarem dos conteúdos circulantes e a difundi-los em seus grupos ${ }^{91}$. Há uma aparente relativização da privacidade e da noção de propriedade. Os compartilhamentos parecem ser superficiais/voláteis, não são reais compromissos. Muitas vezes são conflituosos entre si. Parece que em alguns casos sequer são lidos /interpretados, seria o efeito "avalanche" de informação, que não da tempo à reflexão. Da mesma forma que os limites sociais do mundo real, no imaginário dos jovens usuários, parece não ter o mesmo significado que nas redes; não é incomum a circulação de fotos íntimas, de ocorrências de cyberbullying ${ }^{92}$.

Estes novos limites líquidos apontam a necessidade de se investigar o comportamento de estudantes do campo da saúde ao estagiarem em hospitais e clínicas. A omnipresença dos smartphones e a compulsão pelo registro instantâneo digital de tudo e de todos ${ }^{93,94}$, pode levar os estudantes a registrarem pacientes para diversas finalidades, como por exemplo: estudo futuro, registro da doença ou da prática, apresentação de trabalhos. Todavia, no contexto de assistência em saúde, campo de prática dos estudantes, o paciente, vulnerado por sua situação de saúde, pode estar nu, desacordado, em estado crítico ou em situação na qual não poderiam ou gostariam de ser expostos. E, a depender do estado do paciente pode se levar a crer que, a obtenção do registro de imagem e sua exposição pública se produziu sem seu consentimento. 
Segundo Fabri \& Fortes $^{95}$, no início deste milênio, tanto a confidencialidade como a privacidade nas relações entre usuários, profissionais e instituição de saúde sofreram grande impacto pelo risco potencial de violação, podendo comprometer a confiança entre ambos. Para Francisconi \& Goldim $^{96}$, a privacidade atribui ao profissional de saúde a obrigação de proteger "as informações que teve contato e de preservar a própria pessoa do paciente", ainda que sua relação não seja direta, também pode se considerá-la como um dever da instituição de saúde. Também, a confidencialidade implica que o profissional de saúde se torna responsável a preservar as informações reveladas diretamente a si, pelos pacientes, visto que uma pessoa geralmente revela algo de sua intimidade quando se estabelece confiança, conforme Cohen ${ }^{97}$ explica:

a confiança surge da empatia com uma pessoa e da ideia de que o indivíduo ao qual revelaremos esse segredo é uma pessoa íntegra e não nos exporá ao ridículo ou nos irá humilhar frente a nossa fraqueza, esta confiança emerge dos sentimentos de ligação, segurança, intimidade, respeito no ser humano (p.193).

Os estudantes, ao registrarem imagens de pacientes (com ou sem consentimento) e veiculá-las em redes sociais estariam violando esta confiança. No contexto de instituições como hospitais universitários, muitos pacientes são pessoas carentes e passivamente se submetem a condições que não gostariam por medo de não serem mais atendidas. Acrescenta-se a isto que, em tempos de redes sociais, o sujeito pode consentir com a captura da imagem ou vídeo, porém não deixar claro se permitiria o compartilhamento em mídias, podendo concordar ou não com a exposição. Então cabe inquirir aos estudantes, método adotado na presente pesquisa, a respeito do tipo de consideração moral que dão a relação com um paciente ou usuário de sistema de saúde. As respostas a este questionamento certamente são permeadas por diferentes concepções de vulnerabilidade, de autonomia reduzida e de paternalismo, que permitem uma reflexão bioética.

Há poucos estudos sobre privacidade, confidencialidade e bioética no Brasil 95, 98-108, desta forma, conhecer a percepção ética de estudantes da área de saúde sobre o uso das imagens e/ou vídeos bem como informações de pacientes e sua exposição em meios sociais e discutir à luz da Declaração Universal sobre Bioética e Direitos Humanos, é um exercício que permitirá uma reflexão sobre a formação em bioética dos estudantes de saúde. 


\section{REVISÃO BIBLIOGRÁFICA}

\subsection{OS CONCEITOS DE PRIVACIDADE E DE CONFIDENCIALIDADE}

O sociólogo Zigmunt Bauman traz em suas obras reflexões sobre a modernidade, o modo de agir da sociedade e de cada pessoa em particular. Em muitas de suas reflexões elabora metáforas e analogias para permitir uma compreensão do momento atual da sociedade. Os líquidos e sua fluidez são sua metáfora mais frequente:

Os líquidos, uma variedade dos fluidos, devem essas notáveis qualidades ao fato de que suas "moléculas são mantidas num arranjo ordenado que atinge apenas poucos diâmetros moleculares", enquanto "a variedade de comportamentos exibida pelos sólidos é um resultado direto do tipo de liga que une os seus átomos e com arranjos estruturais destes". "Liga", por sua vez, é um termo que indica a estabilidade dos sólidos - a resistência que eles "opõem à separação dos átomos(p.7-8). ${ }^{50}$

Em suas obras discorre sobre o fato de que os fluidos possuem incrível mobilidade, capacidade de mover com facilidade, escorrer, fluir, respingar, transbordar, vazar, pingar, podem ser filtrados, destilados. Situação que não ocorre facilmente com os sólidos. Esses são aspectos que Bauman transmuta para a sociedade em que vivemos, e esclarece que:

Os sólidos que estão para ser lançados no cadinho e os que estão derretendo neste momento, o momento da modernidade fluída, são os elos que entrelaçam as escolhas individuais em projetos e ações coletivas - os padrões de comunicação e coordenação entre as políticas de vida conduzidas individualmente, de um lado, e as ações políticas de coletividades humanas de outro (p.12)

Bauman, ao citar entrevista de Ulrich Beck, fala da ação da modernidade sobre ela mesma, uma espécie de "modernização da modernidade", em que os valores iluministas são postos em xeque. Castiel ${ }^{109}$, ao discutir temas da atualidade, como a comunicação e a percepção de insegurança, se vale também dos conceitos de Bauman dizendo que:

Bauman analisa aspectos relacionados às novas características do mundo do trabalho no âmbito da chamada 'modernidade líquida'. Mais especificamente, ressalta a tenuidade dos vínculos humanos nesse contexto e assinala que um dos traços marcantes nas condições de vida contemporâneas (referindo-se especialmente às regiões mais 
prósperas e tecnologicamente avançadas do mundo) recebe algumas tentativas de designar tal fenômeno: precariedade, instabilidade, vulnerabilidade. "O fenômeno que todos esses conceitos tentam captar e articular é a experiência combinada da falta de garantias (de posição, títulos e sobrevivência), da incerteza (em relação à sua continuação e estabilidade futura) e de insegurança (do corpo, do eu e de suas extensões: posses, vizinhança, comunidade)"(p.162).

Castiel acrescenta-se que as conjunturas contemporâneas são caracterizadas por mudanças socioculturais velozes. Tornando se perceptível às consequências das exacerbadas mutações da percepção de tempo e espaço sobre os seres humanos, adicionadas à glorificação do "consumismo e do individualismo". Em que mais e mais os produtos ofertados ao consumo passam a operar como "precárias matrizes de identidade". A excessiva oferta potencializa a desordenação, a fragmentação e o estranhamento. "Em suma, as fontes instauradoras de solidez às identidades se fragilizaram de modo significativo. Com isto, a segurança ontológica está se volatilizando a olhos vistos" ${ }^{109}$.

Os pensamentos de Bauman \& Castiel coadunam-se ao expressarem que a conduta dos seres humanos tem sido pautadas em características e valores do mercado do consumo, que não tem uma forma e ao mesmo tempo tem todas as formas, que se moldam conforme o momento. É pautado nessa "ordem" que as pessoas constroem suas vidas e fundamentam suas condutas, identidades e privacidade.

Bauman, em Sociedade Individualizada ${ }^{110}$, faz um exercício de reflexão sobre como a sociedade contemporânea elabora sua privacidade:

Como observou Peter Ustinov, espirituoso humorista inglês, "Este é um país livre, madame. Temos o direito de compartilhar sua privacidade em um espaço público". Alain Ehrenberg, sociólogo francês, escolheu uma noite de quarta-feira, em outubro de 1983, como momento decisivo na história cultural francesa (e não apenas dela): naquela noite, uma certa Vivianne, na frente de milhões de telespectadores, anunciou que seu marido, Michel, sofria de ejaculação precoce e que ela nunca tivera prazer em suas relações sexuais (...) O "privado" invadiu a cena-destinada-a-ser-pública, mas não para interagir com o "público". Mesmo quando está sendo enxovalhado na frente do público, o "privado" não adquire urna nova qualidade; quando muito, é reforçado em sua privacidade. As conversas televisadas de "pessoas comuns", como Vivianne e Michel, e o mexerico "exclusivo" dos jornais sobre as vidas privadas de estrelas do mundo do espetáculo, políticos e outras celebridades são lições públicas sobre a vacuidade da vida privada e a vaidade das 
esperanças investidas em alguma coisa menos particular do que os problemas privados e as curas privadas(p.256).

Este acontecimento parece indicar, ainda que tenha ocorrido antes da era da informática, como se dariam os arranjos atuais acerca de identidade e individualidade. O espaço público, ilusório virtual, para parecer que somos mais do que realmente somos. Dupas confirma essa realidade quando enfatiza que:

De fato, a vida nas sociedades contemporâneas se apresenta como uma imensa acumulação de espetáculos. Tudo que era vivido diretamente torna se uma representação. (..) O espetáculo constitui o modelo atual da vida dominante na sociedade. A primeira fase da dominação da economia sobre a vida social acarretou uma degradação do "ser" para o "ter". Em seguida, operou-se um deslizamento generalizado do "ter" para o "parecer-ter". Na atual situação das grandes massas excluídas da sociedade global só resta o "identificar-se-com-quem-parece-ser-ou-ter" por meio do espetáculo, sequer ao vivo, mas "visto-a-distância" através das mídias globais que Ihes oferecem exibições instantâneas de todos os tipos e partes do mundo (p.52). ${ }^{111}$

Este é o background ético e social do presente trabalho; um período histórico em que há um conflito sobre os limites da intervenção sobre o corpo, a mente, a saúde e o futuro, ao mesmo tempo em que, para dar uma resposta à alienação a qual nos sujeitamos no mundo concreto, intentamos encontrar no mundo virtual as válvulas de escape. Paradoxalmente, o mundo virtual, que seria de constituição libertária, tem sido afetado pelas mesmas mazelas do mundo concreto: jogos de poder, violência, violação de direitos, vigilância panóptica. É neste contexto que as questões de privacidade serão aqui discutidas: da formulação tradicional em bioética até a questão da interface digital.

Os textos mais tradicionais em bioética como no caso de Francisconi \& Goldim ${ }^{96}$ definem privacidade como:

a limitação do acesso às informações de uma dada pessoa, bem como do acesso à própria pessoa e à sua intimidade. É a preservação do anonimato e dos segredos. É o respeito ao direito de o indivíduo manter-se afastado ou permanecer só(p.272).

Cabe esclarecer que no presente trabalho somente será abordado o tema do direito à privacidade no cuidado de saúde. Não serão abordados elementos de privacidade em pesquisas clínicas, privacidade de dados genéticos e gametas, 
privacidade na doação de órgãos ou a questão da defesa do direito ao aborto como direito à privacidade do corpo ${ }^{112-114}$.

A concepção de privacidade parece oscilar entre uma concepção de valor moral ou de direito legal. É o agir soberano e autônomo de um indívido sobre sua própria identidade, sobre seu corpo e sobre qualquer aspecto de sua vida privada. Segundo a Encyclopedia of Bioethics, ${ }^{115}$ Privacidade é um direito relacionado com quatro dimensões da experiência humana, a saber: física (physical privacy), informacional (informational privacy), proprietária (proprietary privacy) e decisória (decisional privacy) (p. 2120).

A privacidade física é compreendida como a liberdade de não querer ter contato com outras pessoas. Allen ${ }^{115,116}$, no entanto, salienta que:

Complete physical privacy is inconsistent with the demands of modern healthcare. The modern delivery of health services presupposes that patients and medical professionals mutually accept nudity, touching, and observation as unavoidable aspects of examination, treatment, surgery, and hospitalization. ${ }^{(i)}$

A privacidade informacional é definida como a proteção de dados pessoais e registros em prontuários:

(...) secrecy, confidentiality, data protection, or anonymity. It requires limits on the accessibility of personal information. Informational privacy concerns in the healthcare setting have traditionally focused on the confidentiality of the physician-patient relationship and on limiting access to medical and insurance records. ${ }^{115}$ (ii)

Segundo Luciano \& colaboradores ${ }^{117}$, deve-se compreender que a privacidade é ligada, no contexto de instituições de saúde, ao sigilo de dados, quer sejam contidos em prontuários médicos ou na informação de serviço que transita oralmente entre profissionais. É a conduta dos trabalhadores em saúde que assegura cotidianamente o sigilo de tais informações. A privacidade, no que tange a conduta, consiste em decidir com prudência o que falar, para quem falar e onde

\footnotetext{
i A privacidade física completa é incompatível com as exigências do cuidado em saúde moderno. A moderna prestação de serviços de saúde pressupõe que os pacientes e os profissionais médicos aceitam mutuamente nudez, contato físico e observação, assim como aspectos inevitáveis de exames, tratamentos , cirurgias e internação.

ii (...) sigilo, confidencialidade, proteção de dados, ou anonimato. Ela exige limites sobre a acessibilidade de informações pessoais, preocupações com a privacidade informativos nos cuidados de saúde têm tradicionalmente focada na confidencialidade da relação médico- paciente e na limitação do acesso a registros médicos e de seguros
} 
falar, visto que tais profissionais possuem autorização de acesso a certos dados, podendo, inadvertidamente, discuti-los em ambiente inapropriados, e com isso, transmiti-los a outros indivíduos, caracterizando assim, vazão de informações restritas de seus pacientes.

Ainda segundo Allen, a privacidade proprietária diz respeito aos impedimentos legais e éticos para apropriação, por terceiros, de um repositório de identidade pessoal, como, por exemplo, uma fotografia, uma gravação de audio, um exame por imagem ou mesmo dados de exames laboratoriais ou material genético ${ }^{115}$.

Por fim, Allen ${ }^{115}$ apresenta o conceito de privacidade decisória, que denota escolhas autônomas sobre os assuntos pessoais e íntimos que constituem as vidas privadas. Esta última definição se aproxima do respeito pela autonomia. $O$ significado de autonomia, na área de saúde, refere se a capacidade de o usuário tomar decisões em escolher o profissional para seu atendimento, bem como a definição da terapêutica a receber ou admitir, tendo em vista a sua crença ou não. Assim, estabelecendo seus interesses de forma livre. A autonomia se torna fundamentada no "respeito à pessoa humana, à individualidade, implicando o direito à escolha e à manifestação de vontade"(p.102). Nesse sentido as escolhas de todo ser humano decorre do exercício de sua autodeterminação, e outrem não possui direito de impor sua vontade ${ }^{118}$.

Como afirmado na introdução, as concepções de respeito à privacidade e confidencialidade fazem parte das principais normas internacionais em bioética, entre as quais a Declaração Internacional sobre os Dados Genéticos Humanos, que não será alvo de avaliação, e Declaração Universal sobre Bioética e Direitos Humanos, a qual será abordada em tópico específico por trazer conceitos e fundamentos de respeito à pessoa humana, à autonomia, e ao sigilo dos dados, das informações e das imagens dos indivíduos em sua plenitude, além de outros princípios que não serão abordados neste estudo.

Também é importante aportar que no que tange ao respeito à privacidade, há a constante tensão entre 0 direito a confidencialidade e 0 dever de confidencialidade. Esta tensão é o encontro de duas (ou mais) autodeterminações, a do profissional e a do paciente, que se implicam num trânsito de informações, sentimentos e intervenções visando o cuidado em saúde. Neste contexto, há o encontro da vida privada do paciente (e a do profissional de saúde) com a vida pública dentro de uma unidade de saúde que pode implicar em estranhamentos 
morais. O paciente e o médico, quer sejam próximos, quer sejam estranhos morais, estabelecem uma relação de confiança que se justifica pela manutenção e sucesso da relação terapêutica e da garantia de funcionamento de todo aparelho terapêutico (unidade de saúde ou hospital) ${ }^{119}$.

Em qualquer instituição terapêutica o paciente é registrado e identificado, sendo sua condição "conhecida" pelos profissionais que ali trabalham, mas também é possível verificar que, apesar da possibilidade de rastreamento, existem mecanismos de anonimização ou desidentificação, como, por exemplo, a numeração atribuída a exames laboratoriais, visando preservar a privacidade do paciente frente a setores que somente indiretamente lhe prestam serviços ${ }^{120}$.

Apesar das normas institucionais e das prescrições deontológicas, é preciso lembrar que avanço cientifico e tecnológico decorrente do contemporâneo "processo de globalização" e de ampliação do acesso à internet suscitaram intensas transformações comportamentais, afetando as concepções de privacidade entre profissionais de saúde, familiares de pacientes e dos próprios pacientes. A internet, ao encurtar a relação tempo-espaço, apresentou-se como solução que diminuiu as distâncias comunicacionais entre indivíduos e grupos sociais. Enviar uma informação (texto, foto, som ou vídeo) acerca do estado de saúde de um parente ou paciente evita deslocamentos de pessoas. O médico pode remotamente acompanhar seu paciente e amigos e parentes têm um fluxo contínuo de notícias.

A tecnologia móvel também possibilita uma "zona de nebulosidade moral". O filósofo francês Baudrillard ${ }^{121}$ afirma que criamos um duplo virtual performático, isto é, projeta-se, nas redes sociais simulacros daquilo que são os profissionais de saúde ou as pessoas. Trata-se de avatares que representam elementos que nunca existiram ou que não possuem mais o seu equivalente na realidade. $E$ a rede social na internet seria a simulação, que é a imitação de uma operação ou processo existente no mundo real ${ }^{122}$. Neste espaço simulado, os avatares ganham liberdade transgressora, que pode ser utilizada para o bem ou para o mal. Infelizmente, parece haver uma tendência por parte dos usuários de redes sociais à violência e a perversidade, como por exemplo o ciberbullying, a cybervingança e outras modalidade de agressão ou violação de direitos ${ }^{92,123-127 .}$

Os aspectos de violência ou de violação supracitados podem alcançar dimensão mundial quase que instantaneamente e ter maiores consequências que no mundo concreto. O simulacro do ato violento pode aparecer camuflado nas 
impensadas ou propositadas "curtidas" nas redes sociais, conformando uma violência simulada, que nada mais é uma propagação de violência. A violência de fotografar um paciente sem consentimento, se converte na violência da exposição de uma imagem sem permissão, que por sua vez se converte na violência dos olhares não permitidos sobre a intimidade, e por assim em diante. A natureza da rede é complexa e não linear. Uma foto, rapidamente é copiada em dezenas de milhares ou milhões de computadores de todo mundo. Apagar este registro é praticamente impossível dada a veloz capacidade transformação tecnológica e social daquela imagem inicial. Por isso, hoje se fala em direito ao esquecimento ${ }^{128}$, isto é, no direito a ter um registro digital apagado no espaço simulado da internet.

Este panorama complexo denota a necessidade de garantir proteção jurídica e normatização de condutas humanas nestes espaços. No âmbito da universidade, se torna necessário criar uma base consistente de formação do profissional de saúde - em bioética - e ofertar educação continuada para uma nova forma de cidadania digital.

Mas ainda que haja norma, o vazamento de informações, imagens e vídeos de pacientes é potencializado pela ampla e acessível disponibilidade das tecnologias, e o modo como seus usuários se comportam frente aos seus sistemas vulneráveis. Por intenção ou por negligência, os profissionais de saúde se apropriaram destas novas tecnologias de comunicação móvel e as utilizam no dia-adia, em momentos e de forma não convenientes ao ambiente de atendimento em saúde. Este é um fato inevitável. Desta forma, além de discutir a questão da privacidade, torna-se necessário compreender o que é confidencialidade.

A confidencialidade é um princípio deontológico, também conhecido como segredo ou sigilo médico. Apesar de autores como Francisconi \& Goldim ${ }^{96}$ afirmarem que há diferenças entre os termos, para fins desta dissertação, adotar-seá ambos indistintamente ${ }^{(i i i)}$.

Segundo Hottis \& Parizeau"129, a confidencialidade é norma que "impõe a obrigação de discrição a qualquer indivíduo depositário, pelas suas funções, das informações que Ihe são confiadas”. Segundo os autores, esta obrigação abrange também fatos que são descobertos durante o atendimento de saúde ${ }^{129}$. Portanto, a

\footnotetext{
iii Para os autores, a expressão segredo pode ser entendida como uma ocultação qualquer, ou preservação de informações, e está mais relacionada a intimidade do indivíduo; enquanto sigilo tem sido empregado com caráter mais de ocultação do que de proteção.
} 
confidencialidade pode ser entendida como o direito de não divulgação ou ainda a garantia de que informação identificável seja conservada longe do alcance dos outros.

Nos campos da odontologia e da medicina estética é frequente a veiculação de imagens de partes do corpo que não permitem a identificação do indivíduo, salvo por ele mesmo ou por alguém muito próximo. Nestas situações pode haver constrangimento individual, mesmo que a figura pública da pessoa tenha sido anonimizada: um sorriso antes e depois de uma intervenção, um seio antes ou depois de cirurgia plástica. Ainda que sejam partes do corpo, sua divulgação sem consentimento pode remeter o indivíduo a sofrimento psíquico, apesar de que na contemporaneidade, as pessoas queiram e busquem a exposição...

A Organização Mundial da Saúde e o Council for International Organizations of Medical Sciences (CIOMS) declaram, em seus documentos, que todos os dados a respeito de uma pessoa que permitam sua identificação, e que estejam registrados (anotados, automatizados, visual, áudio) ou tão somente, guardados na lembrança dos profissionais de saúde, estão subordinado a obrigação de confidencilidade ${ }^{130}$.

No Brasil, o Conselho Federal de Medicina - CFM por meio da Resolução № 1931/2009 (Código de Ética Médica) ${ }^{\text {iv }}$, capítulo IX artigo 73, aborda a questão do sigilo, como forma de garantir a privacidade do paciente. Decreta que: "É vedado ao médico: Revelar fato de que tenha conhecimento em virtude do exercício de sua profissão, salvo por motivo justo, dever legal ou consentimento, por escrito, do paciente".

Loch $^{131}$ acrescenta que, no século XX, principalmente depois da Segunda Guerra Mundial, as reivindicações pelos Direitos Humanos fizeram surgir novas expectativas em relação ao sigilo na medicina. Recorda que em documentos internacionais, como a Declaração Universal dos Direitos Humanos de 1948, se explicita que não deve haver intromissão na vida particular ou familiar das pessoas. Nesse contexto, o sigilo é definido como "uma proteção contra a divulgação não autorizada de informações, que estabelece, demarca e fortalece as fronteiras da privacidade"(p.40) ${ }^{86}$.

Seoane e Fortes ${ }^{99}$ afirmam que o significado clássico de confidencialidade também é explicitado no Glossário de Bioética do Instituto Kennedy de Ética: a

\footnotetext{
${ }^{\text {iv }}$ Resolução CFM no 2.126/2015 (Publicado no D.O.U., 01 de outubro de 2015, Seção I, p. 131). Dispovível: http://www.portalmedico.org.br/resolucoes/CFM/2015/2126_2015.pdf
} 
confidencialidade está pautada em garantir que informações fornecidas de forma pessoal, em regime de confiança, não sejam reveladas sem autorização e sejam protegidas. Cohen ${ }^{132}$ afirma, em relação aos segredos profissionais, que há dois conflitos éticos diferentes em meio às instituições de saúde: o do segredo na relação profissional-paciente e o segredo na interação das pessoas com a instituição de saúde.

Parece haver consonância de diversos autores acerca do significado de sigilo. Pode-se afirmar que há um conjunto de disposições deontológicas que envolvem a confidencialidade $^{129}$, a saber:

a) Deve ser respeitado o segredo sobre qualquer informação de natureza confidencial obtida no exercício de uma função profissional.

b) A liberação do segredo médico só é autorizada com o consentimento da pessoa interessada ou quando a lei assim ordenar.

c) O pedido de revelação das informações de natureza confidencial bem como a autorização no sentido de que tais informações sejam confiadas exigem que a pessoa interessada esteja plenamente informada da finalidade do pedido e das diversas utilizações que podem ser dadas a essas informações.

d) A menos que a natureza do caso o exija, é proibido revelar que uma pessoa recorreu a serviços sociais e de saúde.

e) Devem ser evitadas as conversas indiscretas acerca de uma pessoa e dos serviços que the foram prestados.

f) É proibido o uso de informação de natureza confidencial em prejuízo de uma pessoa ou tendo em vista a obtenção directa ou indirecta de um benefício pessoal ou destinado a outrem.

g) Numa relação de prestação de cuidados, o segredo não é oponível à pessoa. Nesta matéria, prima o direito à verdade.

Há um paradigmático caso, muito utilizado em aulas de bioética, o caso Tarassof ${ }^{133}$, que deu origem a possibilidade de derrogação do segredo médico ${ }^{96}$ em três circunstâncias:

a) Um sério dano físico a uma pessoa identificável e específica tiver alta probabilidade de ocorrer (não-maleficência);

b) Um benefício real resultar desta quebra de confidencialidade (beneficência);

c) For o último recurso, após ter sido utilizada a persuasão ou outras abordagens (autonomia).

Frente a situações em que o sigilo se torne passível de violação, a prudência é aconselhada ao médico, que precisará compreender "bem os aspectos psicodinâmicos" entremeados no caso, e debater abertamente com a família ou com 
o paciente, em conformidade com a situação, para depois decidir-se, visto ser uma ação muito séria: "enganar deliberadamente a alguém(p.271)"96.

Naves ${ }^{134}$, fazendo uma reflexão sobre o sigilo em tempos de internet, afirma:

Deve ser enfatizada a necessidade da vedação quanto à divulgação
de imagens de pacientes na internet, inclusive de pessoas públicas e
famosas, lembrando-se que tal fato incorre em quebra do sigilo
médico, caracterizando sensacionalismo. A preservação do sigilo
médico deve ser mantida, devendo ser evitada a transmissão online
de atos médicos, cirurgias e consultas. O médico precisa entender
que as informações constantes em um site devem ter como
finalidade a educação e o esclarecimento da coletividade. O
sensacionalismo com a divulgação de "melhores equipamentos" e os
"mais modernos" deve ser evitado. Cautela deve ser tomada quanto
à utilização de sites patrocinados por indústria farmacêutica e/ou
empresa de equipamentos médicos (p.192).

Além da prudência, é importante ressaltar a questão da vulnerabilidade de pacientes nestas situações. Compreende-se vulnerabilidade como uma conjuntura em que certas pessoas se encontram em condições diminuídas de resguardar seus interesses ou estar em maior probabilidade de sofrer exploração ${ }^{130}$. Estas circunstâncias têm estado vinculada a condição corporal, financeiras, educacional ou situação social específica. Alguns grupos de pacientes são comumente avaliados como mais vulneráveis, como por exemplo: crianças, deficientes, doentes em estado terminal e pessoas com doença mental.

Assim, em muitas situações cotidianas no processo de cuidados de saúde, a autonomia fica comprometida pelo estado potencializado de vulnerabilidade do paciente (doente e dependente de ajuda) frente ao seu atendente. Estas pessoas são impossibilitadas de autodeterminarem os limites do privado e confidencial, por isso carecem de maior proteção.

\subsection{PRIVACIDADE DIGITAL E COMPORTAMENTO DE PROFISSIONAIS DE SAÚDE}

Nos últimos anos têm surgido indícios de que há necessidade de se estudar os comportamentos de estudantes e estagiários, da área de saúde, frente ao uso das novas tecnologias no âmbito do cuidado em saúde, tendo em vista que determinadas condutas têm potencial de comprometer a qualidade da relação 
profissional de saúde-paciente e com isso, podendo haver transgressão dos direitos dos pacientes. Também vale lembrar (apesar de não ser o foco deste estudo) a importância da relação profissional-profissional e também com suas categorias profissionais para um respeito mútuo e o bom serviço prestado a sociedade.

Martorell e colaboradores ${ }^{36}$, no período de agosto a setembro de 2013, selecionaram imagens que já haviam sido publicadas e estavam registradas nos "álbuns" de 17 profissionais de saúde, sendo doze cirurgiões-dentistas e cinco médicos, totalizando trinta e nove imagens selecionadas, nas quais vinte e sete foram divulgadas por cirurgiões-dentistas e doze por médicos. No final da coleta dos dados, foi percebido expressiva participação de internautas, com um total de 800 "curtidas" e 310 comentários.

O estudo notifica que das imagens divulgadas foi possível identificar diretamente as pessoas envolvidas em boa parte das fotos e em outras; foi possível ver o rosto. Identificaram vários comentários de internautas que zombaram ou ridicularizam os pacientes, como no caso de uma foto onde mostra o sorriso de uma paciente com "bigodes", para a qual havia várias sugestões maldosas. Tirando um ou outro comentário de indignação, a maioria das manifestações era de deboche, ridicularização e diminuição dos pacientes. Baseado nessas informações, os pesquisadores enfatizam que os profissionais de saúde necessitam respeitar a confidencialidade e privacidade do paciente, sobretudo quando se trata de publicações que queiram partilhar em suas redes sociais, e jamais publicarem aquelas nas quais dados de terceiros possam ser identificados ou simplesmente os que o paciente não queira.

Em agosto de 2014, foi noticiada matéria jornalística ${ }^{135}$ tratando da divulgação de imagem de paciente em redes sociais, feitas por médicos do hospital das Forças Armadas do Distrito Federal-DF. Em uma das imagens, postada por uma oftalmologista, mostrava-se as pálpebras inchadas de um paciente que passou por uma cirurgia de correção (blefaroplastia). Já na segunda imagem, mostra-se o olho e as ferramentas usadas durante uma exérese de pterígio - procedimento para retirar uma membrana de cor rosada que cresce invadindo a córnea; a imagem, aparentemente, parece ter sido feita por uma residente que assistia, a qual tinha também outras imagens do ambiente de saúde em sua rede social. A jornalista Miranda também relata que havia os chamados "selfies"- autorretratos, em que uma moça e dois rapazes fazem referência a passar o carnaval no hospital, e a outra, 
com hashtag de um rapaz com trajes de ambiente aparentemente cirúrgico, em mais de uma postagem.

Jornalistas têm denunciado que profissionais de saúde frequentemente têm exposto suas rotinas de trabalho em redes sociais e consequentemente acabam colocando imagens de pacientes em situações que podem causar constrangimento, ou que desrespeitem a autonomia e a dignidade humana das pessoas. Usam aplicativos de relacionamento, como o Tinder ${ }^{r}$, para divulgar fotos com trajes do ambiente hospitalar, e consequentemente expõem também os pacientes, que podem ser identificados.

Devido ao acesso fácil aos conteúdos na internet, terceiros não proprietários de imagens e nem dos direitos autorais, podem fazer republicações sem autorização, o que tem deixado até os magistrados com "muitas dúvidas em relação aos conflitos paradoxais entre a proteção dos direitos personalíssimos e o direito à liberdade de informação e manifestação do pensamento". Como equacionar? Quais seriam os limites $?^{136}$

Conforme Gonçalves e Verdi ${ }^{136}$, as clinicas-escola têm no seu cotidiano algumas situações típicas que podem ter o potencial de aumentar "problemas e conflitos que normalmente fazem parte da rotina de instituições que prestam atendimento de saúde à população por meio de estudantes"(p.756). Isso ocorre devido os indivíduos serem colocados na condição de objeto de estudo, ainda que provisoriamente; porém, isso não significa necessariamente violar princípios éticos de relacionamento, desde que os pacientes sejam esclarecidos de que se trata de 'instituições de ensino', que os mesmos não sejam expostos a riscos sem necessidade, que tenha e sejam exercidas e respeitadas normas rigorosas "quanto aos princípios do respeito à autonomia do paciente e da confidencialidade das informações obtidas durante o tratamento"(p.756). A questão ética a se avaliar nessa relação paciente-aluno-professor é se não há supremacia de um interesse em desfavor do outro. Também, deve-se levar em consideração a questão da vulnerabilidade social dos indivíduos, que tradicionalmente frequentam as instituições que prestam atendimento-ensino-aprendizagem, que pela necessidade aceitam o que lhes é solicitado, e assim serem mais propensos a terem seus direitos desrespeitados.

\footnotetext{
${ }^{\vee}$ O Tinder é aplicativo para celulares que funciona como um catálogo de encontros, mostrando quem está nas imediações do usuário.
} 


\subsection{ASPECTOS JURÍDICOS DE PROTEÇÃO E NORMAS}

No Brasil, ainda não há lei específica para garantir os direitos dos pacientes em terem resguardadas todas as nuances do processo de cuidados profissional de saúde- paciente, frente às tecnologias móveis. Até então, esse processo conta apenas com a normatização de Códigos de Ética profissionais que têm empenhado em adequarem-se aos avanços tecnológicos. Há também algumas leis não específicas para o assunto, que versam sobre alguns direitos dos indivíduos como, por exemplo, o Marco Civil da Internet, o Código Penal e o Código Civil, bem como o Estatuto da criança e do adolescente que expressam firmemente o direito de proteção de dados e informações privadas dos indivíduos.

O Marco Civil da Internet ${ }^{\text {vi }}$ regula o uso da Internet no Brasil, por meio da previsão de princípios, garantias, direitos e deveres para quem usa a rede, bem como da determinação de diretrizes para a atuação do Estado. Em seu artigo $8^{\circ}$ estabelece: "A garantia do direito à privacidade e à liberdade de expressão nas comunicações é condição para o pleno exercício do direito de acesso à internet".

O Código Civil Brasileiro (Lei 10.406/2002) ao versar sobre os direitos à personalidade traz em seu Artigo 20, proibições e condições para uso de imagem e informações de pessoas por terceiros como:

Salvo se autorizadas, ou se necessárias à administração da justiça ou à manutenção da ordem pública, a divulgação de escritos, a transmissão da palavra, ou a publicação, a exposição ou a utilização da imagem de uma pessoa poderão ser proibidas, a seu requerimento e sem prejuízo da indenização que couber, se the atingirem a honra, a boa fama ou a respeitabilidade, ou se se destinarem a fins comerciais.

Ainda em seu Artigo 21 o Código Civil estabelece que " $A$ vida privada da pessoa natural é inviolável, e o juiz, a requerimento do interessado, adotará as providências necessárias para impedir ou fazer cessar ato contrário a esta norma".

O Estatuto da Criança e Adolescente ${ }^{137}$, em seus artigos 17 e 18, estabelece que crianças e adolescentes têm direito a inviolabilidade da integridade física, psíquica e moral, bem como preservação da imagem, da identidade, da autonomia, dos valores, ideias e crenças, dos espaços e objetos pessoais. Circunscreve ainda

\footnotetext{
${ }^{\text {vi }}$ LEI N ${ }^{\circ}$ 12.965, DE 23 DE ABRIL DE 2014. Disponível em http://www.planalto.gov.br/ccivil_03/_ato2011-
} 2014/2014/lei/112965.htm 
que todas as pessoas têm o dever de zelar para garantir a "dignidade da criança e do adolescente, pondo-os a salvo de qualquer tratamento desumano, violento, aterrorizante, vexatório ou constrangedor" ${ }^{137}$.

Em caráter infra legal, o Conselho Federal de Medicina (CFM) preocupado com o avanço das mídias sociais e a grande exposição de temas médicos em ambientes virtuais, criou a Resolução no 2.126/2015, que constitui os parâmetros para a publicidade na área médica, "conceituando os anúncios, a divulgação de assuntos médicos, o sensacionalismo, a autopromoção e as proibições referentes à matéria", define expressamente que:

Art. $2^{\circ} \mathrm{O}$ artigo 13 da Resolução CFM ํㅜ 1.974/11 passa vigorar com a seguinte redação:

Art. 13 As mídias sociais dos médicos e dos estabelecimentos assistenciais em Medicina deverão obedecer à lei, às resoluções normativas e ao Manual da Comissão de Divulgação de Assuntos Médicos (Codame)

$\S 1^{\circ}$ Para efeitos de aplicação desta Resolução, são consideradas mídias sociais: sites, blogs, Facebook, Twiter, Instagram, YouTube, WhatsApp e similares.

$\S 2^{\circ}$ É vedada a publicação nas mídias sociais de autorretrato (selfie), imagens e/ou áudios que caracterizem sensacionalismo, autopromoção ou concorrência desleal.

$\S 3$ ํ É vedado ao médico e aos estabelecimentos de assistência médica a publicação de imagens do "antes e depois" de procedimentos, conforme previsto na alínea "g" do artigo $3^{\circ}$ da Resolução CFM no 1.974/11.

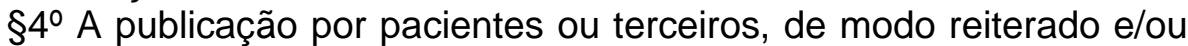
sistemático, de imagens mostrando o "antes e depois" ou de elogios a técnicas e resultados de procedimentos nas mídias sociais deve ser investigada pelos Conselhos Regionais de Medicina (p.131). vii

O Conselho Federal de Enfermagem, publicou a Resolução no 311/2007, determinando em seu artigo 19 que a equipe de enfermagem tem o dever de: "respeitar o pudor, a privacidade e a intimidade do ser humano, em todo seu ciclo vital, inclusive nas situações de morte e pós-morte". Acrescenta no capítulo que trata do sigilo profissional, que é proibido ao enfermeiro:

Art. 84 - Franquear o acesso a informações e documentos para pessoas que não estão diretamente envolvidas na prestação da assistência, exceto nos casos previstos na legislação vigente ou por ordem judicial

\footnotetext{
${ }^{\text {vii }}$ Resolução CFM n ${ }^{\circ}$ 2.126/2015 (Publicado no D.O.U., 01 de outubro de 2015, Seção I, p. 131). Dispovível: http://www.portalmedico.org.br/resolucoes/CFM/2015/2126_2015.pdf
} 
Art. 85 - Divulgar ou fazer referência a casos, situações ou fatos de forma que os envolvidos possam ser identificados ${ }^{\text {viii }}$

Também o Código de Ética Odontológicaix traz em seu capítulo VI, referente ao sigilo profissional, o Artigo 14, determinando o que se compõe infração ética:

I - revelar, sem justa causa, fato sigiloso de que tenha conhecimento em razão do exercício de sua profissão;

II - negligenciar na orientação de seus colaboradores quanto ao sigilo profissional; e,

III - fazer referência a casos clínicos identificáveis, exibir paciente, sua imagem ou qualquer outro elemento que o identifique, em qualquer meio de comunicação ou sob qualquer pretexto, salvo se o cirurgião-dentista estiver no exercício da docência ou em publicações científicas, nos quais, a autorização do paciente ou seu responsável legal, Ihe permite a exibição da imagem ou prontuários com finalidade didático-acadêmicas (..)

III- publicar, sem autorização por escrito, elemento que identifique o paciente preservando a sua privacidade(p.7).

Em outras áreas da saúde, como a Fisioterapia ${ }^{x}$, também há atualização no sentido de adequá-lo ao contexto das tecnologias móveis. A Resolução №424/2013 traz proibição expressa no parágrafo $\mathrm{V}$ do artigo 15:

Inserir em anúncio ou divulgação profissional, bem como expor em seu local de atendimento/trabalho, nome, iniciais de nomes, endereço, fotografia, inclusive aquelas que comparam quadros anteriores e posteriores ao tratamento realizado, ou qualquer outra referência que possibilite a identificação de cliente/paciente/usuário, salvo para divulgação em comunicações e eventos de cunho acadêmico científico, com a autorização formal prévia do cliente/paciente/usuário ou do responsável legal.

\subsection{A DECLARAÇÃO UNIVERSAL SOBRE BIOÉTICA E DIREITOS HUMANOS}

Em 2005, mais de 90 países se reuniram na sede da Organização das Nações Unidas para a Educação, Ciência e Cultura(UNESCO) com objetivo de definir o texto final da Declaração Universal sobre Bioética e Direitos Humanos - DUBDH ${ }^{47}$. Neste

\footnotetext{
viii Conselho Federal de Enfermagem. Resolução COFEN-311/2007. Aprova a reformulação do código de ética dos profissionais de Enfermagem [Internet]. Diário Oficial da República Federativa do Brasil, Brasília (DF); 2007 Fev 8; Seção IV, Artigo84, 85. [citado 2015 Jul 10]. Disponível em: http://se.corens.portalcofen.gov.br/codigo-de-etica-resolucao-cofen-3112007

${ }^{\text {ix }}$ Conselho Federal de Odontologia. Código de Ética Odontológica, Aprovado pela Resolução CFO-118/2012. Disponível em: http://cfo.org.br/wp-content/uploads/2009/09/codigo_etica.pdf

${ }^{x}$ COFITO.Resolução No424, de 08 de julho de 2013. (D.O.U. n ${ }^{\circ}$ 147, Seção 1 de 01/08/2013). Disponível em: http://www.coffito.org.br/site/index.php/home/resolucoes-coffito/503-resolucao-n-424-de-08-de-julho-de-2013estabelece-o-codigo-de-etica-e-deontologia-da-fisioterapia.html
} 
contexto havia marcadamente a divisão entre países pobres, e países ricos, em que estes últimos defendiam um documento que restringia a bioética ao contexto biotecnológico e biomédico, enquanto o Brasil, com o apoio das delegações latinoamericanas, defendeu e conseguiu ampliar a temática para os campos sanitários, social e ambiental ${ }^{138}$. Este movimento, possibilitou que a agenda bioética do século XXI se constituísse mais aplicada e comprometida com as populações vulneráveis e necessitadas. Tornando-se um instrumento a favor da democracia, cidadania e direitos humanos universais ${ }^{139}$.

Caetano \& Garrafa ${ }^{140}$ afirmam que a DUBDH é ferramenta que apoia a reflexão sobre os temas bioéticos considerando seu contexto e assim inclui "o ser humano como agente moral, social, cultural e político"( p.35) na agenda de discussões do século $X X I$.

A DUBDH arrola princípios fundamentais que devem ser respeitados e usados nas tomadas de decisões e nas práticas desenvolvidas por todos aqueles a quem ela é dirigida ${ }^{47}$. Neste estudo especificaremos os seus artigos 3, 4, 5, 6, 7, 8 e 9, que melhor fundamentam a questão ética da temática em estudo, tendo em vista o cenário atual. Também, considerando que, conforme expresso no Artigo 26 da própria $\mathrm{DUBDH}^{47}$, os princípios possuem inter-relação e complementaridade entre si, enfatiza que:

A presente Declaração deve ser considerada em sua totalidade e seus princípios devem ser compreendidos como complementares e inter-relacionados. Cada princípio deve ser interpretado no contexto dos demais, de forma pertinente e adequada a cada circunstância (p.12).

A DUBDH afirma em seu Artigo 3 que a Dignidade Humana e Direitos Humanos e as liberdades fundamentais devem ser totalmente respeitados. Que o bem-estar dos indivíduos é prioridade em relação à ciência e à sociedade ${ }^{47}$. Para Oliveira, o princípio da Dignidade Humana parte do entendimento "de que a dignidade ontológica da pessoa humana foi reconhecida no âmbito do auditório universal, materializado nos debates entre representantes de Estado nas Nações Unidas, e a partir desse momento histórico tornou se um axioma"141(p.14). Ainda conceitua que os Direitos Humanos pela "fundamentação jusnaturalista, são concebidos como direitos naturais, para a historicista, como direitos históricos e para a ética, como direitos morais"(p.42). A dignidade ontológica não depende do valor 
relacional, pode ser determinada como valor que se revela em todo indivíduo pelo fato simples fato de existir.

No panorama regulatório brasileiro, a Resolução do Conselho Nacional de Saúde CNS nำ466 de $2012^{x i}$ foi constituída primando pelo respeito à dignidade humana, proteção às pessoas participantes de pesquisas científicas. Considerando também a eticidade inerente ao desenvolvimento tecnológico e científico, ainda avaliou que tais desenvolvimentos proporcionaram novas percepções da vida e na forma de se viver, englobando além do prolongamento da vida, transformações nos hábitos, cultura e na conduta humana, nos "meios reais e virtuais disponíveis" os quais se modificam e inovam em compasso veloz e ininterrupto.

O artigo 4 da DUBDH trata de Benefício e Dano. Afirma que os benefícios diretos e indiretos aos sujeitos de pesquisa e a pacientes devem ser maximizados nas práticas médicas, juntamente com as associações de tecnologias e os avanços de conhecimento científico, enquanto, os danos devem ser minimizados. Para tanto os benefícios podem ser entendidos como "proveito direto ou indireto, imediato ou posterior, auferido pelo participante e/ou sua comunidade em decorrência de sua participação na pesquisa" 47; quanto à concepção de dano a Resolução CNS nํ466 de 2012 expressa que "dano associado ou decorrente da pesquisa" é "agravo imediato ou posterior, direto ou indireto, ao indivíduo ou à coletividade, decorrente da pesquisa".

No Artigo 5 da DUBDH que versa a respeito da Autonomia e da Responsabilidade Individual, é determinado que a autonomia dos indivíduos deve ser respeitada nas tomadas de decisões quando os mesmos tenham condições para responderem por si, e, quando não são capazes, ou possuem autonomia reduzida, necessitam de medidas especiais para proteger seu interesses e direitos individuais ${ }^{47}$. Hoje, "a esfera da vida prática esvaziou-se na medida em que a liberdade, nas sociedades capitalistas modernas, passou a ser considerada simples possibilidade de decidir individualmente sobre assuntos privados"(p. 32) ${ }^{142}$.

O artigo 6 da DUBDH ${ }^{47}$ versa sobre o consentimento, estabelecendo que só poderá haver intervenção médica preventiva, terapêutica e diagnóstica em um paciente com o seu consentimento prévio, após o mesmo ser esclarecido com informações adequadas e acessíveis ao seu nível de compreensão.

\footnotetext{
${ }^{x i}$ http://bvsms.saude.gov.br/bvs/saudelegis/cns/2013/res0466_12_12_2012.html
} 
consentimento apesar de manifesto também poderá ser retirado a qualquer momento desde que o paciente não queira mais participar, ou mesmo se sinta desconfortável por qualquer razão, sem que isso possa causar-lhe qualquer preconceito ou desvantagem.

O princípio do consentimento informado está em risco sempre que alguém garante saber o que é a coisa certa para fazer, e insiste em que sua decisão deve prevalecer sobre a autodeterminação do paciente, ainda que essa pessoa seja o médico ou um membro da família (p. 21) $)^{\mathrm{ii}}$

A concordância em receber tratamento é obrigatória e deve ser expressa previamente, de forma livre, fundamentada em esclarecimentos compreensíveis e apropriado a todos os participantes envolvidos, isso, após ter recebido informações de todos os procedimentos para a retirada de seu consentimento, e que isto poderá ser feito quando o participante desejar, seja qual for as razões ou tempo, sem que a retirada do consentimento possa causar-Ihe qualquer preconceito ou desvantagem. Só poderá haver exceções a este princípio, nos casos em que a legislação do Estado é respeitada e se estiver de acordo com os padrões éticos "consistentes com as provisões da presente Declaração, particularmente com o Artigo 27 e com os direitos humanos" 47.

O Artigo 7 da DUBDH ${ }^{47}$ expõe elementos sobre os indivíduos que não possuem capacidade para consentir, sendo necessário proteção especial conforme legislação. Nas práticas médicas o consentimento deve ser obtido tendo como prioridade o interesse do indivíduo, desde o processo para o aceite como também para a retirada do mesmo. O funcionamento de um serviço de saúde e as atividades de profissionais de saúde devem estar amparadas na legislação e ser realizadas com o propósito de beneficiar diretamente à saúde dos indivíduos envolvidos.

O Respeito pela Integridade Individual e Vulnerabilidade Humana é tratado no Artigo 8 da DUBDH ${ }^{47}$. É afirmado que nas práticas médicas, na aplicação do avanço científico e de tecnologias associadas, deve-se levar em consideração a vulnerabilidade humana. Deve-se respeitar e proteger a integridade individual de grupos com vulnerabilidade especifica. Segundo a Resolução CNS 466/2012, compreende-se que a vulnerabilidade é uma condição do indivíduo ou de

\footnotetext{
${ }^{x i i}$ UNESCO. The principle of respect for human vulnerability and personal integrity: Report of the International Bioethics Committee of UNESCO (IBC); 2013. Disponível em: http://www.unesco.org/new/en/social-andhuman-sciences/themes/bioethics/international-bioethics-committee/reports-and-advices/
} 
coletividades que, por algumas "razões ou motivos, tenham a sua capacidade de autodeterminação reduzida ou impedida, ou de qualquer forma estejam impedidos de opor resistência, sobretudo no que se refere ao consentimento livre e esclarecido". A confidencialidade e a privacidade, elementos principais da presente dissertação, são tratadas no artigo 9 da $\mathrm{DUBDH}^{47}$, que garante que deve haver respeito à privacidade e à confidencialidade das informações dos indivíduos. As informações não devem ser reveladas e usadas em propósitos diferentes daqueles para as quais foram coletadas e consentidas, necessitando do máximo de esforço para sua proteção, devendo estar também, em conformidade com a legislação internacional sobre direitos humanos.

Garay $^{143}$ afirma que a confidencialidade e a privacidade são direitos de todos pacientes:

\begin{abstract}
O reconhecimento da dignidade das pessoas é o fundamento moral da ideia de direito: obriga a considerar a pessoa sempre como fim em si mesma e nunca como meio; estabelece a inviolabilidade da pessoa assegurando sua idoneidade tanto na fase externa (saúde, integridade, biopsicossocial) como interna (privacidade e confidencialidade), e impõe a necessidade de considerar as pessoas como sujeitos e não como objetos, como portadoras de dignidade e não de preço (p.250) (tradução livre).
\end{abstract}

Além do direito de os pacientes terem suas informações resguardadas, é fundamental contextualizar o momento vivenciado: um cenário de doença, sofrimento físico ou psíquico, internação hospitalar, ou seja, um estado de fragilidade e de vulneração, o que significa para o paciente um possível grau de confiança naqueles que porventura de alguma forma amenizam seu sofrimento. Schramm ${ }^{144}$ lança mão do conceito vulnerabilidade, também presente na DUBDH, para explicitar a condição humana de poder ser acometido por doença, ter sofrimento e ser "ferido". O autor acrescenta que

\begin{abstract}
por estar exposto aos riscos da vida, em sua existência, o indivíduo pode passar da potencialidade - representada pela "vulnerabilidade" - ao ato - e tornar-se "vulnerado. Isso poderá ocorrer quando estiver submetido à atualização dos riscos, como no caso da instalação de um dano e, para quem se ocupa de saúde, das várias formas assumidas pelo fenômeno chamado "doença"(p.73).
\end{abstract}

Sánchez \& Bertolozzi ${ }^{145}$ discutem que determinados autores apresentam o modelo de vulnerabilidade "conformado por três planos interdependentes de determinação e, consequentemente, de apreensão da maior ou da menor vulnerabilidade do indivíduo e da coletividade"(p.321). Neste pensamento há três 
níveis de vulnerabilidade: individual, social e programática que, nesse caso, referese à chance de exposição das pessoas ao adoecimento, mas que colocam o indivíduo "na perspectiva da dupla-face, ou seja, o indivíduo e sua relação com o coletivo". Mas os autores lembram que os espaços coletivos e a determinação social, mais que os aspectos puramente individuais, colaboram para a constituição da saúde. “(...) a vulnerabilidade deve levar em conta a dimensão relativa ao indivíduo e o local social por ele ocupado"(p.321). Afirmam também que, "para intervir em situações de vulnerabilidade é imperativo o desenvolvimento de ações que envolvam "resposta social". É nesse sentido que a Bioética pode fornecer respostas.

A exposição da imagem de um paciente nos espaços coletivos, além de violar sua privacidade, pode se tornar um agente agonista que agrava seu estado de saúde ou, depois da convalescença e recuperação, pode causar uma rememoração não desejada do processo de adoecimento que, apesar de vivido no espaço público do hospital, agora é simulado nas redes sociais, onde não existe corporeidade e onde podem haver construções sociais, boas ou perversas, a respeito da imagem divulgada sem consentimento. 


\section{OBJETIVOS}

\subsection{OBJETIVO GERAL}

Conhecer a percepção ética de estudantes da área de saúde sobre o uso das imagens e/ou vídeos bem como informações de pacientes e sua exposição em meios sociais e discutir à luz da Declaração Universal sobre Bioética e Direitos Humanos.

\subsection{OBJETIVOS ESPECÍFICOS}

- Compreender as escolhas morais que estudantes do campo da saúde fazem em relação ao direito à privacidade do paciente;

- Verificar qual é o comportamento manifesto pelos estudantes de da área de saúde acerca da utilização de imagens/vídeos de pacientes;

- Avaliar qual é o significado de sigilo, autonomia, privacidade e de confidencialidade, das informações e imagem dos pacientes para os estudantes;

- Discutir, à luz da Declaração Universal sobre Bioética e Direitos Humanos, elementos para formação ética dos estudantes de saúde no que tange ao respeito pela privacidade e confidencialidade de informações. 


\section{MÉTODO}

\subsection{CARACTERÍSTICAS E UNIVERSO DE ESTUDO}

Com o propósito de responder os objetivos da pesquisa, o estudo foi de natureza descritiva e exploratória com abordagem mista. Segundo Figueiredo e Souza ${ }^{146}$ a pesquisa exploratória consiste em utilizar as técnicas de pesquisa qualitativa, quantitativa com observação da história ou relato de vida analisando o conteúdo por meio de entrevista diretiva, estudo de caso, pesquisa-ação, pesquisa-interação e outros. Após a coleta de dados foi realizada uma correlação das respostas com o referencial teórico escolhido.

No segundo semestre de 2015, a população total de estudantes dos cursos da área de saúde (Medicina, Odontologia, Enfermagem e Farmácia) da Universidade de Brasília era de 1.209 (hum mil duzentos e nove). Esses cursos foram escolhidos por serem dos que tradicionalmente os estudantes possuem maior contato com os pacientes. O tamanho da amostra foi calculado levando-se em consideração o universo do estudo, com uma margem de erro de 10\%, e com um nível de confiança de $95 \%$, considerando uma diversidade da população de $50 \%$. Com base nisso, o $n$ definido para pesquisa foi de 90 pessoas. O questionário foi aplicado via link online, enviado para a lista de e-mail dos estudantes, para os que se interessassem participar, responder. Dentre estes, 94 estudantes responderam. Assim, superando a expectativa do cálculo amostral. O referido questionário encontra-se nos anexos.

Responderam ao questionário estudantes de ambos os sexos, a partir dos 18 anos de idade. Como critérios de exclusão definiu-se que não responderiam estudantes legalmente incapazes e que não eram da área de saúde.

\subsection{DO PROCEDIMENTO METODOLÓGICO}

A coleta de dados foi realizada por meio de questionário estruturado, composto por questões fechadas e abertas, com o propósito de obter informações sobre a privacidade, sigilo e a confidencialidade por parte dos estudantes/estagiários dos cursos de medicina, enfermagem e odontologia, acerca da percepção que tem da confidencialidade e privacidade dos pacientes. O questionário foi criado no aplicativo Google Formulários, composto por 38 questões fechadas e abertas, e aplicado via link, enviado para a lista de e-mail disponibilizados pelas coordenações de curso da Faculdade de Ciências da Saúde. No corpo do e-mail seguiu, além do link de acesso 
ao questionário, o convite para os participantes da pesquisa bem como os esclarecimentos sobre todas as nuances do estudo. A primeira questão do questionário foi de concordância em participar ou não da pesquisa, equivalente a assinatura do TCLE.

Por se tratar de pesquisa que envolve contato direto com seres humanos, observou-se a legislação vigente do país, assim o projeto de pesquisa foi submetido à análise do Comitê de Ética da Faculdade de Ciências da Saúde de Universidade de Brasília. Todo o trâmite seguiu conforme a Resolução CNS no 466/2012 e demais normas regulamentadoras.

Os dados foram agrupados em planilhas e tratados com a ajuda do software estatístico SPSS v.21. Os resultados da análise descritiva foram ajustados em tabelas e avaliados em conformidade com os pressupostos teóricos definidos para o estudo.

Em seguida, o teor das respostas às questões abertas foi avaliado numa perspectiva hermenêutica, sendo o nível de compreensão dos estudantes, bem como se identificou fragmentos de discursos que reiteraram os argumentos acerca de competências e formação moral dos estudantes do campo da saúde encontrados na literatura. 


\section{RESULTADOS E DISCUSSÃO}

Os dados apresentados foram coletados por meio de questionário estruturado conforme descrito no método. Forma obtidas respostas de 94 estudantes. A primeira parte do questionário foi composta por questões para caracterização da amostra. $\mathrm{Na}$ segunda parte, por questões que permitiram fazer um levantamento da percepção ética dos estudantes de (medicina, enfermagem, odontologia e farmácia) sobre o processo de atendimento em saúde e o trato com a imagem, dados e informações do paciente frente à exacerbada divulgação em redes sociais.

Como a pesquisa foi projetada para ser respondida via questionário online, a primeira questão inquiriu se ao responder o questionário o participante autorizava a utilização das respostas no projeto de pesquisa e nas publicações dele decorrentes, e os 94 respondentes, $100 \%$ disseram sim.

As respostas das perguntas fechadas são expostas em tabelas e as respostas das questões "abertas" (discursivas) serão apresentadas segundo a importância que representam para o tema em estudo. As Tabelas 1,2 e 3 apresentam a caracterização da população estudada. A caracterização é um fator importante na análise do estudo tendo em vista que, algumas características podem ter influência no comportamento da população estudada.

Os dados apresentados na Tabela 1 evidenciam que a maioria dos que responderam eram do sexo feminino, não possuíam filhos, eram solteiros(as), da cor branca.

As informações da Tabela 2 apontam que mais da metade dos respondentes residem em Brasília, cerca da metade possui renda familiar entre 04 a 10 salários mínimos; mais da metade dos entrevistados afirmaram ter cursado o ensino fundamental e médio em instituição particular. Pelo exposto, o extrato amostral denota que uma grande parte dos participantes da pesquisa é da classe média. Este perfil é semelhante ao encontrado por outros pesquisadores ${ }^{147,148}$. Isso significa que essa característica provavelmente possibilitou maior oportunidade de acesso a computadores bem como ao uso da internet ao longo da vida, essa condição exerce forte influência na formação de uma pessoa e no modo de interagir com o mundo.

Tabela 1 Dados de caracterização da amostra, referentes ao sexo, filhos, estado civil, cor ou raça. 


\begin{tabular}{|c|c|c|c|c|c|c|c|c|c|c|c|}
\hline \multicolumn{3}{|c|}{ Sexo } & \multicolumn{3}{|c|}{ Tem Filhos } & \multicolumn{3}{|l|}{ Estado civil } & \multicolumn{3}{|c|}{ Cor ou Raça } \\
\hline & $\mathrm{N}$ & $\%$ & & $\mathrm{~N}$ & $\%$ & & $N$ & $\%$ & & $\mathrm{~N}$ & $\%$ \\
\hline M & 27 & $28,7 \%$ & Sim & 6 & $6.4 \%$ & Solteira(o) & 84 & $89,4 \%$ & Branca & 48 & $51 \%$ \\
\hline \multirow[t]{5}{*}{$\mathbf{F}$} & 67 & $71,30 \%$ & Não & 88 & $93.6 \%$ & Casada(o) & 8 & $8,5 \%$ & Preta & 6 & $6,4 \%$ \\
\hline & & & & & & $\begin{array}{l}\text { Separada(o) } \\
\text { ou } \\
\text { Divorciada(o) }\end{array}$ & 1 & $1,1 \%$ & parda & 30 & $31,9 \%$ \\
\hline & & & & & & Outros & 1 & $1,1 \%$ & Amarela & 2 & $2,2 \%$ \\
\hline & & & & & & & & & Indígena & 0 & 0 \\
\hline & & & & & & & & & $\begin{array}{l}\text { Sem } \\
\text { declaração }\end{array}$ & 8 & $8,5 \%$ \\
\hline To & 94 & $100 \%$ & & 94 & $100 \%$ & & 94 & $100 \%$ & & 94 & $100 \%$ \\
\hline
\end{tabular}

Fonte: Próprio autor.

Nas informações, Tabela 3, percebe-se que 97,9\% dos respondentes são estudantes ativos da Universidade de Brasília, situação desejada e esperada para o estudo; enquanto 2,1\% declararam não serem estudantes, por já ter concluído o curso. Quanto ao curso que estão estudando, 33\% disseram estar no curso de odontologia, $28,7 \%$ no curso de medicina, $23,4 \%$ no curso de enfermagem. Entretanto, $14,9 \%$ se enquadram em outros; que nessa pesquisa representou apenas estudantes do curso de Farmácia. Todos os semestres estiveram representados na amostra; destaca-se que 16,92\% dos respondentes declararam estar cursando o $8^{\circ}$, seguido de $13,16 \%$ cursando o primeiro semestre, $10.63 \%$ cursando o décimo semestre, $0.94 \%$ cursando o décimo primeiro semestre e $2.82 \%$ que já concluíram o curso. Adiante, na parte de definição de alguns conceitos, foram escolhidos os quatro semestres que mais representativos para uma comparação da percepção ética de início e de final de curso. 
Tabela -2 Dados de caracterização da amostra, referentes ao local de residência, renda familiar, instituição em que cursou o ensino fundamental e médio.

\begin{tabular}{|c|c|c|c|c|c|c|c|c|}
\hline \multicolumn{3}{|c|}{ Local de residência } & \multicolumn{3}{|l|}{ Renda Familiar } & \multicolumn{3}{|c|}{\begin{tabular}{|l} 
Instit. Cursou Ensino \\
Fundamental e Médio
\end{tabular}} \\
\hline & $\mathrm{N}$ & $\%$ & & $\mathrm{~N}$ & $\%$ & & $\mathrm{~N}$ & $\%$ \\
\hline Brasília & 51 & $54.3 \%$ & Até 01 salário mínimo & 2 & $2.1 \%$ & Pública & 31 & $33 \%$ \\
\hline $\begin{array}{l}\text { Cidade } \\
\text { satélite }\end{array}$ & 40 & $42.5 \%$ & $\begin{array}{l}01 \text { a } 03 \text { salários } \\
\text { mínimos }\end{array}$ & 6 & $6.4 \%$ & Particular & 56 & $59.6 \%$ \\
\hline $\begin{array}{l}\text { Cidade do } \\
\text { entorno }\end{array}$ & 2 & $2.2 \%$ & $\begin{array}{l}04 \text { a } 10 \text { salários } \\
\text { mínimos }\end{array}$ & 38 & $40.4 \%$ & Outras & 7 & $7.4 \%$ \\
\hline \multirow[t]{2}{*}{ Outros } & 1 & $1 \%$ & $\begin{array}{l}10 \text { a } 20 \text { salários } \\
\text { mínimos }\end{array}$ & 33 & $35.1 \%$ & & & \\
\hline & & & $\begin{array}{l}\text { acima de } 20 \text { salários } \\
\text { mínimos }\end{array}$ & 15 & $16 \%$ & & & \\
\hline Total & 94 & $100 \%$ & Total & 94 & $100 \%$ & & 94 & $100 \%$ \\
\hline
\end{tabular}

Fonte: Próprio autor.

Tabela - 3 Dados de caracterização da amostra, referentes a universidade que estuda, o curso de graduação, e em qual semestre está cursando.

\begin{tabular}{|c|c|c|c|c|c|c|c|c|}
\hline \multicolumn{3}{|c|}{$\begin{array}{l}\text { Você é estudante da } \\
\text { Universidade de } \\
\text { Brasília }\end{array}$} & \multicolumn{3}{|c|}{$\begin{array}{l}\text { Qual é seu curso de } \\
\text { graduação }\end{array}$} & \multicolumn{3}{|c|}{ Semestre Cursando } \\
\hline & $N$ & $\%$ & & $N$ & $\%$ & & $N$ & $\%$ \\
\hline Sim & 92 & $97.9 \%$ & Medicina & 27 & $28.7 \%$ & 19 & 14 & $13.16 \%$ \\
\hline \multirow[t]{12}{*}{ Não } & 2 & $2.1 \%$ & Enfermagem & 22 & $23.4 \%$ & $2^{\circ}$ & 11 & $10.34 \%$ \\
\hline & & & Odontologia & 31 & $33 \%$ & $3^{\circ}$ & 8 & $7.52 \%$ \\
\hline & & & Outros & 14 & $14.9 \%$ & $4^{\circ}$ & 9 & $9.57 \%$ \\
\hline & & & & & & $5^{\circ}$ & 6 & $5.64 \%$ \\
\hline & & & & & & $6^{\circ}$ & 7 & $7.44 \%$ \\
\hline & & & & & & $7^{\circ}$ & 3 & $2.82 \%$ \\
\hline & & & & & & $8^{\circ}$ & 18 & $16.92 \%$ \\
\hline & & & & & & 90 & 3 & $2.82 \%$ \\
\hline & & & & & & $10^{\circ}$ & 10 & $10.63 \%$ \\
\hline & & & & & & $11^{\circ}$ & 1 & $0.94 \%$ \\
\hline & & & & & & Concluído & 3 & $2.82 \%$ \\
\hline & & & & & & $\begin{array}{l}\text { Não } \\
\text { respondeu }\end{array}$ & 1 & $0.94 \%$ \\
\hline Total & 94 & $100 \%$ & & 94 & $100 \%$ & & 94 & $100 \%$ \\
\hline
\end{tabular}

Fonte: Próprio autor.

Ao responderem se já tiveram contato com paciente durante o curso (Tabela 4) os $76.60 \%$ dos estudantes, afirmaram que sim; quanto ao considerar quem é o protagonista na relação profissional paciente, $75,6 \%$ consideram que é o paciente, 0 que parece refletir o processo de humanização no ensino de saúde, que tem 
diminuído a postura paternalista, historicamente presente entre os profissionais do campo da saúde ${ }^{149,150}$.

Ao serem inquiridos se já tiraram foto ou fizeram filme de paciente, 55.3\% afirmaram não ter feito, porém $73,4 \%$ responderam que conhece alguém que já tirou foto ou fez filme de paciente.

Tabela 4 Dados que demostram a interação entre profissional de saúde com os pacientes, sobre: contato com paciente(s) durante o curso, quem é o protagonista na relação paciente e profissional de saúde, se já tirou foto ou fez algum filme de paciente, se conhece.

\begin{tabular}{|c|c|c|c|c|c|c|c|c|c|c|c|}
\hline \multicolumn{3}{|c|}{$\begin{array}{l}\text { Contato com } \\
\text { paciente(s) } \\
\text { durante o curso }\end{array}$} & \multicolumn{3}{|c|}{$\begin{array}{l}\text { o protagonista na relação } \\
\text { paciente e profissional } \\
\text { de saúde }\end{array}$} & \multicolumn{3}{|c|}{$\begin{array}{l}\text { Já tirou foto ou fez } \\
\text { algum filme de } \\
\text { paciente }\end{array}$} & \multicolumn{3}{|c|}{$\begin{array}{l}\text { Conhece alguém } \\
\text { que já tirou } \\
\text { foto/filme de } \\
\text { paciente }\end{array}$} \\
\hline & $\mathrm{N}$ & $\%$ & & $N$ & $\%$ & & $\mathrm{~N}$ & $\%$ & & $N$ & $\%$ \\
\hline Sim & $\begin{array}{l}7 \\
2\end{array}$ & $76.60 \%$ & O paciente & 68 & $75.6 \%$ & Sim & 42 & $44.7 \%$ & Sim & 69 & $\begin{array}{l}73.4 \\
\%\end{array}$ \\
\hline \multirow[t]{2}{*}{ Não } & $\begin{array}{l}2 \\
2\end{array}$ & $2.4 \%$ & $\begin{array}{l}\text { O } \\
\text { profissional } \\
\text { de saúde }\end{array}$ & 22 & $24.4 \%$ & Não & 52 & $55.3 \%$ & Não & 25 & $\begin{array}{l}26.6 \\
\%\end{array}$ \\
\hline & & & outros & & & & & & & & \\
\hline Total & $\begin{array}{l}9 \\
4\end{array}$ & $100 \%$ & & 94 & $100 \%$ & & 94 & $100 \%$ & & 94 & $100 \%$ \\
\hline
\end{tabular}

Foi solicitado aos estudantes que comentassem onde, quando e por que as fotos ou filmes foram feitos(as), assim, em uma avaliação geral, a maioria argumentou que as fotos ou filmes eram para fins de implementar trabalhos acadêmicos ou científicos, outros para registro do relato clínico; mostrar o resultado final do trabalho ao professor; fotografias do antes e depois para avaliação do resultado; alguns para estudo de caso. Entretanto, o relato de uma aluna chamou muita atenção, e as respostas foram divididas em duas partes: uma parte na Tabela 5 e a outra, em uma lista com as respostas literais de apenas uma estudante, para melhor análise.

Alguns bioeticistas têm se preocupado com a questão da ambiência na formação dos estudantes da saúde ${ }^{136,151-153}$. Não é incomum o relato de enfrentamento de dilemas morais entre estudantes, internos e residentes. Desta forma, é preciso investir na orientação acerca do uso de dados e informações de paciente ${ }^{154}$. Neste sentido, a formação para o respeito pela autonomia e privacidade do paciente, bem como o treinamento adequado para lidar com os sistemas 
eletrônicos de registro e a delimitação de normas de etiqueta (por exemplo, quando deixar de olhar ou quando parar de ouvir) e de princípios éticos precisa fazer parte da formação humanística dos futuros profissionais de saúde. Isto significa ter que capacitar professores e preceptores para que adequadamente orientem seus estudantes.

$\mathrm{Na}$ Tabela 5 são registradas as situações onde foram realizadas capturas de imagens de pacientes.

Tabela - 5 Dados de onde, quando e porque as fotos/filmes foram feitos.

\begin{tabular}{|c|c|c|c|}
\hline № & Onde & Quando & Por Que \\
\hline 1 & $\begin{array}{l}\text { Na clínica escola de } \\
\text { fisioterapia }\end{array}$ & & $\begin{array}{l}\text { registrar a evolução da reabilitação do paciente e para os } \\
\text { slides das aulas, congressos, encontros acadêmicos e artigos } \\
\text { científicos. }\end{array}$ \\
\hline 2 & Na clinica & & $\begin{array}{l}\text { mostrar o resultado final para o professor da prótese total } \\
\text { removível e para um relato clinico }\end{array}$ \\
\hline 3 & $\begin{array}{l}\text { No ambulatório de } \\
\text { estomaterapia do } \\
\text { HUB }\end{array}$ & & $\begin{array}{l}\text { fotografamos apenas os membros com ferida após os pacientes } \\
\text { assinarem o TCLE. As fotos são utilizadas para fins de } \\
\text { acompanhamento do tratamento e não são divulgadas nas } \\
\text { redes sociais. }\end{array}$ \\
\hline 4 & No HUB & & $\begin{array}{l}\text { Fotografias de antes/depois do tratamento, para avaliação do } \\
\text { resultado e recordação para estudo. }\end{array}$ \\
\hline 5 & & & $\begin{array}{l}\text { Já tirei foto de lesões dos pacientes para avaliação e } \\
\text { acompanhamento. }\end{array}$ \\
\hline 6 & $\begin{array}{l}\text { Fiz foto durante o } \\
\text { estágio no CAPs }\end{array}$ & & $\begin{array}{l}\text { não tinha nenhum objetivo relacionado à disciplina. Foi durante } \\
\text { a oficina da horta terapêutica apenas para guardar de } \\
\text { recordação. }\end{array}$ \\
\hline 7 & No pronto socorro & & para mostrar ao staff uma lesão em membros inferiores. \\
\hline 8 & $\begin{array}{l}\text { no ambulatório de } \\
\text { Dermatologia }\end{array}$ & & $\begin{array}{l}\text { Tirei fotos de } 3 \text { pacientes que atendi } \\
\text { para incluir em um trabalho acadêmico que consistia em relato } \\
\text { de caso. Não inclui o rosto dos pacientes nas fotos. Expliquei } \\
\text { de antemão o objetivo das fotos e solicitei autorização verbal } \\
\text { dos pacientes. }\end{array}$ \\
\hline 9 & $\begin{array}{l}\text { em atendimento } \\
\text { ambulatorial }\end{array}$ & & $\begin{array}{l}\text { Já aconteceu incontáveis vezes, } \\
\text { registrando feridas e lesões elementares de pele (a mando do } \\
\text { staff), em centro cirúrgico registrando a técnica de } \\
\text { procedimento e peças cirúrgicas. }\end{array}$ \\
\hline 10 & & & $\begin{array}{l}\text { Paciente de } 3 \text { meses apresentando crise convulsivas. Filmado } \\
\text { para mostrar ao neurologista. }\end{array}$ \\
\hline 11 & $\begin{array}{l}\text { na clinica } \\
\text { odontológica do } \\
\text { HUB }\end{array}$ & & $\begin{array}{l}\text { A partir do } 4^{\circ} \text { semestre, } \\
\text { frequentemente, para registrar casos clínicos junto aos } \\
\text { professores }\end{array}$ \\
\hline 12 & $\begin{array}{l}\text { Clínica de } \\
\text { Odontologia }\end{array}$ & & $\begin{array}{l}\text { por razões pessoais. As fotos foram feitas com a autorização } \\
\text { dos responsáveis. }\end{array}$ \\
\hline 13 & $\begin{array}{l}\text { Projeto de extensão } \\
\text { em trauma dental }\end{array}$ & & publicação de artigo científico. \\
\hline 14 & $\begin{array}{l}\text { Na clínica } \\
\text { odontológica }\end{array}$ & $\begin{array}{l}\text { ano } \\
2015\end{array}$ & $\begin{array}{l}\text { por motivo de relato de caso clínico, porém com consentimento } \\
\text { da paciente. }\end{array}$ \\
\hline
\end{tabular}

Fonte: Próprio autor. 


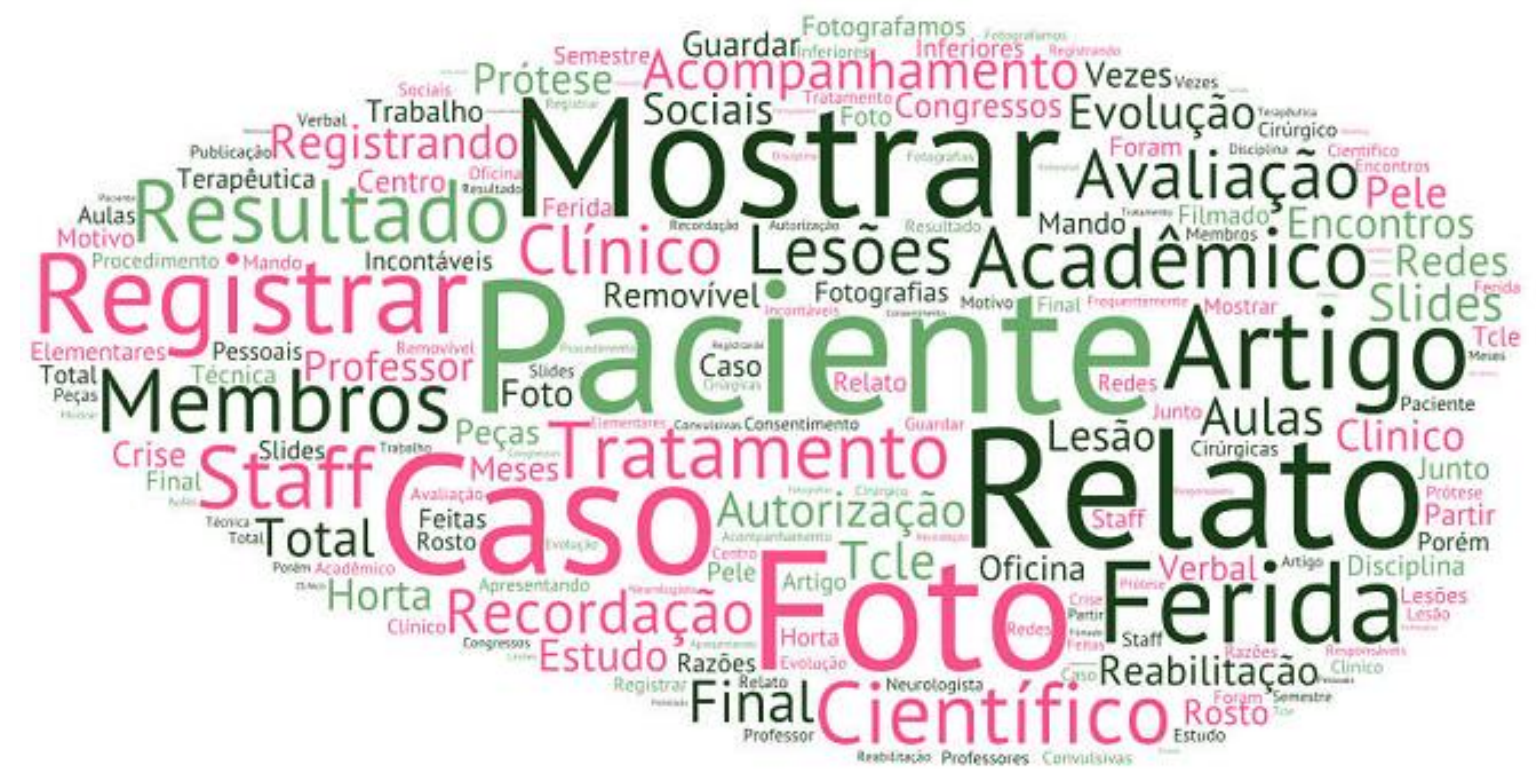

Figura - 1 Nuvem de palavras construída a partir das respostas da Tabela 5. Fonte: Próprio autor.

Uma breve análise das repostas (Figura 1) permite identificar que o registro de caso parece ser a justificativa mais frequente para registro de imagens de pacientes. O registro fotográfico médico tem sido feito desde $O$ início do século $X X^{155,156}$ e é frequentemente encontrado em livros e materiais didáticos. Harting ${ }^{157} \mathrm{e}$ colaboradores afirmam que:

Medical photographic image capture and data management has undergone a rapid and compelling change in complexity over the last 20 years. This is because of multiple factors, including significant advances in ease of photograph capture, alongside an evolution of mechanisms of data portability/dissemination, combined with governmental focus on health information privacy. Literature to guide medical, legal, governmental and business professionals when dealing with issues related to medical photography is virtually nonexistent.

E com base nesta lacuna, uma das motivações para a presente pesquisa, que é reforçada a necessidade de discutir o tema junto aos estudantes. As fotografias,

\footnotetext{
xiii Fotografia médica e a gestão da captura de imagens sofreu uma mudança rápida e convincente em termos de complexidade ao longo dos últimos 20 anos. Isto é por causa de vários fatores, incluindo avanços significativos na facilidade de captura de fotografia, ao lado de uma evolução dos mecanismos de portabilidade de dados / divulgação, combinados com foco governamental sobre a privacidade das informações de saúde. Literatura para orientar médicos, legais, governamentais e profissionais de negócios ao lidar com questões relacionadas com a fotografia médica é praticamente inexistente.
} 
em campos como a odontologia e a dermatologia, são ferramentas de trabalho do profissional de saúde ${ }^{158}$. Contudo, devem ser realizadas dentro da lógica de proteção ao prontuário do paciente, que lhe pertence e para o qual deve permitir ou não acesso, mediante consentimento livre e esclarecido. O registro de imagens pelo estudante pode não constituir parte da documentação clínica oficial do paciente. Se tomadas imagens, estas minimamente deverão vir acompanhadas de autorização do docente ou preceptor e da imprescindível permissão e do consentimento esclarecido do paciente.

Se o fato de tirar uma fotografia ou fazer uma filmagem já envolve elementos éticos complexos, quiçá a divulgação da imagem adquirida durante uma prática de aprendizado clínico. É uma violação deontológica e moral. Deontológica, porquê viola os códigos de ética profissional e, em alguns casos, as normas da unidade de saúde. Moral, porque transgride o limite da privacidade do paciente.

Ainda em resposta a questão anterior, uma estudante demonstra ter tirado fotografias de pacientes em vários momentos distintos; esclareceu que ela em si não divulgou as fotos em redes sociais, porém, alguém de seu convívio o fez. Pelo que discorre em sua resposta, em aproximadamente um mês a foto foi retirada do site; porém ela não disse ter solicitado a retirada da foto publicada. Comenta que houve repercussão positiva, pelas curtidas que a foto recebeu. Entretanto em resposta a outra questão, referente a permissão da divulgação de imagens suas como paciente, a mesma estudante respondeu que: "Não autorizaria fotos minhas durante atendimento, justamente por achar que não é ético e é constrangedor para a pessoa enquanto paciente". Com isso, mostra ter consciência da transgressão moral do ato de capturar a imagem de pacientes, como também da possibilidade de repercussão maléfica para o paciente. saúde:

Abaixo seguem os relatos de captura de imagens nas atividades de atenção à

- Clínica Odontológica do HUB - tirei as fotos para a confecção de painéis para apresentação de projeto de extensão em exposição de eventos acadêmicos (não me recordo muito bem, mas foi aproximadamente nos períodos 2013-2014). Os pacientes da Clínica Odontológica do HUB assinam na primeira consulta um Termo de Consentimento Livre e Esclarecido (TCLE) que, se concordarem, permitem a utilização de fotos para eventos científicos. As fotos não permitem identificar

0 rosto do paciente.

- Unidade de Terapia Intensiva - HUB - Fotos tiradas para confecção de painel para apresentação de relato de caso em exposição de evento acadêmico (2013) As fotos mantiveram o sigilo do paciente, e mostraram apenas o terço inferior da face. Foi autorizada pela equipe da UTI e um TCLE foi assinado pela responsável 
pelo

paciente.

- Estágio supervisionado SESC - uma amiga tirou uma fotografia minha para guardar de recordação durante 0 atendimento, mas não foi divulgado em nenhuma mídia social e eletrônica (sem autorização do paciente - este assinou apenas o TCLE, mas que autoriza apenas para casos de publicação científica). As fotos não permitem identificar o paciente pois não mostra a face do mesmo. Primeiro semestre 2015.

- HUB - 2013 - Foi tirada uma foto com a paciente, o professor, eu e a minha dupla, que atendia comigo, para guardar de recordação após um semestre de atendimento e comemoração por finalização do tratamento de confecção de dentaduras (próteses totais) para paciente. A paciente concordou em fazer as fotos. Não foi divulgado em mídias sociais.

- HUB - 2014 - Foi tirada uma foto com o paciente, eu e minha dupla para comemorar após a finalização de longo tratamento odontopediátrico. O paciente, ainda criança, concordou com as fotos, bem como a sua mãe e responsável. Uma foto foi divulgada no Facebook por uma amiga, que não me contou, com o objetivo de fazer uma surpresa, e depois de um mês aproximadamente foi retirado por ela. As fotos foram enviadas para a responsável do paciente. Entretanto, as fotos não revelam nada sobre qual o tipo de tratamento foi feito, nem mesmo os problemas do paciente. Foi apenas uma foto da criança com o dentista para guardar de recordação.

- $\quad$ SESC - 2015: Estudar os casos. Foi tirada uma foto de um dente de um paciente para mostrar a uma professora que não estava presente no dia a fim de discutirmos o melhor tratamento para o caso. Também foram feitas fotos de outra paciente para mostrar o caso a um professor ortodontista que também não estava presente no dia da consulta. Foi feito sob autorização das pacientes e uma que era menor, foi autorizada pelo responsável, que também assinou o TCLE. Depois foram apagadas.

Quando questionados se ao tirar foto ou fazer filme (Tabela 6) foi solicitada autorização do paciente, 43,7\% dos entrevistados afirmaram ter solicitado; que destas, $32,1 \%$ foi verbal; $51,2 \%$ outros e $14,7 \%$ confirmaram que a autorização foi escrita. Também asseguraram (41,5\%) que no momento havia supervisor presente, $33 \%$ disseram que não havia supervisão. Quando confirmada a presença do supervisor, $27,7 \%$ disseram que era um professor e $2,1 \%$ falaram que era um preceptor.

Ao se pronunciarem sobre a finalidade das fotos ou filmes (Tabela 7), 31,20\% responderam o item, não se aplica, por considerar que não tiraram foto ou fizeram filme de paciente, $26,9 \%$ manteve as fotos consigo, e apenas $6,5 \%$ declararam ter divulgado em redes sociais. Nos casos de ter divulgado, foram instados a indicar para qual rede social enviaram o material. 56,2\% marcaram o item (não se aplica) por considerar que não divulgaram. Quando perguntados se a foto ou filme foi enviada para algum grupo (aberto ou fechado) nas redes sociais, 86,2\% disseram que não o fizeram, contra apenas $13,8 \%$ que publicaram. 
A presença do professor em cerca de $1 / 4$ das situações em que foi obtida imagem do paciente aponta para a necessidade de se revisitar o papel ético do professor. Este, em tese, além de passar seus conhecimentos técnicos, teria o papel de ensinar uma prática virtuosa para os estudantes. Siqueira afirma que:

cultivamos modelo educacional cativo de parâmetros como eficácia, rentabilidade econômica, esmero na formação técnica e subestimamos a educação em valores éticos. Nosso míope pluralismo moral concebeu a educação inspirada na busca do êxito pessoal, embalada pela competitividade sem escrúpulos na qual sempre acaba prevalecendo a vitória do mais forte. Como resultado, as universidades contribuem cada vez mais para formar profissionais egocêntricos e menos cidadãos empenhados em promover a solidariedade(p.8) ${ }^{151}$

Os participantes que responderam o item 'outros', quanto ao tipo de autorização solicitada para poder fazer as fotos ou filme de paciente, em grande parte esclareceu que não haviam feito filme e nem foto. Responderam e justificaram apenas porque o item do questionário eletrônico era de resposta obrigatória. Como parte da formação dos estudantes que responderam ao questionário se dá em âmbito do Hospital Universitário (HUB), onde o paciente assina um termo de consentimento inicial que, em tese, o faria compreender que se trata de um hospital escola, parece haver uma prática naturalizada na instituição, de que uma vez assinado o termo na primeira consulta, não será mais necessário obter seu consentimento; como se o paciente perdesse sua autonomia e não tivesse mais direito à privacidade, ou como se tornasse obrigado a fazer o que o profissional de saúde lhe solicitar.

Dos estudantes, $13.8 \%$ que assinalaram ter enviado fotos ou filme para algum grupo aberto ou fechado (Tabela 7), expuseram os motivos da divulgação argumentando, em sua maior parte, que o compartilhamento foi para finalidade de estudo e um único caso, disse ter enviado para a família, conforme exposto na Tabela 8.

Ao avaliar a assimetria das respostas na Tabela 8, quanto para quem seria a relevância da ação da divulgação, aparece a supremacia de interesse dos profissionais em relação aos dos pacientes, conduta que provavelmente será levada para a vida profissional na sociedade. A justificativa da divulgação mostra que o olhar é todo voltado para a questão de usar o paciente como objeto/meio para fins 
exclusivo de estudo, nas falas não transparece preocupação com os pacientes, com sua vulnerabilidade como preconiza a DUBDH. Siqueira citando alguns autores afirma que:

Lind realizou estudo com 746 estudantes de medicina ao longo de seis anos de formação acadêmica, concluindo ter havido regressão na competência em estabelecer juízos morais, o que ficou expresso pelo desprezo que os alunos progressivamente passavam a dedicar aos pacientes enquanto sujeitos morais autônomos ${ }^{13}$. Rego constatou situação semelhante e reconheceu nesse comportamento uma "ignóbil coisificação" do paciente, sendo a pessoa transformada em mero objeto de interesse profissional e despida de qualquer valor humano. Exemplificando tal perspectiva, o autor relata que um de seus alunos, ao se referir a pacientes humildes, atendidos em prontosocorro municipal do Rio de Janeiro, os identificava pelo acrônimo "Pimba", composto pelas iniciais das palavras: preto, indigente, mendigo, bandido e alcoólatra.(p.10) ${ }^{151}$

Tabela 6 Dados referentes a ação do profissional de saúde em obter ou não fotos ou filme de pacientes no ato do atendimento: se pediu autorização; se a autorização foi escrita, verbal ou outras formas; se havia algum supervisor e se este era professor, preceptor servidor do hospital, outros.

\begin{tabular}{|c|c|c|c|c|c|c|c|c|c|c|c|}
\hline \multicolumn{3}{|c|}{$\begin{array}{l}\text { Ao tirar fotos ou } \\
\text { fazer filmes de } \\
\text { pacientes, você } \\
\text { pediu autorização }\end{array}$} & \multicolumn{3}{|c|}{ A autorização foi } & \multicolumn{3}{|c|}{$\begin{array}{l}\text { Havia algum supervisor } \\
\text { no momento }\end{array}$} & \multicolumn{3}{|c|}{$\begin{array}{l}\text { O supervisor presente no } \\
\text { momento da obtenção da } \\
\text { imagem era }\end{array}$} \\
\hline & $\mathrm{N}$ & $\%$ & & $\mathrm{~N}$ & $\%$ & & $N$ & $\%$ & & $N$ & $\%$ \\
\hline Sim & 43 & $\begin{array}{l}45.7 \\
\%\end{array}$ & Verbal & 27 & $32.1 \%$ & Sim & 39 & $\begin{array}{l}41.5 \\
\%\end{array}$ & Professor & 26 & $27.7 \%$ \\
\hline Não & 8 & $\begin{array}{l}8.5 \\
\%\end{array}$ & $\begin{array}{l}\text { Escrit } \\
\text { a }\end{array}$ & 14 & $16.7 \%$ & Não & 31 & $33 \%$ & Preceptor & 2 & $2.1 \%$ \\
\hline $\begin{array}{l}\text { Não } \\
\text { se } \\
\text { aplic } \\
\text { a }\end{array}$ & 26 & $\begin{array}{l}27.7 \\
\%\end{array}$ & $\begin{array}{l}\text { Outro } \\
s\end{array}$ & 43 & $51.2 \%$ & $\begin{array}{l}\text { Não } \\
\text { se } \\
\text { aplica }\end{array}$ & 24 & $\begin{array}{l}25.5 \\
\%\end{array}$ & $\begin{array}{l}\text { Servidor } \\
\text { do } \\
\text { hospital }\end{array}$ & 5 & $5.3 \%$ \\
\hline \multirow[t]{3}{*}{$\begin{array}{l}\text { Outr } \\
\text { os }\end{array}$} & 17 & $\begin{array}{l}18.1 \\
\%\end{array}$ & & & & & & & $\begin{array}{l}\text { Não se } \\
\text { aplica }\end{array}$ & 47 & $50 \%$ \\
\hline & & & & & & & & & Outros & 14 & $14.9 \%$ \\
\hline & 94 & $100 \%$ & & 94 & $100 \%$ & & 94 & $100 \%$ & & 94 & $100 \%$ \\
\hline
\end{tabular}

Fonte: Próprio autor. 
Tabela 7 Dados referentes a postura do profissional de saúde quanto a captura e finalidade de imagem e/ou vídeos de pacientes e a divulgação nas redes sociais

\begin{tabular}{|c|c|c|c|c|c|c|c|c|c|c|c|}
\hline \multicolumn{3}{|c|}{$\begin{array}{l}\text { A finalidade das } \\
\text { fotos ou filmes }\end{array}$} & \multicolumn{3}{|c|}{$\begin{array}{l}\text { O que você fez com } \\
\text { as fotos ou filmes } \\
\text { após o uso }\end{array}$} & \multicolumn{3}{|c|}{$\begin{array}{l}\text { Se você divulgou em } \\
\text { redes sociais, indique } \\
\text { qual foi }\end{array}$} & \multicolumn{3}{|c|}{$\begin{array}{l}\text { A foto ou filme foi } \\
\text { enviada para } \\
\text { algum grupo } \\
\text { (aberto ou } \\
\text { fechado) na rede } \\
\text { social }\end{array}$} \\
\hline & $\mathrm{N}$ & $\%$ & & $\mathrm{~N}$ & $\%$ & & $\mathrm{~N}$ & $\%$ & & $\mathrm{~N}$ & $\%$ \\
\hline $\begin{array}{l}\text { Estudar } \\
\text { o caso }\end{array}$ & 14 & $15,1 \%$ & Apagou & 13 & $14,1 \%$ & Facebook & 2 & $2.2 \%$ & Sim & 13 & $13.8 \%$ \\
\hline $\begin{array}{l}\text { Registro } \\
\text { do caso }\end{array}$ & 25 & $26,9 \%$ & Manteve & 25 & $27,2 \%$ & Twitter & 0 & $0 \%$ & Não & 81 & $86.2 \%$ \\
\hline $\begin{array}{l}\text { Divulgar } \\
\text { o caso }\end{array}$ & 6 & $6,5 \%$ & $\begin{array}{l}\text { Divulgou } \\
\text { em redes } \\
\text { sociais }\end{array}$ & 5 & $5,4 \%$ & Whatsapp & 5 & $5.6 \%$ & & & \\
\hline $\begin{array}{l}\text { Não se } \\
\text { aplica }\end{array}$ & 29 & $\begin{array}{l}31,20 \\
\%\end{array}$ & $\begin{array}{l}\text { Não se } \\
\text { aplica }\end{array}$ & 29 & $31,5 \%$ & Flicker & 0 & $0 \%$ & & & \\
\hline \multirow[t]{4}{*}{ Outros } & 19 & 20.45 & Outros & 20 & $21,7 \%$ & Pinterest & 0 & $0 \%$ & & & \\
\hline & & & & & & Instagram & 4 & $4.5 \%$ & & & \\
\hline & & & & & & $\begin{array}{l}\text { Não se } \\
\text { aplica }\end{array}$ & 50 & $56.2 \%$ & & & \\
\hline & & & & & & Outros & 28 & $31.5 \%$ & & & \\
\hline Total & 94 & $100 \%$ & & 94 & $100 \%$ & & 94 & $100 \%$ & & 94 & $100 \%$ \\
\hline
\end{tabular}


Tabela - 8 Dados que mostram os motivos da divulgação de fotos/filmes em grupos fechados ou abertos.

\begin{tabular}{|c|c|c|c|}
\hline \multicolumn{4}{|c|}{$\begin{array}{l}\text { Explicação dos estudantes sobre o motivo da divulgação de fotos ou filmes } \\
\text { em algum grupo fechado ou aberto }\end{array}$} \\
\hline $\begin{array}{l}\text { Ação } \\
\text { relevante para } \\
\text { o paciente }\end{array}$ & $\begin{array}{l}\text { Ação relevante para o } \\
\text { profissional de saúde }\end{array}$ & $\begin{array}{l}\text { Ação relevante } \\
\text { para paciente e } \\
\text { profissional de } \\
\text { saúde }\end{array}$ & Ação Diversa \\
\hline \multirow[t]{8}{*}{$\begin{array}{l}\text { Grupo do } \\
\text { projeto de } \\
\text { extensão, tirar } \\
\text { dúvidas sobre } \\
\text { a melhor } \\
\text { conduta a ser } \\
\text { realizada }\end{array}$} & $\begin{array}{l}\text { layout do trabalho em } \\
\text { grupo }\end{array}$ & $\begin{array}{l}\text { Grupo de } \\
\text { residentes } \\
\text { responsáveis pelo } \\
\text { tratamento do } \\
\text { paciente. }\end{array}$ & $\begin{array}{l}\text { Enviei para } \\
\text { professora! }\end{array}$ \\
\hline & $\begin{array}{l}\text { Grupo Fechado: } \\
\text { compartilhamento com o } \\
\text { grupo de estudo de caso }\end{array}$ & & $\begin{array}{l}\text { Divulgado para } \\
\text { a família }\end{array}$ \\
\hline & $\begin{array}{l}\text { Foi compartilhada no } \\
\text { grupo do estudo de caso } \\
\text { no Whatsapp, para } \\
\text { disponibilizar para a } \\
\text { pessoa que fosse juntar } \\
\text { as fotos e colocar no } \\
\text { trabalho. }\end{array}$ & & $\begin{array}{l}\text { Grupo do } \\
\text { whatsapp da } \\
\text { equipe, para } \\
\text { discussão e } \\
\text { registro do } \\
\text { caso. }\end{array}$ \\
\hline & $\begin{array}{l}\text { Compartilhar os registros } \\
\text { do Estudo de Caso com o } \\
\text { grupo que o realizou }\end{array}$ & & $\begin{array}{l}\text { A divulgação } \\
\text { não foi em } \\
\text { grupo. }\end{array}$ \\
\hline & $\begin{array}{l}\text { Divulgar para a turma } \\
\text { estudar o caso. }\end{array}$ & & Divulgar o caso \\
\hline & Caso clínico estudado & & \\
\hline & para prova. & & Tirar dúvida \\
\hline & $\begin{array}{l}\text { Para demonstrar antes / } \\
\text { depois, divulgação do } \\
\text { trabalho feito. }\end{array}$ & & \\
\hline
\end{tabular}


Ao responderem se a divulgação da foto/filme teve alguma repercussão, positiva ou negativa (Tabela 9), os estudantes consideraram que a repercussão foi positiva porque o compartilhamento em grande parte, segundo eles, foi com grupos de estudo, e que isso os ajudaram no aprendizado. Entretanto, é importante avaliar que as coisas, fatos, situações, realidades podem ter significado diferente para cada indivíduo. O que é positivo para um pode não ser para o outro, sendo influenciados por suas perspectivas individuais de vivencias, de construções ao logo da vida.

Nesse sentido Bauman ${ }^{50}$ quando fala dos tempos modernos, argumenta que os jovens, dessa nova geração, possuem valores que diferem dos de seus pais e dos de seus avós, que isso nunca vai se igualar por viverem a lógica das novas tecnologias. Dessa perspectiva de diferença de valores, tem-se abaixo (Tabela 9) as afirmações dos estudantes quanto a considerarem positiva ou negativa a publicização de imagens de pacientes em redes sociais. Pela ótica do que aqui importa ao estudante, a consideração é positiva, pois contribui para seus objetivos pessoais. Contudo em nenhum momento eles disseram ter sido positiva para o paciente, como, por exemplo, ter ajudado para a melhoria, física, psicológica ou social do paciente, o foco e todo voltado para o profissional, parece haver supremacia de interesse.

As respostas referentes as questões: "por quais motivos você enviou a foto/vídeo para algum grupo" e a questão "as fotos ou filmes tiveram alguma repercussão", possuem certa convergência pois os estudantes afirmam que a divulgação foi para estudo e que a repercussão foi positiva nesse sentido.

No entanto, apesar da maioria afirmar que não fez divulgação em redes sociais, é possível notar uma grade contradição do discurso e da prática, pois os próprios participantes, no item comentários sobre a pesquisa afirmaram:

- Achei um tema importante, pois o que mais vemos por aí, são fotos e vídeos expondo paciente;

- Achei um tema bastante relevante, porque é muito comum vermos fotos de pacientes serem divulgadas nas redes sociais e a maioria não menciona se 0 indivíduo autorizou ou não o uso de sua imagem. Durante a minha graduação, poucos professores/profissionais de saúde alertavam os alunos sobre a questão da divulgação das imagens dos pacientes. Espero que este assunto seja mais abordado nos cursos de graduação e também na pós-graduação 
Tabela 9 Dados sobre a repercussão da divulgação da foto/filme se foi positiva ou negativa.

\begin{tabular}{|c|c|c|}
\hline \multicolumn{3}{|c|}{$\begin{array}{l}\text { Comentário dos estudantes sobre - a divulgação da foto/filme teve alguma repercussão, } \\
\text { positiva ou negativa }\end{array}$} \\
\hline Repercussão positiva & Não teve repercussão & Repercussão Negativa \\
\hline \multicolumn{3}{|l|}{$\begin{array}{l}\text { Discussão para melhor } \\
\text { conduta }\end{array}$} \\
\hline $\begin{array}{l}\text { Repercussão positiva. } \\
\text { Assim, outros colegas } \\
\text { podem avaliar a qualidade } \\
\text { do seu trabalho. }\end{array}$ & Não teve repercussão & $\begin{array}{l}\text { Não houve nenhum } \\
\text { comentário de } \\
\text { repercussão negativa }\end{array}$ \\
\hline $\begin{array}{l}\text { Sim. O grupo que } \\
\text { confeccionou o Estudo de } \\
\text { Caso sentiu-se satisfeito com } \\
\text { a recuperação do paciente } \\
\text { evidenciada nos vídeos e } \\
\text { fotos. }\end{array}$ & $\begin{array}{l}\text { Acho que não repercutiu nem } \\
\text { positivamente e nem } \\
\text { negativamente, pois tenho } \\
\text { pouquíssimos seguidores e houve } \\
\text { poucas curtidas. Apenas curtidas e } \\
\text { nenhum comentário. }\end{array}$ & \\
\hline $\begin{array}{l}\text { positiva - pode- se fazer a } \\
\text { discussão do caso com } \\
\text { visualização do estado do } \\
\text { paciente. }\end{array}$ & Nenhuma repercussão & \\
\hline $\begin{array}{l}\text { Contribuiu para o aprendizado } \\
\text { dos alunos. }\end{array}$ & Não houve repercussão & \\
\hline
\end{tabular}

\section{Positiva, em estudo de caso em congresso. \\ Positiva, as pessoas curtiam e comentavam a foto; mas o post foi retirado pela pessoa que colocou.}

\section{Positiva para o trabalho}

Positiva pois ajudou na elucidação diagnóstica.

\section{Positiva, para discussão}

apenas.

Fonte: Próprio autor.

Esses comentários reforçam a percepção geral de contradição entre as respostas ao instrumento de avaliação (questionário), como exemplo aparece nas respostas: Não fiz foto, e logo em questão adiante, diz: a foto foi divulgada para estudo. Acrescenta-se que, quando compara-se com dados da literatura recente ${ }^{28 \text {, }}$ 29, 157, 159-164, é possível perceber que o discurso de que não se divulgam foto/vídeos de paciente em redes sociais é contraditório, pois apesar dos códigos de ética profissional reprovarem a divulgação de imagens e vídeos de pacientes, percebe-se que profissionais da área da saúde estão cada vez mais publicando suas rotinas de trabalhos nas redes sociais, para diversas finalidades. 
Essa publicização foi mostrada no artigo de Martorell e colaboradores ${ }^{36}$ que no desenvolver da pesquisa conseguiram selecionar imagens nos álbuns de Facebook de 17 diferentes profissionais da saúde. No total, foram acessadas 39 imagens, 27 publicadas por cirurgiões-dentistas e 12 por médicos. Isso confirma que o discurso que apareceu nesta pesquisa, de que as imagens e vídeos tirados no ambiente de atendimento de saúde não são divulgadas em redes sociais, é falacioso e contraditório, uma vez que os resultados encontrados demonstram que esta é uma prática corrente.

Outro acontecimento que evidencia a prática de divulgação é o fato que escandalizou a sociedade brasileira recentemente, que talvez a repercussão tenha sido maior por se tratar de uma pessoa pública, foi o "caso Cristiano Araújo"(cantor sertanejo que faleceu juntamente com sua namorada em um acidente de carro quando retornava de um show), foi publicado vídeo e imagens do corpo do cantor, quando ainda na clínica de saúde onde seu corpo se encontrava em processo de preparação para o sepultamento. A Polícia Civil indiciou os responsáveis no "crime de vilipendiar cadáver (desrespeito ao corpo):

O juiz William Fabian, da $3^{a}$ Vara de Família de Goiânia, concedeu uma decisão
liminar para que todas as imagens do corpo do cantor Cristiano Araújo, que
mostrem a preparação antes do enterro, sejam retiradas das páginas do Google e
Facebook. De acordo com o magistrado, assim que as empresas forem
notificadas, devem seguir a determinação imediatamente. Em caso de
descumprimento, a multa diária é de $\mathrm{R} \$ 10$ mil. "O que fizeram foi um desrespeito
muito grande, é extremamente revoltante. Por isso, se as companhias não
retirarem essas fotos e vídeos do ar, os responsáveis legais por cada uma
poderão até ser presos, pois a manutenção e divulgação configura o crime de
vilipendiar cadáver [desrespeito ao corpo]", afirmou o juiz (..) "Nos depoimentos,
tanto o Marco quanto a Márcia assumiram que sabiam do regimento interno da
clínica que impede o registro de imagens dos cadáveres. Ela afirmou que já
trabalhava no local há quatro anos e que o ato foi impensado. Por isso, a clínica
não deve ser responsabilizada. A não ser que os familiares entrem com ação na
Justiça", destacou o delegado

$\mathrm{O}$ acontecido demonstra como certos profissionais, diante da facilidade do uso das mídias sociais, mesmo conhecedores das normas, ainda sim cometem atos que ferem princípios como os defendidos na DUBDH e também a ética profissionalnormatizada nos Códigos Deontológicos. O ocorrido aponta que não é suficiente existir normas e regulamentos; é preciso uma consistente educação, tanto técnica

\footnotetext{
${ }^{\text {xiv }}$ Borges F. Juiz manda tirar do ar imagens do corpo do cantor Cristiano Araújo [homepage na internet ]. Goiás: G1; atualizada em 26 de junho de 2015; acesso em 14 de jan de 2016. Disponível em:

http://g1.globo.com/goias/musica/noticia/2015/06/juiz-manda-goo.
} 
como moral, de vivência humanizada, como evidenciada por exemplo, por correntes éticas de virtudes que expressam a necessidade de uma "ética médica da virtude", empregada na interação "médico-paciente", em que interagem grandezas da medicina, afetivas, de ordem espiritual, social, "voluntárias e religiosas". De tal modo, que os assuntos da moralidade em Medicina e no atendimento em saúde precisarão ser debatidos fundamentados nas virtudes e no caráter, uma vez que grande parte dos profissionais da saúde pode desviar-se com facilidade da estrutura de normas e dos Códigos de Ética que podem possuir lacunas ${ }^{165}$.

Ao responder à questão (Tabela 10), se autorizaria o compartilhamento de uma foto ou filme, se fosse o paciente, $52,1 \%$ dos respondentes disseram que sim, $3,2 \%$ marcaram a opção 'outros', em que alguns afirmaram que não gostariam de se expor, outros disseram que dependeria da finalidade da divulgação. Ao opinarem se há alguma diferença em tirar e postar uma foto/filme de uma pessoa/paciente e uma paisagem ou natureza morta, 92,5\% afirmaram sim, tem diferença; 3,2\% marcaram outros. Quanto à questão: você acha que enviar fotos/filmes de pacientes para redes sociais viola algum princípio ético $71,3 \%$ acreditam que sim, 21,3\% marcaram outros, por considerar que depende da situação, se houve autorização não fere, ou se ficar possível à identificação da pessoa pode haver violação.

Pouco mais da metade dos estudantes que participaram da pesquisa, afirmaram autorizar a divulgação de suas imagens/vídeos, o que caracteriza que os estudantes veem esse tipo de ação como algo natural, comum; mesmo respondendo que acreditam que há diferença em tirar foto ou fazer filme de uma pessoa e de uma paisagem, também considerarem em sua grande maioria, que divulgar foto ou filme de paciente em redes sociais, viola algum princípio ético. Essa situação pode ter relação com o que Bauman ${ }^{86}$ caracterizou como crise dos valores na modernidade líquida. 
Tabela - 10 Dados referentes a percepção e a empatia com o paciente.

\begin{tabular}{|c|c|c|c|c|c|c|c|c|}
\hline \multicolumn{3}{|c|}{$\begin{array}{l}\text { Autorizaria o } \\
\text { compartilhamento de } \\
\text { uma foto ou filme, se } \\
\text { você fosse o paciente }\end{array}$} & \multicolumn{3}{|c|}{$\begin{array}{l}\text { Você acha que existe alguma } \\
\text { diferença em tirar e postar uma } \\
\text { foto/filme de uma } \\
\text { pessoa/paciente e uma } \\
\text { paisagem ou natureza morta }\end{array}$} & \multicolumn{3}{|c|}{$\begin{array}{l}\text { Você acha que enviar } \\
\text { fotos/filmes de pacientes para } \\
\text { redes sociais viola algum } \\
\text { princípio ético }\end{array}$} \\
\hline & $\mathrm{N}$ & $\%$ & & $\mathrm{~N}$ & $\%$ & & $\mathrm{~N}$ & $\%$ \\
\hline Sim & 49 & $52.1 \%$ & Sim & 86 & $92.5 \%$ & Sim & 67 & $71.3 \%$ \\
\hline Não & 25 & $26.6 \%$ & Não & 4 & $4.3 \%$ & Não & 7 & $7.4 \%$ \\
\hline Outros & 20 & $21.3 \%$ & Outros & 3 & $3.2 \%$ & Outros & 20 & $21.3 \%$ \\
\hline Total & 94 & $100 \%$ & & 94 & $100 \%$ & & 94 & $100 \%$ \\
\hline
\end{tabular}

Quanto explicar os motivos pelos quais autorizaria ou não a divulgação de fotos/filmes seus enquanto paciente (Tabela 11), os estudantes, em número bastante expressivo, afirmaram que é importante para fins acadêmicos e científicos. Onde foi possível uma identificação de três pensamentos: o primeiro, representados pelos $52.1 \%$ que disseram autorizar; transparecendo em suas repostas que esse é um hábito/ato bem naturalizado. O segundo pensamento, dos que disseram que não autorizaria por considerar violação de sua privacidade e sigilo, e por sentir desconfortável diante de exposição em redes sociais. O terceiro, dos que responderam 0 item 'outros'- explicando que dependeria dos motivos e das condições permitiriam a captura de sua imagem, se não fossem expor sua identidade, se fosse Ihes solicitada autorização antecipada, ou para apenas grupos fechados de estudo, para fins exclusivamente acadêmicos e ou científicos, dados evidenciados na Tabela 11.

Ao afirmar que enviar fotos/filmes de pacientes para redes sociais viola algum princípio ético, os estudantes foram inquiridos a dizer qual/quais seria $(\mathrm{m}) \mathrm{o}(\mathrm{s})$ princípio(s) ético(s) violados nessa divulgação (Tabela12). Assim, para compreendermos melhor, dividimos a análise em duas partes, uma com a contagem geral das palavras e princípios mais significativos a esta pesquisa, que apareceu nas respostas; e a outra análise é feita por meio da escolha das respostas dos estudantes dos 4 semestres que mais participaram da pesquisa, sendo dois do início de curso e dois mais do final do curso, para uma comparação de percepção ética.

Deste modo, os princípios e palavras mais representativas para esta pesquisa, que mais apareceram nas respostas foram: privacidade (29x); Sigilo(11x); 
confidencialidade(7x); Ética e anonimato apareceram cada uma (5x); Autonomia, consentimento e direito a imagem apareceram cada uma (4x); e integridade(2x).

Em aspectos gerais, fica perceptível que os estudantes consideram que se houver divulgação e esta não tiver sido autorizada, violará princípios fundamentais da relação profissional de saúde e paciente; o que aponta que eles possuem consciência de que divulgar fotos/vídeos de pacientes em redes sociais é uma violação. Isso é condizente com as vedações impostas pelos códigos deontológicos, como mostra o Código de Ética Médica ao médico, que em seu Art. 110 garante que é vedado ao médico: "Praticar a Medicina, no exercício da docência, sem o consentimento do paciente ou de seu representante legal, sem zelar por sua dignidade e privacidade ou discriminando aqueles que negarem o consentimento solicitado"(p.71).

Porém, algo que chamou muita atenção foi um estudante responder que dispor de dados de paciente, não viola nenhum princípio ético. Em seguida, em respostas a outras questões, ele manteve a ideia de que é algo normal a divulgação de imagens ao dizer que permitiria a divulgação de suas imagens enquanto paciente, dizendo "pois pode servir para pesquisa de tratamento e diagnóstico de doença", e acrescentou que não conhece nenhuma norma ou lei que trata do assunto.

Adiante segue a lista de respostas colhidas dos quatro semestres mais representativos, para poder-se avaliar se há diferença de percepção ética no início do curso (Tabela 11): 
Tabela - 11 Argumentos pelos quais os estudantes justificam se autorizaria ou não a divulgação de fotos/filmes seus enquanto paciente.

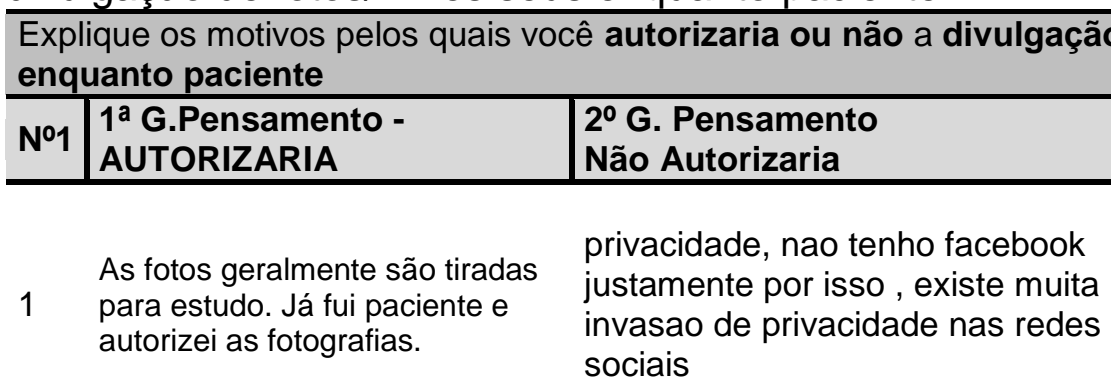

Vídeos/fotografias de procedimentos e

2 resultados/sintomas podem ser úteis no aprendizado de outros estudantes da área de saúde.

Não vejo problema se eu

3 confiasse na pessoa que tirou a foto.

Eu autorizaria para a finalidade de estudos, dependendo da minha condição clínica e da

4 exposição. Há casos muito pessoais que se compartilhado interfere na privacidade do paciente.

Não autorizaria devido ao meu direto de sigilo e privacidade. Sinto falta de privacidade ao autorizar que pessoas desconhecidas me conheçam por ambientes virtuais que não conheço.

Eu tenho direito de escolher quem deve ou nao saver que eu estou doente.

Porque discordo dessa postura médica de julgar a privacidade do paciente de acordo com a própria vontade, caso consultado pesaria os motivos antes vídeos ou fotos em redes sociais e

Não autorizaria fotos minhas

Autorizaria para estudo ou divulgação de alguma doença ou

5 sobre atendimento. Não autorizaria se me sentisse exposta e humilhada;

Aceitaria que minhas fotos/filmes

6 fossem divulgadas para estudo, para compor artigos/livros, para que um professor mostrasse em sala de aula.

Dependendo do tipo de foto, eu autorizaria. Por exemplo, para ser utilizada em um relato de caso. Também permitiria que uma foto minha junto ao profissional de saúde fosse divulgada em redes sociais por

8 um profissional cujo serviço eu admirei (mas apenas com autorização prévia e esclarecimento de em que tipo de mídia a foto seria exposta, e com a garantia de que detalhes sobre minha história clínica não seriam expostos, e que a foto
Acredito que não haja

necessidade para tal. Assim como me sentiria incomodada com a situação, como se tivesse minha privacidade invadida.

Os profissionais tem questões éticas e alguns não as cumpre portanto acho que não deve ser divulgado e quem deve ter conhecimento e acesso é apenas profissionais que estiverem assistindo o paciente e não deve ser espalhado, ninguém gosta de pessoas sabendo e falando da sua vida, portanto devemos lembrar disso e não fazer comentários desnecessários somente o que é inerente ao cuidado;

\section{G. pensamento} Outros (Depende)

Contanto que sirva de conhecimento dentro da faculdade, e apenas uma forma de conhecimento científico e comparação com outros casos.

Não autorizaria para compartilhamento aberto em redes sociais para evitar exposição.

Autorizaria o compartilhamento em grupos fechados para aqueles interessados.

Em rede social iria me expor, mas acho valido para pesquisa cientifica Não autorizaria se fosse para divulgação livre em mídias sociais, apenas se fosse como o nosso caso, que tirou fotos para mostrar a evolução da paciente que acompanhamos durante o semestre.

Só autorizaria se nas fotos eu não fosse identificada e se os motivos fossem relacionados a divulgação de conhecimento; 
não seria usada para

propaganda).

Fonte: Próprio autor.

Os participantes foram questionados se saberiam definir alguns conceitos fundamentais para a conduta dos trabalhadores da saúde, para que tenham uma adequada interação com os pacientes, como preconizado na DUBDH. Nas respostas a pergunta (Tabela 12) aparece a confusão por parte dos estudantes quanto a definição dos conceitos dos princípios de autonomia, privacidade, confidencialidade e sigilo, condição que se mostra mais acentuada nas respostas as questões seguintes. Francisconi \& Goldim chamam a atenção para este fato:

Algumas vezes observamos que os médicos têm mais facilidade em manter a confidencialidade de seus pacientes mais abonados, sendo mais "flexíveis" em deixar escapar informações de seus pacientes mais empobrecidos tanto social como intelectualmente. No entanto, é moralmente inaceitável que os médicos, em função de variáveis socioeconômicas, ajam de maneira diferente em relação a qualquer princípio. É este um valor que deve ser precocemente transmitido e exemplificado aos alunos dos cursos médicos através de uma atitude correta por parte dos professores quando do seu exercício docenteassistencial nos hospitais universitários. As populações vulneráveis devem ser protegidas por políticas extremamente claras sobre o uso das informações geradas ao longo de seu atendimento pelo sistema de saúde. ${ }^{96}$ 
Tabela 12 Resposta dos estudantes sobre qual/quais seria $(\mathrm{m}) \mathrm{o}(\mathrm{s})$ princípio(s) éticos violados na divulgação de fotos/vídeos em redes sociais.

\begin{tabular}{|c|c|c|c|c|}
\hline Questão & $\begin{array}{l}\text { Se sua resposta foi } \\
\text { sim, qual seria(m) } \\
\text { o(s) princípio(s) } \\
\text { ético(s) violados } \\
\text { pela divulgação? }\end{array}$ & $\begin{array}{l}\text { Se sua resposta foi } \\
\text { sim, qual seria(m) } \\
\text { o(s) princípio(s) } \\
\text { ético(s) violados } \\
\text { pela divulgação? }\end{array}$ & $\begin{array}{l}\text { Se sua resposta foi } \\
\text { sim, qual seria(m) } \\
\text { o(s) princípio(s) } \\
\text { ético(s) violados } \\
\text { pela divulgação? }\end{array}$ & $\begin{array}{l}\text { Se sua resposta foi } \\
\text { sim, qual seria(m) } \\
\text { o(s) princípio(s) } \\
\text { ético(s) violados } \\
\text { pela divulgação? }\end{array}$ \\
\hline Linha & $10^{\circ}$ semestre & $8^{\circ}$ semestre & $2^{\circ}$ semestre & $1^{\circ}$ semestre \\
\hline 1 & $\begin{array}{l}\text { Sigilo profissional, } \\
\text { autonomia e } \\
\text { privacidade do } \\
\text { paciente e } \\
\text { preservação da sua } \\
\text { intimidade e } \\
\text { integridade. }\end{array}$ & $\begin{array}{l}\text { Seria quebrada a } \\
\text { privacidade do } \\
\text { paciente e o elo de } \\
\text { confiança entre o } \\
\text { paciente e o } \\
\text { profissional. }\end{array}$ & $\begin{array}{l}\text { Da ética } \\
\text { profissional. }\end{array}$ & $\begin{array}{l}\text { o princípio do } \\
\text { anonimato, da } \\
\text { privacidade, respeito } \\
\text { pelas pessoas e } \\
\text { beneficência. }\end{array}$ \\
\hline 2 & $\begin{array}{l}\text { O paciente tem } \\
\text { direito ao sigilo da } \\
\text { informação. Fotos } \\
\text { ou vídeos sem } \\
\text { consentimento são } \\
\text { uma violação direta } \\
\text { desse direito. }\end{array}$ & $\begin{array}{l}\text { Expor o paciente } \\
\text { desnecessariamente } \\
\text { para leigos,sendo } \\
\text { que os mesmos } \\
\text { poderiam fazer uso } \\
\text { para finalidades de } \\
\text { má-fé. }\end{array}$ & $\begin{array}{l}\text { O mesmo violado no } \\
\text { caso de fotos e } \\
\text { filmes com } \\
\text { cadáveres: se } \\
\text { aproveitar da } \\
\text { fragilidade de } \\
\text { alguém para expô- } \\
\text { lo. }\end{array}$ & $\begin{array}{l}\text { Seria falta de ética } \\
\text { do profissional, que } \\
\text { não está } \\
\text { respeitando o } \\
\text { estado e a } \\
\text { intimidade do } \\
\text { paciente }\end{array}$ \\
\hline 3 & $\begin{array}{l}\text { Não-maleficência . } \\
\text { "Ser doente" é um } \\
\text { estigma, e pode } \\
\text { prejudicar a pessoa } \\
\text { a nível pessoal e } \\
\text { profissional, ao } \\
\text { divulgar a foto, você } \\
\text { expõe o indivíduo a } \\
\text { esses riscos. }\end{array}$ & $\begin{array}{l}\text { A privacidade e o } \\
\text { anonimato do } \\
\text { paciente. }\end{array}$ & $\begin{array}{l}\text { Estaria violando o } \\
\text { direito de não expor } \\
\text { o paciente }\end{array}$ & $\begin{array}{l}\text { Violaria a ética se } \\
\text { for sem } \\
\text { consentimento do } \\
\text { paciente e } \\
\text { autorização e } \\
\text { violaria a auto- } \\
\text { imagem. }\end{array}$ \\
\hline 4 & $\begin{array}{l}\text { Exposição } \\
\text { desnecessária do } \\
\text { paciente. }\end{array}$ & $\begin{array}{l}\text { contanto que tenha } \\
\text { sido conversado } \\
\text { com o paciente. }\end{array}$ & $\begin{array}{l}\text { Acho que viola caso } \\
\text { não tenha a } \\
\text { autorização do } \\
\text { paciente ou familiar. }\end{array}$ & $\begin{array}{l}\text { Falta de respeito ao } \\
\text { paciente e } \\
\text { exposição } \\
\text { sensacionalista. }\end{array}$ \\
\hline 5 & $\begin{array}{l}\text { Artigo } 12 \text { da } \\
\text { declaração universal } \\
\text { dos direitos } \\
\text { humanos( todo } \\
\text { homem tem direito à } \\
\text { sua privacidade e } \\
\text { que ela seja } \\
\text { defendida). }\end{array}$ & & $\begin{array}{l}\text { violaçao da } \\
\text { privacidade, em } \\
\text { ambos os casos, a } \\
\text { nao ser que este } \\
\text { paciente concorde } \\
\text { previamente }\end{array}$ & $\begin{array}{l}\text { Simplesmente a } \\
\text { ética de ter o bom } \\
\text { senso e respeitar o } \\
\text { próximo. }\end{array}$ \\
\hline 6 & $\begin{array}{l}\text { Privacidade da } \\
\text { relação médico- } \\
\text { paciente. }\end{array}$ & & $\begin{array}{l}\text { Violação da } \\
\text { privacidade e do } \\
\text { sigilo das } \\
\text { informações. }\end{array}$ & Direitos autorais. \\
\hline Não sei & 0 estudantes & 4/18 estudantes & 0/11 estudantes & 1/14 estudantes \\
\hline Não viola & 0 estudantes & 2/18 estudantes & 0/11 estudantes & 0/14 estudantes \\
\hline
\end{tabular}

Fonte: Próprio autor. 
Tabela - 13 Definição do conceito de autonomia do paciente, feita pelos estudantes do $10^{\circ}, 8^{\circ} 2^{\circ}$ e $1^{\circ}$ semestre.

\begin{tabular}{|c|c|c|c|c|}
\hline $\begin{array}{l}\text { Quest } \\
\text { ão }\end{array}$ & $\begin{array}{l}\text { Você conseguiria definir } \\
\text { o conceito de autonomia } \\
\text { do paciente? Como? }\end{array}$ & $\begin{array}{l}\text { Você conseguiria } \\
\text { definir o conceito } \\
\text { de autonomia do } \\
\text { paciente? } \\
\text { Como? }\end{array}$ & $\begin{array}{l}\text { Você conseguiria } \\
\text { definir o conceito } \\
\text { de autonomia do } \\
\text { paciente? Como? }\end{array}$ & $\begin{array}{l}\text { Você conseguiria } \\
\text { definir o conceito de } \\
\text { autonomia do } \\
\text { paciente? Como? }\end{array}$ \\
\hline Linha & $10^{\circ}$ semestre & $8^{\circ}$ semestre & $2^{\circ}$ semestre & $1^{\circ}$ semestre \\
\hline 1 & $\begin{array}{l}\text { Capacidade do paciente } \\
\text { de decidir sobre as } \\
\text { alternativas de } \\
\text { tratamento propostas e } \\
\text { sobre o que deseja ou } \\
\text { não. Deve ser } \\
\text { respeitado. }\end{array}$ & $\begin{array}{l}\text { Quando o } \\
\text { paciente } \\
\text { conhece seus } \\
\text { direitos e } \\
\text { deveres e se } \\
\text { empodera deles }\end{array}$ & $\begin{array}{l}\text { O paciente tem, a } \\
\text { todo momento, o } \\
\text { poder de decisão } \\
\text { acerca do } \\
\text { tratamento ao qual } \\
\text { quer submeter-se. }\end{array}$ & $\begin{array}{l}\text { A autonomia do } \\
\text { paciente é a } \\
\text { capacidade do } \\
\text { indivíduo tomar suas } \\
\text { decisões baseado em } \\
\text { conhecimento prévio } \\
\text { sobre o assunto. }\end{array}$ \\
\hline 2 & $\begin{array}{l}\text { liberdade, direito do } \\
\text { paciente participar } \\
\text { ativamente do seu } \\
\text { processo de cuidar, } \\
\text { tomando parte das } \\
\text { decisões como membro } \\
\text { principal. }\end{array}$ & $\begin{array}{l}\text { Direito que ele } \\
\text { tem de dizer o } \\
\text { que quer. }\end{array}$ & $\begin{array}{l}\text { Suas } \\
\text { vontades,escolhas } \\
\text { e consentimento }\end{array}$ & $\begin{array}{l}\text { Seria o direito dele de } \\
\text { escolha de ser } \\
\text { fotografado ou não }\end{array}$ \\
\hline 3 & $\begin{array}{l}\text { Capacidade de decidir } \\
\text { por si mesmo, sem ser } \\
\text { induzido pelo profissional } \\
\text { de saúde ou por seus } \\
\text { acompanhantes, }\end{array}$ & $\begin{array}{l}\text { O paciente é } \\
\text { capaz de } \\
\text { responder por si } \\
\text { mesmo, é } \\
\text { responsável por } \\
\text { si e é livre para } \\
\text { tomar as suas }\end{array}$ & $\begin{array}{l}\text { É o paciente ter } \\
\text { direito sobre suas } \\
\text { escolhas, sem } \\
\text { interferências de } \\
\text { outra pessoa. }\end{array}$ & $\begin{array}{l}\text { Acredito que seja o } \\
\text { direito do paciente em } \\
\text { decidir o que fazer } \\
\text { quanto à sua } \\
\text { condição. }\end{array}$ \\
\hline
\end{tabular}

decisões.

\begin{tabular}{|c|c|c|c|c|}
\hline 4 & $\begin{array}{l}\text { O paciente ter o poder de } \\
\text { fazer as suas próprias } \\
\text { escolhas mediante a } \\
\text { orientação do } \\
\text { profissional de saúde. }\end{array}$ & $\begin{array}{l}\text { Direito do } \\
\text { paciente de } \\
\text { exibir a sua } \\
\text { doença ou não. }\end{array}$ & $\begin{array}{l}\text { A autonomia seria } \\
\text { a vontade livre do } \\
\text { paciente, } \\
\text { concordando ou } \\
\text { não com o } \\
\text { tratamento. }\end{array}$ & $\begin{array}{l}\text { Ele ter suas próprias } \\
\text { decisões. }\end{array}$ \\
\hline 5 & $\begin{array}{l}\text { Não corretamente, essa } \\
\text { definição ficou menos } \\
\text { clara a medida que } \\
\text { avancei no curso. } \\
\text { Paciente é mal } \\
\text { informado, mal instruído } \\
\text { e não tem conhecimento } \\
\text { para julgar o que é } \\
\text { melhor para si. }\end{array}$ & $\begin{array}{l}\text { Paciente tem } \\
\text { total controle } \\
\text { sobre o recurso } \\
\text { autônomo.. }\end{array}$ & & $\begin{array}{l}\text { Não ter sua } \\
\text { identidade } \\
\text { identificada. }\end{array}$ \\
\hline $\begin{array}{l}\text { Não } \\
\text { sabe } \\
\text { definir }\end{array}$ & $1 / 10$ estudantes & $8 / 18$ estudantes & 3/11 estudantes & 8/14 estudantes \\
\hline
\end{tabular}

Fonte: Próprio autor. 
Tabela - 14 Definição do conceito de privacidade do paciente, feita pelos estudantes do $10^{\circ}, 8^{\circ} 2^{\circ}$ e $1^{\circ}$ semestre.

\begin{tabular}{|c|c|c|c|c|}
\hline Questão & $\begin{array}{l}\text { Você conseguiria definir o } \\
\text { conceito de privacidade } \\
\text { do paciente? Como?1 }\end{array}$ & $\begin{array}{l}\text { Você conseguiria } \\
\text { definir o conceito de } \\
\text { privacidade do } \\
\text { paciente? Como? } 9\end{array}$ & $\begin{array}{l}\text { Você conseguiria } \\
\text { definir o conceito } \\
\text { de privacidade do } \\
\text { paciente? Como? }\end{array}$ & $\begin{array}{l}\text { Você conseguiria } \\
\text { definir o conceito } \\
\text { de privacidade } \\
\text { do paciente? } \\
\text { Como?3 } \\
\end{array}$ \\
\hline Linha & $10^{\circ}$ semestre & $8^{\circ}$ semestre & $2^{\circ}$ semestre & $1^{\circ}$ semestre \\
\hline 1 & $\begin{array}{l}\text { Manter sigilo sobre as } \\
\text { informações do paciente. } \\
\text { Tudo o que o paciente } \\
\text { revela deve ser restrito ao } \\
\text { profissional e não } \\
\text { revelado a terceiros. Os } \\
\text { pacientes não devem ser } \\
\text { observados por outras } \\
\text { pessoas durante o } \\
\text { atendimento, muito } \\
\text { menos expostos. }\end{array}$ & $\begin{array}{l}\text { O paciente deve ter } \\
\text { suas informações } \\
\text { mantidas sob sigilo } \\
\text { profissional e a } \\
\text { divulgação dessas } \\
\text { informações deve } \\
\text { ser autorizada pelo } \\
\text { paciente. }\end{array}$ & $\begin{array}{l}\text { O paciente tem, a } \\
\text { todo momento, o } \\
\text { poder de decisão } \\
\text { acerca das } \\
\text { informações da } \\
\text { relação médico- } \\
\text { paciente que o } \\
\text { médico pode expor } \\
\text { a qualquer pessoa } \\
\text { fora da relação. }\end{array}$ & $\begin{array}{l}\text { A privacidade do } \\
\text { paciente é um } \\
\text { direito que ele } \\
\text { tem de } \\
\text { preservar-se da } \\
\text { exposição e } \\
\text { manipulação de } \\
\text { seu corpo pelos } \\
\text { profissionais. }\end{array}$ \\
\hline 2 & $\begin{array}{l}\text { nao expor o paciente } \\
\text { contra a sua vontade, } \\
\text { zelar pela sua integridade } \\
\text { física e moral. }\end{array}$ & $\begin{array}{l}\text { Direito de não se } \\
\text { expor. }\end{array}$ & $\begin{array}{l}\text { A guarda da } \\
\text { imagem do } \\
\text { paciente em sua } \\
\text { condição }\end{array}$ & $\begin{array}{l}\text { Seria respeitar } \\
\text { seu } \\
\text { espaço,principios } \\
\text { e escolhas }\end{array}$ \\
\hline 3 & $\begin{array}{l}\text { Direito do paciente de não } \\
\text { ser exposto ou } \\
\text { constrangido por sua } \\
\text { condição. }\end{array}$ & $\begin{array}{l}\text { Paciente tem o } \\
\text { direito de se manter } \\
\text { anônimo, se for o } \\
\text { que desejar. }\end{array}$ & $\begin{array}{l}\text { Sim. O paciente } \\
\text { tem o direito de } \\
\text { não querer sua } \\
\text { imagem exposta e } \\
\text { ter sua privacidade } \\
\text { preservada. }\end{array}$ & $\begin{array}{l}\text { Ter a liberdade } \\
\text { em decidir por si } \\
\text { mesmo o que } \\
\text { pode ou não ser } \\
\text { feito quanto à } \\
\text { sua imagem. }\end{array}$ \\
\hline 4 & $\begin{array}{l}\text { Privacidade é o respeito à } \\
\text { demanda do paciente de } \\
\text { manter informações } \\
\text { pertinentes ao mesmo }\end{array}$ & $\begin{array}{l}\text { Quando o paciente } \\
\text { tem o direito de não } \\
\text { se expor para outros } \\
\text { (leigos ou não). }\end{array}$ & $\begin{array}{l}\text { É ter a sua } \\
\text { privacidade, aquilo } \\
\text { que ele não quer } \\
\text { mostrar } \\
\text { respeitada. }\end{array}$ & $\begin{array}{l}\text { Ele não se expor } \\
\text { para ninguém } \\
\text { caso não queira. }\end{array}$ \\
\hline 5 & $\begin{array}{l}\text { Seu espaço privado,sua } \\
\text { intimidade. }\end{array}$ & $\begin{array}{l}\text { Privacidade é o } \\
\text { poder de decisão de } \\
\text { exposição ou não } \\
\text { de sua } \\
\text { particularidade. }\end{array}$ & $\begin{array}{l}\text { A privacidade é } \\
\text { própria do } \\
\text { paciente, em que } \\
\text { ele tem direito de } \\
\text { escolha. }\end{array}$ & $\begin{array}{l}\text { Sim,poder } \\
\text { confiar no } \\
\text { profissional sem } \\
\text { ter medo de ter } \\
\text { fatos ou fotos } \\
\text { compartilhadas } \\
\text { pelo profissional } \\
\text { após o } \\
\text { atendimento }\end{array}$ \\
\hline $\begin{array}{l}\text { Não } \\
\text { sabe }\end{array}$ & 2/10 Estudantes & 9/18 estudantes & $3 / 11$ estudantes & 3/14 estudantes \\
\hline
\end{tabular}

Fonte: Próprio autor. 
Tabela - 15 Definição do conceito de confidencialidade, feita pelos estudantes do $10^{\circ}, 8^{\circ} 2^{\circ}$ e e $1^{\circ}$ semestre.

\begin{tabular}{|c|c|c|c|c|}
\hline Questão & $\begin{array}{l}\text { Você conseguiria } \\
\text { definir o conceito de } \\
\text { confidencialidade? } \\
\text { Como? }\end{array}$ & $\begin{array}{l}\text { Você conseguiria } \\
\text { definir o conceito de } \\
\text { confidencialidade? } \\
\text { Como? }\end{array}$ & $\begin{array}{l}\text { Você conseguiria } \\
\text { definir o conceito de } \\
\text { confidencialidade? } \\
\text { Como? }\end{array}$ & $\begin{array}{l}\text { Você conseguiria } \\
\text { definir o conceito de } \\
\text { confidencialidade? } \\
\text { Como? } \\
\end{array}$ \\
\hline Linha & $10^{\circ}$ semestre & $8^{\circ}$ semestre & $2^{\circ}$ semestre & $1^{\circ}$ semestre \\
\hline 1 & $\begin{array}{l}\text { As informações } \\
\text { fornecidas pelo } \\
\text { paciente são } \\
\text { confidencias, e devem } \\
\text { ser utilizadas para } \\
\text { auxiliar no tratamento, } \\
\text { e não reveladas a } \\
\text { terceiros. }\end{array}$ & $\begin{array}{l}\text { O recurso ou objeto } \\
\text { confidencializado } \\
\text { deve requerer certo } \\
\text { grau de } \\
\text { sensibilidade de } \\
\text { divulgação }\end{array}$ & $\begin{array}{l}\text { Sim. Manter sigilo } \\
\text { profissional. }\end{array}$ & $\begin{array}{l}\text { Manter em sigilo, em } \\
\text { segredo. }\end{array}$ \\
\hline 2 & $\begin{array}{l}\text { Preservar e resguardar } \\
\text { as informações } \\
\text { fornecidas pelo } \\
\text { paciente, de forma a } \\
\text { estabelecer relação de } \\
\text { confiança. Com acesso } \\
\text { permitido apenas a } \\
\text { pessoas autorizadas. }\end{array}$ & $\begin{array}{l}\text { Manter sigilo dos } \\
\text { dados do paciente } \\
\text { não contando a } \\
\text { ninguém a não ser } \\
\text { os próprios } \\
\text { profissionais que } \\
\text { estejam envolvidos } \\
\text { no caso. }\end{array}$ & $\begin{array}{l}\text { Não } \\
\text { divulgar,mostrar ou } \\
\text { dizer algo }\end{array}$ & $\begin{array}{l}\text { Seria manter o sigilo } \\
\text { profissional, } \\
\text { respeitando } \\
\text { principalnente o } \\
\text { paciente }\end{array}$ \\
\hline 3 & $\begin{array}{l}\text { Garantia de que o que } \\
\text { acontece na consulta } \\
\text { fica na consulta. Sem } \\
\text { isso, o paciente não } \\
\text { poderia expor todos } \\
\text { seus problemas, por } \\
\text { medo de isso "vazar", o } \\
\text { que prejudica o } \\
\text { diagnóstico e a } \\
\text { conduta. }\end{array}$ & $\begin{array}{l}\text { A confidencialidade } \\
\text { se refere justamente } \\
\text { a relação de } \\
\text { confiança entre o } \\
\text { profissional e o } \\
\text { paciente, que deve } \\
\text { resguardar as } \\
\text { informações } \\
\text { relatadas a ele pelo } \\
\text { paciente. }\end{array}$ & $\begin{array}{l}\text { Os dados são } \\
\text { confidencias e o } \\
\text { prontuário deve ser } \\
\text { mantido pelo } \\
\text { estabelecimento } \\
\text { sem que haja } \\
\text { violação da } \\
\text { privacidade. }\end{array}$ & $\begin{array}{l}\text { É direito do paciente } \\
\text { não ter sua } \\
\text { privacidade violada por } \\
\text { outra pessoa. }\end{array}$ \\
\hline 4 & $\begin{array}{l}\text { Confidencialidade é o } \\
\text { ato de passar } \\
\text { informação a outrem } \\
\text { esperando-se sigilo. }\end{array}$ & $\begin{array}{l}\text { Quando tudo o que } \\
\text { for abordado entre o } \\
\text { paciente e o } \\
\text { profissional não } \\
\text { deve ser exposto ( a } \\
\text { não ser queira seja } \\
\text { decidido por escrito, } \\
\text { que o material } \\
\text { poderá ser utilizado } \\
\text { apenas para fins } \\
\text { científicos. }\end{array}$ & $\begin{array}{l}\text { Compromisso com o } \\
\text { paciente em não } \\
\text { divulgar } \\
\text { informações dadas } \\
\text { por ele. }\end{array}$ & $\begin{array}{l}\text { A confidencialidade é } \\
\text { um direito que o } \\
\text { paciente tem de } \\
\text { resguardo das } \\
\text { informações, ou seja, } \\
\text { não ter as informações } \\
\text { fornecidas ao } \\
\text { profissional de saúde } \\
\text { disponíveis ou } \\
\text { divulgadas ao público } \\
\text { sem sua autorização. }\end{array}$ \\
\hline 5 & $\begin{array}{l}\text { Ficar restrito ao } \\
\text { consultório as } \\
\text { informações do } \\
\text { paciente. }\end{array}$ & $\begin{array}{l}\text { Confidencial é o } \\
\text { poder de decisão de } \\
\text { não expor. }\end{array}$ & $\begin{array}{l}\text { Qualquer } \\
\text { informação da } \\
\text { relação médico- } \\
\text { paciente só pode } \\
\text { ser exposta pelo } \\
\text { médico com o } \\
\text { consentimento do } \\
\text { paciente. }\end{array}$ & $\begin{array}{l}\text { Confidencialidade é } \\
\text { alguém confiar um } \\
\text { documento/imagem } \\
\text { privada para você } \\
\text { através de um acordo } \\
\text { que será confidencial. }\end{array}$ \\
\hline $\begin{array}{l}\text { Não } \\
\text { sabe } \\
\text { definir }\end{array}$ & 1/10 Estudante & 7/18 Estudantes & 3/11 Estudantes & 4/14 Estudante \\
\hline
\end{tabular}


Tabela - 16 Definição do conceito de sigilo, feita pelos estudantes do $10^{\circ}, 8^{\circ} 2^{\circ}$ e $1^{\circ}$ semestre.

\begin{tabular}{l|l|c|c|}
\hline $\begin{array}{l}\text { Quest } \\
\text { ão }\end{array}$ & $\begin{array}{l}\text { Você conseguiria } \\
\text { definir o conceito de } \\
\text { sigilo na relação } \\
\text { profissional de saúde- } \\
\text { paciente? Como? }\end{array}$ & $\begin{array}{c}\text { Você conseguiria } \\
\text { definir o conceito de } \\
\text { sigilo na relação } \\
\text { profissional de saúde- } \\
\text { paciente? Como? }\end{array}$ & $\begin{array}{c}\text { Você conseguiria } \\
\text { definir o conceito de } \\
\text { sigilo na relação } \\
\text { profissional de saúde- } \\
\text { paciente? Como? } 2\end{array}$ \\
\hline Linha & $10^{\circ}$ semestre & $8^{\circ}$ semestre & $2^{\circ}$ semestre \\
\hline
\end{tabular}

\section{$1 \quad$ Não consigo diferencia de confidencialidade. \\ Não exposição do paciente pela conduta profissional}

Sim. A privacidade do paciente deve ser mantida no consultório.
Não expor casos,

o princípio ético a que a Manter segredo e 2 confidencialidade está associada.

Tudo o que o paciente revela ou as informações fornecidas ao profissional não devem ser transmitidas

3 a ninguém, bem como dados acerca da sua situação de saúde. Em uma linguagem mais simples, é tudo segredo.

\section{Sigilo é o respeito à}

$4 \quad$ privacidade do paciente de saúde-paciente.

Ficar restrito ao consultório toda e qualquer informação que seja solicitado sigilo

\section{Sigilo- não vazamento}

6 de informações referente a um profissional.
Não divulgar dados, imagens sem autorização.

\section{pessoas ou situações para quem não está envolvido}

O sigilo consiste em manter resguardadas as informações confiadas pelo paciente ao profissional, sendo que as informações só devem ser utilizadas com fins terapêuticos e com a autorização do paciente.

\section{Não discutir casos de pacientes fora do} ambiente de trabalho.
Julgo ser sinônimo da confidencialidade, no caso da relação médico-paciente. Qualquer informação da relação médicopaciente só pode ser exposta pelo médico com o consentimento do paciente.

É aquilo que fica somente entre 0 profissional e 0 paciente.

Você conseguiria definir o conceito de sigilo na relação profissional de saúde-paciente? Como?

10 semestre relação profissional de saúde-paciente é a não divulgação das informações obtidas durante 0 atendimento/pres tação do serviço.

Seria respeitar o paciente e sua intimidade

Acredito que a relação pacienteprofissional da saúde se mantenha entre os mesmos unicamente, com exceção apenas com ciência de ambos.

Não expor informação do paciente.

\section{Manter em} segredo/ guardados as informações

O sigilo é não divulgar trocadas durante dados do paciente a conversa.

o Sigilo deveria ser entre profissional de saúde e pacientes. Terceiros não precisam saber sobre a vida do paciente.

\begin{tabular}{l|l|l|l|l}
\multicolumn{2}{c}{ ser vazado. } & paciente. \\
\hline $\begin{array}{l}\text { Não } \\
\text { sabe } \\
\text { definir }\end{array}$ & $2 / 10$ Estudantes & 8 Estudantes & $2 / 11$ Estudantes & 3/14 Estudantes \\
\hline
\end{tabular}

O recurso sigilado deve ser mantido no ambiente profissional hospitalar, e não deve 8 Estudantes 
Tabela 17 Resposta dos estudantes se conhece alguma norma ou lei que oriente acerca da divulgação de imagens de pessoas.

\begin{tabular}{l|l|l|l|l}
\hline Questão & $\begin{array}{l}\text { Você conhece alguma norma } \\
\text { ou lei que oriente acerca da } \\
\text { divulgação de imagens de } \\
\text { pessoas? Quais? }\end{array}$ & $\begin{array}{l}\text { Você conhece } \\
\text { alguma norma ou lei } \\
\text { que oriente acerca da } \\
\text { divulgação de } \\
\text { imagens de } \\
\text { pessoas? Quais? }\end{array}$ & $\begin{array}{l}\text { Você conhece } \\
\text { alguma norma ou } \\
\text { lei que oriente } \\
\text { acerca da } \\
\text { divulgação de } \\
\text { imagens de } \\
\text { pessoas? Quais? }\end{array}$ & $\begin{array}{l}\text { Você conhece } \\
\text { alguma norma ou lei } \\
\text { que oriente acerca } \\
\text { da divulgação de } \\
\text { imagens de } \\
\text { pessoas? Quais? }\end{array}$ \\
\hline Linha & $10^{\circ}$ semestre & $8^{\circ}$ semestre & $2^{\circ}$ semestre & 10 semestre \\
\hline
\end{tabular}

De forma específica, desconheço qual é a norma ou lei. Sei que existe e que não é permitido a divulgação de imagem de pessoas. Somente pode ser divulgado casos científicos, autorizados pelo paciente/responsável, mantendo o sigilo e de forma que as imagens não

1 permitam reconhecer a identidade do paciente. Em nosso currículo (Odontologia UnB) há uma disciplina optativa "Responsabilidade Civil dos Profissionais da Saúde", em que o professor orientou muito sobre 0 assunto, mas como há quatro anos que a cursei, não me recordo das normas ou leis especificamente.

Ouvi que o CFM havia tentado regulamentar tais 2 divulgações, porém não me informei mais sobre o assunto.
Não, mas sei que existe. Só não tenho em mente agora.
Já ouvi falar vagamente de algumas leis, sem conhecer ou confirmar a lei. Todas elas giram em torno de um ponto em comum: É proibida a divulgação em mídias sociais de conteúdos digitais de qualquer pessoa sem o seu consentimento.
Conheço apenas a lei 10.406 de 2002.
Profissionais de Enfermagem
No prontuário do HuB temos um termo Sim, não sei qual mas existe 3 lei que proíbe a divulgação de imagens de pacientes. explicando ao

paciente como

usaremos as

imagens, caso

existam.

\section{Direito}

autorais, direito de imagem.

\begin{tabular}{l|l|l|l|l}
\hline $\begin{array}{l}\text { Não } \\
\text { sabe } \\
\text { definir }\end{array}$ & $6 / 10$ estudantes & $14 / 18$ & $10 / 11$ Estudantes & $11 / 14$ Estudantes \\
\hline
\end{tabular}

Fonte: Próprio autor.

Tem uma lei que resguarda o direito de qualquer cidadão de não ter sua privacidade invadida, tanto online, quanto pessoalmente.

Direitos autorais.
Não, mas sei que existe.

\section{4}

$14 / 18$ 
Os participantes do estudo tiveram a possibilidade de expressarem-se sobre o tema de pesquisa. Expuseram suas impressões e vivências tanto da realidade vivida dia a dia referente a divulgação de imagens de paciente como de aspecto referente ao instrumento de estudo. A opinião dos estudantes aponta para necessidade de ampliação do debate do tema em disciplinas de formação humanística, como é o caso das disciplinas de introdução à bioética. A maioria afirma que responder ao questionário constituiu um momento para reflexão, uma vez que o tema é de relevância e bem atual. Assim seguem alguns de seus relatos:

- É importante abordar esse assunto tendo em vista que se o paciente não se sente confortável com este tipo de exposição, deveriam respeitados.

- Achei um tema importante, pois o que mais vemos por aí, são fotos e vídeos expondo paciente.

- Acho a pesquisa de grande valor, visto que há uma tendência muito grande de publicação de imagens de pacientes nas mídias sociais.

- Acredito que deveria haver uma maior conscientização sobre o tema.

- Apesar de os professores sempre falarem sobre a importância do sigilo, do não divulgar fotos, a disciplina Bioética ainda é facultativa nos currículos, inclusive, a definição dos conceitos acima foi muito superficial, talvez por eu não ter estudado o tema de forma mais profunda. Inclusive, esta pesquisa foi uma forma de conscientização. Quando me perguntaram se eu gostaria que divulgassem uma fotografia minha, pude perceber o quanto isso é constrangedor para o paciente (literalmente, me imaginei e me coloquei no lugar do paciente, com meu médico ou algum profissional divulgando uma fotografia minha - em minha própria imaginação me senti ofendida e exposta). Além disso, quando perguntaram sobre os conceitos, ficou claro a seriedade do tema, a responsabilidade do profissional e os direitos que o paciente possui.

- Muito atual e interessante.

- Nunca tirei fotos, porém, o faria, se tivesse a devida autorização do paciente e a utilizando somente para estudo do caso clínico e para mostrar o antes e depois para o próprio paciente

- O tema é muito relevante para os profissionais da saúde tomarem consciência que a publicação da imagem dos pacientes gerar informações ilícitas, abusivas, violação de direitos autorais e atitudes lesivas a direitos personalíssimos de outrem.

- Sim, ela é muito importante para se saber o perfil do profissional da saúde.

- Muito útil e importante; infelizmente ainda existem casos de pacientes expostos em redes sociais e não gostaria nem que eu ou outra pessoa de minha família fosse vítima de tal fato.

- Acredito que programas incentivando a divulgação de casos clínico, para que as pessoas entendam a importância dos para os pesquisadores.

- é um tema super atual e triste que ele seja tão atual porque as pessoas, profissionais estão utilizando indevidamente imagens dos pacientes e postando em redes sociais expondo-os e isso tem repercussão psicológica e social, apesar de existirem códigos e leis que falam sobre isso.

- Muito relevante frente aos constantes abusos e desrespeitos que vemos nas redes sociais.

- Muito útil colocar lado a lado o que se faz enquanto profissional e o que gostaria enquanto paciente.

- Muito pertinente esta pesquisa. Causou em mim uma reflexão sobre este direito do paciente, que muitas das vezes, é violado neste mundo de reality show. Pensar que eu não gostaria de ser fotografada enquanto paciente me alertou para "não fazer com o outro aquilo que não gostaria que fizesse comigo".

- O tema é extremamente relevante e preocupante do ponto de vista ético, diante do risco e da realidade de exposição alheia no contexto atual das redes sociais.

- Um tema muito interessante e que faz parte do dia a dia dentro da saúde e que requer cuidados. 
- Achei um tema bastante relevante, porque é muito comum vermos fotos de pacientes serem divulgadas nas redes sociais e a maioria não menciona se o indivíduo autorizou ou não o uso de sua imagem. Durante a minha graduação, poucos professores/profissionais de saúde alertavam os alunos sobre a questão da divulgação das imagens dos pacientes. Espero que este assunto seja mais abordado nos cursos de graduação e também na pós-graduação.

- Excelente! Fez-me pensar a respeito do tema e como ele é pouco abordado com os alunos de graduação. Estou à disposição para responder qualquer questionário que ajude nas pesquisas. Obrigada!

- Muito importante, pois só cabe ao paciente decidir o que fazer com sua imagem.

- Interessante! Achei a pergunta sobre "quem é o protagonista" um pouco tendenciosa. Acredito que todos queiram responder que é o paciente - pois é o moralmente correto. Porém, na prática diária, acaba que o profissional de saúde se coloca no centro. É tão respondi baseado na minha experiência pessoal, não nas minhas crenças.

- Não estou muito inteirada do conteúdo mas acho fundamental para público médico e a relação cuidado e o sigilo e confidencialidade que se seguem

- Ainda existe muito desrespeito e crime relacionados com a exposição indevida do tratamento, diagnóstico e da imagem de parte ou de todo corpo do paciente, especialmente para divulgar doenças raras ou quando o paciente está vulnerável, casos de abandono social, com parasitas, isso vira deboche e desrespeito profissional.

Chamou a atenção o relato de um estudante que também foi paciente e evidenciou os conflitos relativos a privacidade no atendimento, caracterizados no presente estudo:

- O paciente tem o direito a não o se expor, por exemplo, me lembro, uma vez no $\mathrm{H}$ univ de Brasília, eu me queixei $p$ um médico gastro de um problema, e ele sem pedir minha autorização no meio da consulta, chamou três residentes mulheres e me expos a elas como um paciente com um problema psíquico, ( me chamou de louco na frente delas), que eu não quero falar, eu me senti muito mal ali, achei aquilo ridículo e sem educação a parte desse medico , era explicito a intenção desse medico de apenas se amostrar para essas moças recém formadas, me usando como cobaia, eu nunca esqueci isso, não me lembro o nome desse medico, só sei que era gastroenterologista e cirurgião . mas enfim, é difícil se falar em ética num pais onde os valores morais estão em baixa. em todas as instituições , infelizmente.

Em 2011, um estudo ${ }^{117}$ realizado com sete entrevistados da áreas de saúde para averiguar práticas e conceitos usados pelos profissionais no ambiente de saúde mostrou que quanto ao conceito de privacidade houve um consenso de que esta é um direito dos pacientes em ter resguardadas as informações sobre suas vidas, independentemente de quem seja o paciente. Porém, houve divergência entre os profissionais, em estabelecer quais são as informações consideradas sigilosas, segundo eles, cada paciente determina o que é privado de acordo com a visão que tem do mundo. Dessa forma, evidenciando que ao se referir a privacidade há determinantes como juízo de valor dos profissionais, que podem ser divergentes daquele do paciente, o que pode contribuir para a quebra da confidencialidade. 


\subsection{AVALIAÇÃO GERAL DOS DADOS POR SEMESTRE}

Os dados também foram organizados em função dos semestre em que os estudantes estavam, a fim de verificar se existiam diferenças em relação a postura, uma vez que Siqueira ${ }^{151}$ faz um alerta quanto ao papel "desumanizador" que a formação técnica nos cursos exerce sobre os estudantes.

\subsection{1. $1^{\circ}$ Semestre}

Dos 14 estudantes, três tiveram contato com paciente, dois já tiraram fotos, e um chamou a atenção positivamente, por ter tirado foto e explicado: "Tirei foto dos pacientes que atendi no ambulatório de estomaterapia do HUB. No ambulatório, fotografamos apenas os membros com ferida após os pacientes assinarem o TCLE. As fotos são utilizadas para fins de acompanhamento do tratamento e não são divulgadas nas redes sociais", e para a obtenção da imagem foi solicitada autorização por escrito na presença de um servidor do hospital; o relato do estudante mostra que já no primeiro semestre teve bastante consciência das questões éticas envolvida na atividade.

Um estudante disse que não ter tirado foto, porém conhece alguém que tirou e divulgou no Whatsapp. Este afirmou que não permitiria divulgação de foto ou filme suas enquanto paciente.

Apenas um estudante disse não ter diferença de tirar foto/ filme de uma pessoa e uma natureza morta, essa mesma pessoa, acha que divulgar a imagem/filme de paciente não viola princípio ético.

\subsection{2. $2^{\circ}$ Semestre}

Dos 11 estudantes, somente três tiveram contato com pacientes, desses, dois tiraramm foto e um obteve autorização por escrito, enquanto o outro foi verbal, este último disse que a finalidade da foto foi sentimental e a imagem não foi divulgada.

Em outro caso, um estudante disse não ter tirado foto e em uma questão seguinte, disse que a foto foi divulgada em um grupo para estudo. Caracterizando desse modo, que há certa contradição nas falas e provavelmente nas ações. 
Todos os 11 respondentes do $2^{\circ}$ semestre acham que há diferença de tirar foto/filme de um paciente e de uma paisagem, e acreditam que se divulgadas, há violação ética.

\subsection{3. $8^{\circ}$ Semestre}

Dos 18 estudantes do $8^{\circ}$ semestre que participaram da pesquisa, todos afirmaram que já tiveram contato com paciente e somente quatro pessoas garantem que ainda não tiraram foto de paciente. Do total, 11 disseram que a autorização para tirar as fotos foi apenas verbal, enquanto 13 respondentes disseram que havia supervisor presente, 12 disseram haver professores e um preceptor. Os outros cinco respondentes, que obtiveram a autorização por escrito, tinham em sua companhia um professor. Isso leva novamente ao questionamento de qual seria o papel do educador neste processo. Visto que a maioria dos estudantes age em frente aos seus professores/preceptores, em desacordo as regras deontológicas, as regras para pesquisa com seres humanos e regras internacionais como as preconizadas na DUBDH e a Declaração Universal de Direitos Humanos, desrespeitando a privacidade o sigilo e a autonomia. Como já descrito anteriormente, um estudante do 8 semestre considera que não há diferença em tirar foto de uma paisagem e de um paciente, essa mesma pessoa, acha que se for divulgada a foto ou filme, não violará nenhum princípio ético; também não soube definir o conceito de autonomia, confidencialidade, privacidade e sigilo, e afirmou ainda que não conhece nenhuma norma ou lei que oriente acerca da divulgação de imagens de pessoas.

Dos 18 estudantes, um não autorizaria a divulgação de sua imagem, e um outro, disse que dependerá da situação e do meio de divulgação. Já 5/18 estudantes do $8^{\circ}$ semestre acreditam que divulgar foto/filme de paciente, não viola princípios éticos. Entre os 18 estudantes, 14 afirmaram que não conhece nenhuma norma ou lei que oriente acerca da divulgação de imagens de pessoas.

\subsection{4. $10^{\circ}$ Semestre}

Dos dez estudantes do $10^{\circ}$ semestre, todos já tiveram contato com paciente, seis tiraram foto do paciente, nove conhecem alguém que já tirou foto; somente quatro pediram autorização, e outros dois afirmaram: "muito raramente" (verbal) e 
"quase sempre" (verbal); em quatro das vezes havia um supervisor presente (professor). Quanto a divulgação em rede social, dois compartilharam no Facebook e um no Whatsapp, os demais disseram que mantiveram as fotos.

Ao responderem se autorizariam a compartilhamento de uma foto ou filme, se fossem o paciente, 6/10 estudantes disseram que autorizariam mas de modo a não serem identificados. Todos consideram que há diferença em tirar foto/filme de uma paisagem e de um uma pessoa/paciente e caso a foto/filme seja divulgada acham que ocorrerá violação de princípios éticos, com exceção de apenas um que acredita que se houver autorização, não ocorre violação ética. Entre os dez estudantes, cinco afirmam que não conhece nenhuma norma ou lei que oriente a respeito da divulgação de imagens de pessoas.

\subsection{ANÁLISE GERAL DA PERCEPÇÃO POR CURSO}

\subsubsection{ODONTOLOGIA}

Os estudantes de odontologia, todos disseram que já tiveram contato com pacientes, e a maioria [23/31 estudantes] já tiraram foto ou fizeram filme de paciente, todos conhecem alguém que já tirou foto ou fez filme; a maioria [23 pessoas] disse que solicitou autorização, das quais 17 foi verbal e 7 por escrito, e que havia supervisor presente (18 professores). Quando inqueridos em qual rede social divulgaram a foto/filme; três estudantes divulgaram no Instagram, dois por e-mail, dois no Facebook e 1 no Instagram e Facebook ao mesmo tempo. A divulgação em grupo foi feita por três estudantes, segundo os mesmos: um para tirar dúvida, o segundo para layout de trabalho em grupo e o outro para mostrar o antes e o depois.

Dos 31 estudantes 22 afirmaram que autorizariam a divulgação de sua imagem enquanto paciente; quatro disseram que não autorizariam pelos seguintes motivos: "Em rede social iria me expor, mas acho valido para pesquisa cientifica". O segundo por causa da "privacidade imagem pessoal", o terceiro "privacidade" e o quanto por "Questão pessoal, porém só para fins educativos e com tarja nos olhos, eu autorizaria”. Uma grande parte acredita que tirar foto de paciente e de uma paisagem é diferente, com exceção de um estudante do $8^{\circ}$ semestre que afirmou que não saberia dizer. 
Outro fato que chamou muita atenção foi a afirmação de seis estudantes que consideram que divulgar imagem de paciente em redes sociais não viola princípios éticos, desses, cinco cursando o $8^{\circ}$ semestre e um cursando o $6^{\circ}$ semestre. Isso demonstra que há uma falha grave no sistema de ensino, que estudante em véspera de se formar não tem preparo ético para exercer a profissão.

Dos 31 estudantes 10 disseram não saber definir o conceito de autonomia, privacidade e sigilo; outros nove não souberam definir confidencialidade. Quanto ao conhecimento de norma ou lei que oriente acerca da divulgação de imagens de pessoas, 25 estudantes afirmaram não conhecer nenhuma. De todos, apenas um tem maior conhecimento, enquanto outros dois fizeram uma verdadeira confusão de norma ou lei com direito. Essa é uma situação grave que carece de uma intervenção nos currículos do curso para a inclusão de disciplinas de bioética para uma efetiva preparação desses estudantes. Alguns disseram as seguintes frases abaixo:

- Tenho conhecimento acerca da existência das mesmas, porém, não estou familiarizada com elas

- Não. Meu curso oferta a disciplina de Responsabilidade Civil, que farei posteriormente. Talvez esse assunto seja abordado nessa disciplina.

- De forma específica, desconheço qual é a norma ou lei. Sei que existe e que não é permitido a divulgação de imagem de pessoas. Somente pode ser divulgado casos científicos, autorizados pelo paciente/responsável, mantendo o sigilo e de forma que as imagens não permitam reconhecer a identidade do paciente. Em nosso currículo (Odontologia UnB) há uma disciplina optativa "Responsabilidade Civil dos Profissionais da Saúde", em que o professor orientou muito sobre o assunto, mas como há quatro anos que a cursei, não me recordo das normas ou leis especificamente.

- No prontuário do HuB temos um termo explicando ao paciente como usaremos as imagens, caso existam.

- Sim. Sigilo profissional e paciente

- Direito autorais, direito de imagem.

\subsubsection{MEDICINA (27 estudantes)}

Dos 27 estudantes de medicina apenas dois não tiveram contato com paciente, do total 18 afirmam nunca ter tirado foto de paciente, enquanto 10 disseram ter tirado, os quais cursando do sexto ao décimo primeiro semestre. Todas as autorizações realizadas para tirar foto ou vídeos foi verbal, com um total de 11 respostas e que havia um supervisor presente. Ao responder se conhece alguém que já tirou foto ou fez filme de paciente, 21 responderam que conhece. Algo que despertou muita atenção foi o relato de um estudante que já tirou foto e disse: "Já aconteceu incontáveis vezes, em atendimento ambulatorial registrando feridas e 
lesões elementares de pele (a mando do staff), em centro cirúrgico registrando a técnica de procedimento e peças cirúrgicas", afirma que raramente solicita autorização e quando solicitada e apenas verbal; diz também que no momento havia professor, preceptor e residentes presentes. A finalidade foi de registro do caso e ele garante que sempre usou o celular do preceptor e não sabe qual foi a destinação das mesmas, contudo, logo em seguida disse que foi enviada para o grupo do WhatsApp para registro e discussão do caso. Adiante ao ser questionado se autorizaria a divulgação de foto/vídeos seus enquanto paciente, afirmou que não autorizaria e justificou: "Porque discordo dessa postura médica de julgar a privacidade do paciente de acordo com a própria vontade, caso consultado pesaria os motivos antes". Também expressou que há diferença de tirar foto ou fazer vídeos de uma pessoa e uma paisagem, que a divulgação de imagens de pacientes viola algum princípio ético, por exemplo: "Artigo 12 da declaração universal dos direitos humanos (todo homem tem direito à sua privacidade e que ela seja defendida)".

Esse fato caracteriza que está faltando o exemplo virtuoso dos profissionaisprofessores na formação dos estudantes ${ }^{166-168}$. Esse caso reforça a perspectiva de Siqueira ${ }^{151,169,170}$ de que a desumanização na atenção e o paternalismo são vieses na formação dos novos profissionais de saúde. Alguns teóricos que se debruçam sobre a formação ética profissional afirmam que o exemplo prático faz toda diferença na formação do profissional, para o bem ou para o mal ${ }^{166,171-173}$. Ainda, o mesmo estudante afirma que não conseguiria definir corretamente o conceito de autonomia porque a definição foi ficando menos clara na medida que avançou no curso. Considera: "Paciente é mal informado, mal instruído e não tem conhecimento para julgar o que é melhor para si”, o que reforça a lógica viciada do paternalismo.

Dos 27 alunos, apenas dois informam ter divulgado as fotos em redes sociais, um divulgou na turma e o outro no Whatsapp. Quanto a divulgação em grupo fechado ou aberto, quatro afirma ter divulgado. Ao responder se autorizaria a divulgação de foto/filme enquanto paciente, 12 de 27 disse que autorizariam; enquanto 7/27 afirmaram que depende ou talvez, já os 8/27 não autorizariam o compartilhamento, justificando que tratamento médico é sigiloso, que tem direito à privacidade, que tem direito em escolher quem deve saber sobre sua doença ou não. Os 28/27 respondentes consideram que tirar foto filme de paciente é diferente de tirar foto filme de uma paisagem, apenas um disse que não há diferença; 17/27 respondentes acreditam que a divulgação de foto/filme de paciente viola algum 
princípio ético, 9/27 afirma que depende da situação e se não tiver sido autorizado pelo paciente.

Dos 27 estudantes, quatro disseram não saber definir o conceito de autonomia, dois o de privacidade e confidencialidade e quatro o de sigilo. Quanto ao conhecimento de norma ou lei que oriente acerca da divulgação de imagens de pessoas, 22 estudantes afirmaram não conhecer nenhuma.

\subsubsection{ENFERMAGEM}

Os estudantes de enfermagem 12/22 já tiveram contato com pacientes, sete estudantes já tiraram foto de paciente, 13 conhecem alguém que tirou, oito pediram autorização, destas cinco escritas e duas verbais e um estudante disse: "É escrita na primeira vez avisando que vai haver avaliação e que fotos serão tiradas depois é só comunicação verbal mesmo".

Quanto a presença de um supervisor, os oito disseram que haviam professor ou preceptor ou supervisor do hospital. As fotos foram divulgadas no WhatsApp por quatro estudantes, porém apenas um admite que divulgou em redes sociais, enquanto dois afirmam ter apagado, e logo em seguida dizem que as fotos foram compartilhadas; um outro participante disse ter arquivado, e logo na questão seguinte diz que foi publicada no WhatsApp. É perceptível uma forte contradição no decorrer das respostas, caracterizando no decorrer de toda a pesquisa que o discurso é bem diferente da prática.

Dos 11/22 estudantes afirmam que autorizaria o compartilhamento de uma foto ou filme, se fosse o paciente. Todos acreditam que há diferença em tirar foto de uma paisagem e de uma pessoa/paciente, asseguram que enviar fotos/filmes de pacientes para redes sociais viola algum princípio ético, e 15/22 garantem que não conhecem norma ou lei que oriente acerca da divulgação de imagens de pessoas.

\subsubsection{FARMÁCIA}

Dos 11 estudantes do curso de Farmácia, apenas um afirma que já teve contato com paciente. Um outro estudante falou que não teve contato com paciente e na questão seguinte disse que já tirou foto de paciente na clinica da família no 
areal, para trabalho do curso, e expressa que pediu autorização verbal. Garante que apagou a foto depois do uso.

Dos onze, três declaram que conhece alguém que já tirou foto de paciente. Quanto permitir o compartilhamento de uma foto sua enquanto paciente 7/11 estudantes declaram que permitiriam, enquanto outros dois disseram que não, e justificaram que: "Exposição da imagem pessoal em momentos de fraqueza ou fragilidade - ridículo". Já o outro afirma: "Porque não quero que a minha imagem seja exposta para qualquer um".

Dos 11 estudantes,10 consideram que existe diferença de tirar foto ou fazer filme de um paciente e de uma natureza morta, enquanto, um disse que não há diferença. $\mathrm{E}$ se essas fotos ou filmes de pacientes forem enviados para redes sociais se viola algum princípio ético, 9/11 considera que sim, os outros dois ponderaram que se o paciente queria e autorizou, não viola.

De onze estudantes, oito não consegue definir o conceito de autonomia do paciente; Três não conseguiriam definir o conceito de privacidade; quatro não conseguiria definir o conceito de confidencialidade, três não conseguiria definir o conceito de sigilo e 9/11 Garante que não conhece nenhuma norma ou lei que trata acerca da divulgação de imagens de pessoas. 


\subsection{Seria necessário uma formação profissional virtuosa na pós- modernidade?}

As relações humanas são consideradas complexas, e na área de saúde, esse convívio é ainda mais delicado, por isso desde Hipócrates se estabeleceu um juramento de proteção do paciente, tendo em vista ser necessário conhecimento de todos os detalhes da vida de uma pessoa, para possibilitar o diagnostico real da questão. Desta forma, o campo da saúde tem a necessidade de um profissional que tenha características, singulares, que tenha recebido formação moral e técnica que resguarde direitos básicos do paciente e confira humanização e qualidade nas interrelações profissional-paciente-sociedade ${ }^{174}$.

Embora exista a forte presença do principialismo, incorporado inclusive nos códigos deontológicos, diversas autores contemporâneos, como Bauman ${ }^{175} \mathrm{e}$ Maclntyre $^{176}$ elaboram a alternativa de uma ética de virtudes para resguardar a humanidade na contemporaneidade.

Maclntyre ${ }^{176}$ surge na presente discussão por aportar alguns elementos importantes para a formação do profissional de saúde. Em seus trabalhos, sugere que a ética deveria se concentrar menos nos indivíduos e mais na comunidade e em seu bem-estar, estando menos preocupado com o que as pessoas deveriam fazer e sim como elas deverias ser. A tradição aristotélica das virtudes traz a ideia de que as pessoas deveriam ter "boas disposições" em relação aos outros. A fim de fugir da utopia do Bem, Maclntyre ${ }^{176}$ afirma:

(...) só se caracteriza de maneira adequada o comportamento quando se sabe quais são as intenções de prazo mais longo invocadas e como as intenções de prazo mais curto se relacionam com as de prazo mais longo. Novamente nos envolvemos na escrita de uma história narrativa. (p. 349)

Maclntyre, citado por Carvalho ${ }^{177}$, fez um levantamento histórico da "crise moral" originada nos "problemas filosóficos" partindo para o resgate da "ética aristotélica das virtudes" para usar suas adequadas estruturas filosóficas em prol de buscar sanar nossos problemas de moralidade. Lançando mão de elementos teóricos que tenha capacidade de organizar o conceito de virtude adequando-o a atual realidade, para tanto, abandonando os elementos insustentáveis e não pertinentes ao contexto contemporâneo, aderindo se a um conceito de virtude que 
tenha respeito a historicidade intrínseca a ação humana e a sua imprescindível dimensão de comunidade.

O primeiro conceito de virtude de Maclntyre ${ }^{177}$ encontra-se relacionados às práticas, que são construídas ao longo da história, compreendidas pelo "conjunto de atividades sistemáticas", de conhecimento social, onde em seu cerne ampliam-se "critérios de excelência e bens internos a serem alcançados"(p.18)

O segundo, propõe uma visão coesa do "bem humano", considerando a totalidade da vida, de modo à criar hierarquia dos "bens vinculados as práticas". Tal entendimento, provê o "telos" para a atuação "individual e coletiva" no meio das comunidades, organizando as variadas práticas, de forma a construir a "narrativa histórica" que dá a coesão em nossas vidas. Tal visão holística da vida representa criar uma função às virtudes, para que se torne "disposições de caráter" a possibilitar que o bem comum ao ser humano seja praticável, no "enfrentamento das dificuldades, contradições, problemas, seduções e desvios que se apresentam na vida histórica de homens e mulheres (p.19).

O terceiro, trata de que a "narrativa histórica" possibilitada pela crença do "bem humano como tal", que concede a coesão à nossas vidas, é construída numa "tradição social e intelectual" da qual somos integrantes, que:

Nossas narrativas são entrecruzadas pelas dos outros indivíduos que fazem parte da
nossa vida, bem como pelas necessidades e exigências comunitárias ou sociais. As
virtudes vão ter o papel de fazer com que essa busca individual pela realização do
bem último do ser humano não se corrompa, garantindo a sustentação da tradição da
qual partimos, bem como fazer com que essa busca não perca sua dimensão
histórica. Pois o que é esse bem último, esse telos que fornece o horizonte de ação
das tradições morais, é o objeto central de debate interno e externo da tradição, um
debate histórico constitutivo de toda tradição moral viva, no confronto com a
diversidade das tradições rivais que se oferecem na sua existência histórica. ${ }^{177}$

Mariano $\mathrm{Jr}^{165}$ salienta que uma corrente da ética tradicional e da ética médica, que há décadas fora deixada, ressurge, priorizando aspectos positivos dos indivíduos que atuam de modo a ampliarem "suas atitudes e decisões". Diz que segundo Drane, nos Estados Unidos tem buscado criar uma "ética médica da virtude", empregada na relação "médico-paciente", em que interajam: grandezas da medicina, afetivas, de ordem espiritual, social, "voluntárias e religiosas". De tal modo, que os assuntos da moralidade em Medicina e no atendimento em saúde precisarão ser debatidos fundamentados nas virtudes e no caráter, uma vez que grande parte dos profissionais da saúde pode desviar-se com facilidade da estrutura de normas e dos Códigos de Ética que podem possuírem lacunas. 
As diferentes especialidades do campo da saúde têm procurado estabelecer uma sociedade moral, em que são realizadas discussões a respeito do bem comum e prestada satisfação a respeito das virtudes que são demandadas dentro dela ${ }^{165}$. $\mathrm{Na}$ definição das virtudes, a razão humana é responsável pelas chamadas virtudes Naturais, enquanto as virtudes supranaturais tem na sua essência a junção de razão e fé. Ambas, "as virtudes naturais e as supranaturais" atualmente compõem parte do que chama-se de "Ética das Virtudes", a qual estipula o "tipo de pessoa que devemos ser: a pessoa virtuosa, inclinada a fazer 0 bem e o certo, independentemente das circunstâncias"165 (p.192). Assim, a ética das Virtudes, segundo Mariano ${ }^{165}$ citando Pellegrino ${ }^{178}$ é definida "como o traço de caráter que predispõe seu possuidor habitualmente à excelência de intenções e desempenho em relação ao telos específico para uma atividade humana"(p.196).

A ética das virtudes, o modelo mais antigo de filosofia moral, destaca a importância do caráter da pessoa na tomada de decisões éticas. Os profissionais de saúde que regem os seus atos segundo uma perspectiva ética das virtudes, não irão participar em certas atividades questionáveis do ponto de vista ético, acerca das quais a lei e os códigos deontológicos possam ser omissos ou condescendentes $(\text { p.110 })^{152}$.

Um conveniente código deontológico contribui para uma possibilidade de avaliação racional, uma vez que exprime perspectivas éticas. Entretanto, o comprometimento de ser profissional de saúde vai além da adoção de um conjunto de normas exteriores, pois é um comprometimento interior, bem como é a "conversão dos religiosos". O jovem acadêmico passa pelo processo de conversão em profissional, algumas vezes de modo gradual e devagar, outras vezes subitamente, por meio da consciência ${ }^{179}$. Outro recurso capaz de auxiliar na busca da virtude é a aprendizagem de exemplos clínicos junto a professores mais experientes que possam traduzir as vivências morais em cada situação para o acadêmico e demonstrar quais seriam as atitudes desejáveis para a formação de um bom médico. Tal estudo casuístico das virtudes e atitudes necessárias, junto a um bom professor de ética médica e bioética, pode colaborar sobremaneira na formação médica"(p.3). ${ }^{179}$

$\mathrm{Cruz}^{152}$, se apropriando dos argumentos de Pellegrino, pondera que a sociedade contemporânea precisa de profissionais de saúde que, "além de serem tecnicamente competentes, sejam compassivos e instruídos, que possam entender 
como o seu trabalho se relaciona com a cultura de que fazem parte, e que possam lidar com empatia com outros seres humanos em sofrimento" (p.110).

Trazendo Bauman ${ }^{180}$ novamente para a discussão:

a qualidade da sociedade deve ser testada pelos critérios de justiça e de fair play que regulamentam a coletividade humana: a sociedade deve se justificar pelos padrões éticos, e não o contrário, os padrões éticos pela sociedade. Espero ter o direito de dizer que nunca abandonei essa crença. 


\section{CONSIDERAÇÕES FINAIS}

A presente pesquisa foi realizada por meio de questionário semiestruturado com questões que teve como propósito conhecer a percepção ética de estudantes da área de saúde sobre o uso de imagens e/ou vídeos, bem como de informações de pacientes e sua exposição em meios sociais, assim como discutir à luz da Declaração Universal sobre Bioética e Direitos Humanos, os resultados encontrados.

Ultimamente os serviços de atendimento em saúde são constituídos por equipe multiprofissional de assistência, bem como técnicos de saúde e agentes da administração, em que há necessidade de compartilhamento de informações entre os profissionais, entretanto, essas trocas devem-se restringir somente as que se fizerem necessárias ao bom desempenho do atendimento ao paciente.

Estas unidades de saúde também se constituem em espaços de aprendizagem, onde estudantes, profissionais, professores e pacientes convivem. E estas relações são afetadas pela crise da ética que oriunda da racionalidade técnica e paternalista que se estabeleceu nestas unidades, o que significa que os direitos dos pacientes, a despeito de toda retórica de humanização existente, são frequentemente violados por práticas corriqueiras, tais quais a obtenção de fotografias e vídeos, que atendem quase que exclusivamente aos interesses daquele que obteve a imagem.

Conforme constatado na pesquisa, esta situação se agrava pela comprovação da tese levantada no presente trabalho: que estudantes obtém imagens de pacientes, com ou sem consentimento, e as fazem circular em espaços distintos daqueles diretamente relacionadas com o atendimento do paciente, configuradas na presente pesquisa, como as redes sociais virtuais.

Apesar da maioria dos estudantes entrevistados relatar que não obtém imagens de pacientes, também denunciam que esta é uma prática corriqueira por parte daqueles que os cercam. E quando arguidos a respeito de tais práticas, parecem não compreender bem os conceitos de autonomia, privacidade $\mathrm{e}$ confidencialidade. Também destacaram a importância da formação ética-profissional para que os abusos sejam evitados.

Estas paradoxais constatações reforçam a necessidade de ampliar os espaços de formação em bioética, estimulando que seu campo de ação e reflexão crítica se estendam para os espaços clínicos e semestre mais avançados dos 
estudantes do campo da saúde. Neste sentido, cabe reforçar a importância de documentos como a DUBDH, que trazem um background de bioética crítica que se dispõe a reduzir a vulnerabilidade e toda forma de vulneração do ser humano.

Assim, a bioética ao trabalhar moralidades plurais e preocupar-se com aqueles que são mais frágeis, apresenta-se como espaço adequado de debate dos conflitos que se apresentam na relação entre pacientes e profissionais de saúde, quanto à propriedade das informações e a garantia do sigilo, privacidade e confidencialidade da imagem e das informações pessoais dos pacientes.

Compreende-se portanto, no presente trabalho que a formação em Bioética de professores e estudantes de saúde, orientada por normativas que preconizam a defesa de direitos humanos e pela prática virtuosa, constitui uma necessidade irrevogável para evitar os abusos aqui apresentados: a invasão do espaço privado do paciente, o desrespeito a sua autonomia em escolher o que deve ser feito com sua imagem, a aparente desimportância atribuída por tutores e professores ao fato de seus estudantes estarem violando normativas éticas e direitos humanos. 


\section{REFERÊNCIAS}

1. Possolli GE, do Nascimento GL, da Silva JOM. A Utilização do Facebook no Contexto Acadêmico: o Perfil de Utilização e as Contribuições Pedagógicas e para Educação em Saúde. RENOTE. 2015;13(1).

2. Dancy J. An ethic of prima facie duties. A companion to ethics. 1991:219-29.

3. Ross WD. Prima facie duties. In: Gowans CW, editor. Moral Dilemmas. Oxford: Oxford Uiversity Press; 1987.

4. Michael DN. Speculations on the Relation of the Computer to Individual Freedom and the Right to Privacy. George Wash Law Rev. 1964;33(1):270-86.

5. Berkley C. Privacy and the patients' right to information. Medical research engineering. 1971 Jan-Feb;10(1):3 passim.

6. Boyer BB. Computerized medical records and the right to privacy: the emerging federal response. Buffalo law review. 1975 Fall;25(1):37-118.

7. Wilberding JC. Privacy: patients' medical records and insurance. I. The right of privacy and the medical information bureau. Transactions \& studies of the College of Physicians of Philadelphia. 1975 Apr;42(4):375-81.

8. Dreyer JL. Right to Privacy - Responsibility of Industry - Position Paper by Association-of-Data-Processing-Service-Organizations (Adapso). Comput People. 1976;25(3):24-.

9. Willy FJ. Right to privacy in personal medical information. Medical trial technique quarterly. 1977 Fall;24(2):164-83.

10. Creighton $\mathrm{H}$. The diminishing right of privacy: computerized medical records. Law for the nurse supervisor. Supervisor nurse. 1978 Feb;9(2):58-61.

11. Hiller MD. Computers, medical records, and the right to privacy. Journal of health politics, policy and law. 1981 Fall;6(3):463-87.

12. Feldberg M. The electronic hospital chart and the right to privacy. Medicine and law. 1986;5(4):289-92.

13. Banach J, Todd J, Krispin KT, O'Leary D. Right to privacy vs. right to know. Interview by Stuart A. Westbury, Jr. Healthcare executive. [Interview]. 1987 Jul-Aug;2(4):516.

14. Barrows Jr RC, Clayton PD. Privacy, confidentiality, and electronic medical records. Journal of the American Medical Informatics Association. 1996;3(2):139.

15. Campbell SG, Gibby GL, Collingwood S. The Internet and electronic transmission of medical records. Journal of clinical monitoring. 1997 Sep;13(5):325-34.

16. McDougall R, Notini L, Phillips J. Conflicts Between Parents and Health Professionals About a Child's Medical Treatment: Using Clinical Ethics Records to Find Gaps in the Bioethics Literature. Journal of bioethical inquiry. [Research Support, Non-U.S. Gov't]. 2015 Sep;12(3):429-36.

17. Milton CL. Information sharing: transparency, nursing ethics, and practice implications with electronic medical records. Nursing science quarterly. 2009 Jul;22(3):214-9. 18. Willison DJ, Emerson C, Szala-Meneok KV, Gibson E, Schwartz L, Weisbaum KM, et al. Access to medical records for research purposes: varying perceptions across research ethics boards. Journal of medical ethics. [Research Support, Non-U.S. Gov't]. 2008 Apr;34(4):308-14.

19. Recupero PR. Ethics of medical records and professional communications. Child and adolescent psychiatric clinics of North America. [Review]. 2008 Jan;17(1):37-51, viii.

20. Sarre SG. Forum on ethics. Group practice, medical records, and the patients. Texas medicine. 1999 May;95(5):28-9. 
21. França GVd. Telemedicina: breves considerações ético-legais. Revista Bioética. 2009;8(1):107-26.

22. West JC. Patients whose records were posted in the Internet can bring class action lawsuit. Tabata v. Charleston Area Medical Center, Inc. Journal of healthcare risk management : the journal of the American Society for Healthcare Risk Management. 2015;35(1):43-4.

23. Legazpi AR. The right to privacy and the limits on obtaining evidence: the tracking of computers (incoming records from eMule) in constitutional court ruling 173/2011, 7th November. Rev Esp Derecho Cons. 2014 Jan-Apr;34(100):365-90.

24. Rakovac I, Seereiner S, Ratz B, Habacher W, Pieber TR, Beck P. Use of personal computers, electronic medical records and availability of Internet among office based GPs and internists in Austrian province of Styria. AMIA Annual Symposium proceedings / AMIA Symposium AMIA Symposium. 2008:1102.

25. Maglogiannis I, Constantinos D, Kazatzopoulos L. Enabling collaborative medical diagnosis over the Internet via peer-to-peer distribution of electronic health records. Journal of medical systems. 2006 Apr;30(2):107-16.

26. Bauer K. Electronic medical records and the internet. The virtual mentor : VM. 2001;3(3).

27. Robinson JK, Bhatia AC, Callen JP. Protection of patients' right to privacy in clinical photographs, video, and detailed case descriptions. JAMA dermatology. [Editorial]. 2014 Jan;150(1):14-6.

28. Moubarak G, Guiot A, Benhamou Y, Benhamou A, Hariri S. Facebook activity of residents and fellows and its impact on the doctor-patient relationship. Journal of medical ethics. $2011 \mathrm{Feb}$;37(2):101-4.

29. Garner J, O'Sullivan H. Facebook and the professional behaviours of undergraduate medical students. The clinical teacher. [Research Support, Non-U.S. Gov't]. 2010 Jun;7(2):112-5.

30. Summers J. Patients' right to privacy abused. Nursing New Zealand. [Comment Letter]. 2006 Jul;12(6):3-4.

31. Kennedy WC, Jacobs E. Literature review of legal aspects of medical records. Topics in health record management. [Review]. 1981 Jun;1(4):19-32.

32. Zahabi M, Kaber DB, Swangnetr M. Usability and Safety in Electronic Medical Records Interface Design: A Review of Recent Literature and Guideline Formulation. Human factors. [Research Support, N.I.H., Extramural

Research Support, Non-U.S. Gov't

Review]. 2015 Aug;57(5):805-34.

33. Dean BB, Lam J, Natoli JL, Butler Q, Aguilar D, Nordyke RJ. Review: use of electronic medical records for health outcomes research: a literature review. Medical care research and review : MCRR. [Review]. 2009 Dec;66(6):611-38.

34. La Sala L, Skues J, Wise L. What do we mean by social networking sites? Studies in health technology and informatics. 2014;199:108-12.

35. Moubarak G, Guiot A, Benhamou Y, Benhamou A, Hariri S. Facebook activity of residents and fellows and its impact on the doctor-patient relationship. Journal of medical ethics. 2011 February 1, 2011;37(2):101-4.

36. Martorell LB, Nascimento WFd, Garrafa V. Redes sociais, privacidade, confidencialidade e ética: a exposição de imagens de pacientes no facebook. Interface Comunicação, Saúde, Educação. 2016;20:13-23.

37. Estatística IBdGe. Pesquisa Nacional por Amostra de Domicílios 2008: notas metodológicas pesquisa básica, pesquisa especial de tabagismo e pesquisas suplementares de 
saúde e acesso à internet e posse de telefone móvel celular para uso pessoal. Instituto Brasileiro de Geografia e Estatística Rio de Janeiro; 2009.

38. Gauthier TP, Spence E. Instagram and Clinical Infectious Diseases. Clinical infectious diseases : an official publication of the Infectious Diseases Society of America. [Comment Letter]. 2015 Jul 1;61(1):135-6.

39. Acquisti A, Gross R, editors. Imagined communities: Awareness, information sharing, and privacy on the Facebook. Privacy enhancing technologies; 2006: Springer.

40. Nakhasi A, Bell SG, Passarella RJ, Paul MJ, Dredze M, Pronovost PJ. The Potential of Twitter as a Data Source for Patient Safety. Journal of patient safety. 2016 Jan 11.

41. Waldrop J, Wink D. Twitter: An Application to Encourage Information Seeking Among Nursing Students. Nurse educator. 2015 Dec 15.

42. Jacobs MA, Cha S, Villanti AC, Graham AL. Using Tumblr to Reach and Engage Young Adult Smokers: A Proof of Concept in Context. American journal of health behavior. 2016 Jan;40(1):48-54.

43. Barchiesi D, Moat HS, Alis C, Bishop S, Preis T. Quantifying International Travel Flows Using Flickr. PloS one. [Research Support, Non-U.S. Gov't]. 2015;10(7):e0128470.

44. Engelstad ME, McClellan M, Jacko JA, Melton GB. Deidentification of facial images using composites. Journal of oral and maxillofacial surgery : official journal of the American Association of Oral and Maxillofacial Surgeons. [Research Support, Non-U.S. Gov't]. 2011 Dec;69(12):3026-31.

45. Tarcinale MA. Medical photographer's role in protecting a patient's right to privacy. Journal of biological photography. 1980 Oct;48(4):183-5.

46. Stevens GE. Medical photography, the right to privacy and privilege. Medical trial technique quarterly. 1978 Spring;24(4):456-64.

47. UNESCO. Declaração Universal sobre Bioética e Direitos Humanos da Unesco. Tradução: Tapajós A, Prado MM, Garrafa V ed. Brasília: Cátedra UNESCO de Bioética; 2005.

48. Bauman Z, Donskis L. Cegueira Moral: a perda da sensibilidade na modernidade líquida. 1 ed. Rio de Janeiro: Zahar; 2014.

49. Bauman Z. Vida líquida. 2 ed. Rio de Janeiro: Zahar; 2007.

50. Bauman Z. Modernidade líquida. Rio de Janeiro: Jorge Zahar Editor; 2001.

51. Bauman Z. Entrevista com o filósofo polonês Zygmunt Bauman para o Fronteiras do Pensamento. Fronteiras do Pensamento. Brasil2012.

52. Rocha-de-Oliveira S, Piccinini VC, Bitencourt BM. Juventudes, gerações e trabalho: É possível falar em geração Y no Brasil? Organizações \& Sociedade. 2012;19(62):551-8.

53. Veloso EFR. É possível negar a existência da geração Y no Brasil? Organizações \& Sociedade. 2012;19(63):745-7.

54. Yang CC, Bradford Brown B. Online Self-Presentation on Facebook and Self Development During the College Transition. Journal of youth and adolescence. 2016 Feb;45(2):402-16.

55. Krishnan A, Hunt DS. Influence of a multidimensional measure of attitudes on motives to use social networking sites. Cyberpsychology, behavior and social networking. 2015 Mar;18(3):165-72.

56. Khumsri J, Yingyeun R, Mereerat M, Hanprathet N, Phanasathit M. Prevalence of Facebook Addiction and Related Factors Among Thai High School Students. Journal of the Medical Association of Thailand = Chotmaihet thangphaet. [Research Support, Non-U.S. Gov't]. 2015 Apr;98 Suppl 3:S51-60.

57. Mezrich JL, Siegel E. Who owns the image? Archiving and retention issues in the digital age. Journal of the American College of Radiology : JACR. 2014 Apr;11(4):384-6. 
58. Foucault M. As palavras e as coisas: uma arqueologia das ciências humanas. 10 ed. São Paulo: Martins Fontes; 2007.

59. Castells M. A Sociedade em Rede. Lisboa: Fundação Calouste Gulbenkian; 2002.

60. Medical-Practice and the Right to Privacy. Minn Law Rev. 1959;43(5):943-63.

61. Berkley C. Privacy and Patients Right to Information. Medical research engineering. $1971 ; 10(1): 3-\&$.

62. Hayward SG. Constitutional Law - Abortion - Statutory Limitation on Reasons for Abortion Is Violation of Fundamental Right to Privacy. Mercer law review. 1971;22(1):4616.

63. Wheeler LA, Kovar SL. roe v. Wade: the right of privacy revisited. University of Kansas law review University of Kansas School of Law. 1973 Summer;21(4):527-48.

64. Haley JN. Haunting shadows from the rubble of Roe's right of privacy. Suffolk University law review. 1974 Fall;9(1):145-84.

65. Sirkis JE. A lesson in judicial abdication: Roe v. Arizona Board of Regents and the right of privacy. Arizona State law journal. 1976;1976(3):499-524.

66. Shefler AJ. Indigent women and abortion: limitation of the right of privacy in Maher v. Roe. Tulsa law journal. 1977;13(2):287-303.

67. Siliciano JA. The minor's right of privacy: limitations on state action after Danforth and Carey. Columbia law review. 1977 Dec;77(8):1216-46.

68. Smith PA. The right to privacy: Roe v. Wade revisited. Jurist. 1983;43(2):289-317.

69. Barnard D, et al. The evolution of the right to privacy after Roe v. Wade. American journal of law \& medicine. 1987;13(2 3):365-525.

70. Clement S, Goldstein L, Krauss LB, Maio DA, Reske S, Ravitz W, et al. The Evolution of the Right to Privacy after Roe V Wade. American journal of law \& medicine. 1987;13(2-3):365-525.

71. Solis PP. The Patient's Right of Privacy. Journal of the Philippine Medical Association. 1965 Jan;41:75-8.

72. Whitaker LT. "The right of privacy". Journal of the Medical Association of Georgia. 1963 May;52:225-6.

73. Slovenko R, Usdin GL. Privileged Communication and Right of Privacy in Diagnosis and Therapy. Current psychiatric therapies. 1963;3:277-319.

74. Cahal MF, Cady EL, Jr. Right of privacy. Gp. 1962 Dec;26:176-7.

75. Regan WA. The legal right of privacy. III. Hospital progress. 1958 Jun;39(6):90-2.

76. Regan WA. The legal right of privacy. I. Hospital progress. 1958 Apr;39(4):76-8 passim.

77. PATIENT'S right to privacy. Journal of the American Medical Association. 1957 Sep 14;165(2):167-8.

78. Ashley JW. Dissemination of fingerprints before conviction as an invasion of the right of privacy. The Journal of criminal law and criminology, including the American journal of police science. 1947 Nov-Dec;38(4):440.

79. ONU. Declaração Universal dos Direitos Humanos. In: Unidas AGdN, editor. Genebra1948.

80. Vianna TL. Transparência pública, opacidade privada: o direito como instrumento de limitação do poder na sociedade de controle. Rio de Janeiro: Revan; 2007.

81. de Carvalho Fortes PA. Ética, direitos dos usuários e políticas de humanização da atenção à saúde. Saúde e Sociedade. 2004;13(3):30-5.

82. Payne D. GOOGLE, DOCTORS, AND THE "RIGHT TO BE FORGOTTEN" Details of doctors' registration status on the GMC website. Bmj-Brit Med J. 2015 Jan 28;350.

83. Wronski K. Patients right to privacy during medical services. Wspolczesna Onkol. 2008 Jul;12(4):201-3. 
84. Barilan YM, Brusa M. Human rights and bioethics. Journal of medical ethics. 2008 May;34(5):379-83.

85. Loughrey J. Medical information, confidentiality and a child's right to privacy. Legal studies. 2003 Sep;23(3):510-35.

86. Bauman Z. 44 cartas do mundo líquido moderno. 1 ed. Rio de Janeiro: Zahar; 2011.

87. Bauman Z. Identidade: entrevista a Benedetto Vecchi. Tradução ed. Rio de Janeiro2005.

88. Mitchell KJ, Ybarra M. Social networking sites: finding a balance between their risks and benefits. Archives of pediatrics \& adolescent medicine. [Comparative Study

Editorial]. 2009 Jan;163(1):87-9.

89. Fuld GL. Social networking and adolescents. Adolescent medicine: state of the art reviews. [Review]. 2009 Apr;20(1):57-72, viii.

90. Raacke J, Bonds-Raacke J. MySpace and Facebook: applying the uses and gratifications theory to exploring friend-networking sites. Cyberpsychology \& behavior : the impact of the Internet, multimedia and virtual reality on behavior and society. 2008 Apr;11(2):169-74.

91. Peluchette J, Karl K. Social networking profiles: an examination of student attitudes regarding use and appropriateness of content. Cyberpsychology \& behavior : the impact of the Internet, multimedia and virtual reality on behavior and society. 2008 Feb;11(1):95-7.

92. Starcevic V, Aboujaoude E. Cyberchondria, cyberbullying, cybersuicide, cybersex: "new" psychopathologies for the 21st century? World psychiatry : official journal of the World Psychiatric Association. 2015 Feb;14(1):97-100.

93. Machold C, Judge G, Mavrinac A, Elliott J, Murphy AM, Roche E. Social networking patterns/hazards among teenagers. Irish medical journal. 2012 May;105(5):151-2.

94. Kittinger R, Correia CJ, Irons JG. Relationship between Facebook use and problematic Internet use among college students. Cyberpsychology, behavior and social networking. 2012 Jun;15(6):324-7.

95. Anjos MFd, Fortes PAdC. Desafios para a preservaçäo da privacidade no contexto da saúde. Bioética. 2000;8(2):307-22.

96. Francisconi CF, Goldim JR. Aspectos bioéticos da confidencialidade e privacidade. Iniciação à bioética Brasília: Conselho Federal de Medicina. 1998:264-84.

97. Cohen C, Segre M, Cohen C. A confidencialidade: questões éticas relativas ao segredo profissional1999.

98. Zoboli E, PAC F. Bioética e atenção básica: um perfil dos problemas éticos vividos por enfermeiros e médicos do Programa Saúde da Família, São Paulo, Brasil. Cadernos de saude publica. 2004;20(6):1690-9.

99. Seoane AF, de Carvalho Fortes PA. A percepção do usuário do Programa Saúde da Família sobre a privacidade e a confidencialidade de suas informações. Saúde e Sociedade. 2009; 18(1):42-9.

100. Massarollo M, Saccardo D, Zoboli E. Autonomia, privacidade e confidencialidade. Oguisso T; Zoboli ELCP Ética e Bioética: Desafios para a Enfermagem e a Saúde São Paulo: Manole. 2006:137-9.

101. de Azambuja Loch J. Confidencialidade: natureza, características e limitações no contexto da relação clínica. Revista Bioética. 2009;11(1).

102. Loch JdA, Clotet J, Goldim JR. Privacidade e confidencialidade na assistência à saúde do adolescente: percepções e comportamentos de um grupo de 711 universitários. Rev Assoc Med Bras. 2007;53(3):240-6.

103. da Silva LT, Zoboli ELCP, Borges ALV. Bioética e atenção básica: um estudo exploratório dos problemas éticos vividos por enfermeiros e médicos no PSF. Cogitare Enfermagem. 2006;11(2). 
104. Soares NV, Dall'Agnol CM. Privacidade dos pacientes: uma questão ética para a gerência do cuidado em enfermagem. Acta paulista de enfermagem Vol 24, n 5 (set/out 2011), p 683-688. 2011.

105. Saito MI, Leal MM, Silva L. A confidencialidade no atendimento à saúde de adolescentes: princípios éticos. Pediatria. 1999;21(2):112-6.

106. de Mello Abdalla FT, Nichiata LYI. A Abertura da privacidade e o sigilo das informações sobre o HIV/Aids das mulheres atendidas pelo Programa Saúde da Família no município de São Paulo, Brasil. Saúde e Sociedade. 2008;17(2):140-52.

107. dos Santos MdFO, dos Santos TEO, dos Santos ALO. A confidencialidade médica na relação com o paciente adolescente: uma visão teórica. Revista Bioética. 2012;20(2):318-25.

108. Cunha L, Patrício ZM. Confidencialidade e privacidade em planos de saúde. Revista Bioética. 2008;16(1).

109. Castiel LD. Insegurança, ética e comunicação em saúde pública. Revista de Saúde Pública. 2003;37(2):161-7.

110. Bauman Z. A sociedade individualizada: vidas contadas e histórias vividas. 1 ed. Rio de Janeiro: Zahar; 2008.

111. Dupas G. Ética e poder na sociedade da informação: de como a autonomia das novas tecnologias obriga a rever o mito de progresso. 3 ed. São Paulo: Editora Unesp; 2011.

112. Ursin LO. Biobank research and the right to privacy. Theoretical medicine and bioethics. 2008;29(4):267-85.

113. Tisseyre S. [The right to privacy: a donor's identity of donated gametes]. Journal international de bioethique = International journal of bioethics. 2015 Jul;26 Spec no:131-7.

114. Forster HP. Legal trends in bioethics. The Journal of clinical ethics. [Review]. 1999 Summer;10(2):156-65.

115. ALLEN AL. PRIVACY IN HEALTHCARE. In: Post SG, editor. Encyclopedia of bioethics. 3 ed. New York: Macmillan Reference 2004. p. 2120-30.

116. Anjos MFd. Desafios para a preservação da privacidade no contexto da saúde. Secções - Temas em debate. Revista Bioética. 2009;12(1):307-22.

117. Luciano EM, Bragança CEB, Testa MG. Privacidade de informações de pacientes de instituiçoes de saúde: a percepção de profissionais da área de saúde. Reuna. 2011;16(2).

118. Faria JB, Cruz MR, Fernandes A, Dolores SEMF. Bioética, religião e promessas de cura: reflexões sobre o princípio da autonomia. Revista Brasileira de Bioética. 2008;4(12):97-117.

119. Durand G. Introdução geral à bioética. 193-202 ed. São Paulo: Edicoes Loyola; 2003.

120. McKee R. Ethical issues in using social media for health and health care research. Health policy. 2013 May;110(2-3):298-301.

121. BAUDRILLARD J. Senhas, Tradução de Maria Helena Kuhner. Rio de Janeiro: DIFEL. 2001.

122. Baudrillard J. Simulacros e simulações. Lisboa: Relógio d'água. 1991.

123. Selkie EM, Fales JL, Moreno MA. Cyberbullying Prevalence Among US Middle and High School-Aged Adolescents: A Systematic Review and Quality Assessment. The Journal of adolescent health : official publication of the Society for Adolescent Medicine. [Review]. $2016 \mathrm{Feb} ; 58(2): 125-33$.

124. Pabian S, Vandebosch H. An Investigation of Short-Term Longitudinal Associations Between Social Anxiety and Victimization and Perpetration of Traditional Bullying and Cyberbullying. Journal of youth and adolescence. 2016 Feb;45(2):328-39.

125. Walker M, Thornton L, De Choudhury M, Teevan J, Bulik CM, Levinson CA, et al. Facebook Use and Disordered Eating in College-Aged Women. The Journal of adolescent health : official publication of the Society for Adolescent Medicine. [Research Support, N.I.H., Extramural]. 2015 Aug;57(2):157-63. 
126. Spears BA, Taddeo CM, Daly AL, Stretton A, Karklins LT. Cyberbullying, helpseeking and mental health in young Australians: implications for public health. International journal of public health. [Research Support, Non-U.S. Gov't]. 2015 Feb;60(2):219-26.

127. Runions KC, Bak M. Online Moral Disengagement, Cyberbullying, and CyberAggression. Cyberpsychology, behavior and social networking. 2015 Jul;18(7):400-5.

128. Newman AL. What the "right to be forgotten" means for privacy in a digital age. Science. 2015 Jan 30;347(6221):507-8.

129. Hottois G, Parizeau M-H. Dicionário da Bioética. Lisboa: Istituto Piaget; 1993.

130. WHO. Ethics in epidemics, emergencies and disasters: research, surveillance and patient care: training manual: World Health Organization; 2015. Available from: http://apps.who.int/iris/bitstream/10665/196326/1/9789241549349_eng.pdf?ua=1.

131. de Azambuja Loch J. Confidencialidade: natureza, características e limitações no contexto da relação clínica. Revista Bioética. 2009;11(1):51-64.

132. Cohen C, Segre Claudio M, Cohen. A confidencialidade: questões éticas relativas ao segredo profissional. 2002. p. 193-200.

133. Goldman EB. Confidentiality and the Tarasoff case. Progress in clinical and biological research. 1980;38:237-44.

134. Naves N. A medicina para além das normas: Reflexões sobre o novo Código de Ética Médica. Brasília: Conselho Federal de Medicina; 2010.

135. Miranda G. Médicos expõem pacientes em redes sociais. Folha de São Paulo. 2014;20/08/2014.

136. Gonçalves ER, Verdi MIM. Os problemas éticos no atendimento a pacientes na clínica odontológica de ensino. Ciência \& Saúde Coletiva. 2007;12(3):755-64.

137. Nogueira PL. ESTATUTO da Criança e do Adolescente Comentado: Lei n. 8.069, de 13 de Julho de 1990: Editora Saraiva; 1991.

138. Barbosa S. A participação brasileira na construção da Declaração Universal sobre Bioética e Direitos Humanos da Unesco. Revista Brasileira de Bioética. 2006;2(4):423-42.

139. Garrafa V. Ampliação e politização do conceito internacional de bioética. Revista Bioética. 2012;20(1):9-20.

140. Caetano R, Garrafa V. Comunicação como ferramenta para divulgar e promover a Declaração Universal sobre Bioética e Direitos Humanos. Revista Bioética. 2014;22(1):34-44. 141. de Oliveira AAS. Interface entre bioética e direitos humanos: o conceito ontológico de dignidade humana e seus desdobramentos. Revista Bioética. 2009;15(2).

142. Costa SIF, Garrafa V, Oselka G. Iniciação à bioética. 1 ed: Conselho Federal de Medicina; 1998.

143. Garay OE. Derecho de los pacientes. In: Tealdi JC, editor. Diccionario latinoamericano de bioética. 1 ed. Bogota: Universidad Nacional de Colombia; 2008. p. 24953.

144. Schramm FR. Finitude e bioética do fim da vida. Rev Bras Cancerol. 2012;58(1):73-8.

145. Sánchez AIM, Bertolozzi MR. Pode o conceito de vulnerabilidade apoiar a construção do conhecimento em Saúde Coletiva. Ciência \& Saúde Coletiva. 2007;12(2):319-24.

146. Figueiredo AM, Souza SRG. Como Elaborar Projetos, Monografias, Dissertações e Teses. 2 ed: Ed. Lumen Juris; 2008.

147. Ferreira R, Peret Filho L, Goulart E, Valadão M. O estudante de medicina da Universidade Federal de Minas Gerais: perfil e tendências. Rev Assoc Med Bras. 2000;46(3):224-31.

148. Taquette SR, Rego S, Schramm FR, Soares LL, Carvalho SV. SITUAÇÕES ETICAMENTE CONFLITUOSAS VIVENCIAD AS POR ESTUDANTES DE MEDICINA. Rev Assoc Med Bras. 2005;51(1):23-8. 
149. Almeida J. Da moral paternalista ao modelo de respeito à autonomia do paciente: os desafios para o ensino da ética médica. Rev Bras Educ Méd. 2000;24(1):27-30.

150. Cohen C, Marcolino JAM. Relaçäo médico-paciente: autonomia e paternalismo. Coleçäo Fac Med-USP: Edusp; 1995. p. 62.

151. Siqueira JEd. O ensino da ética no curso de medicina. O MUNDO DA SAÚDE. 2009;33(1):8-20.

152. Cruz J. O ensino de uma ética das virtudes nas escolas médicas. Rev Bioet Latinoam. 2013;12:108-17.

153. Kottow MH. Enseñanza de la Bioética: una síntesis. Rev bras educ méd. 2009;33(4):658-63.

154. Frazier B, Culley JM, Hein LC, Williams A, Tavakoli AS. Social networking policies in nursing education. Computers, informatics, nursing : CIN. 2014 Mar;32(3):110-7.

155. Bohrod MG, Gibson HL. Photography in medical research. Medical research, a symposium 1946;5:128-57.

156. Power HD. Photography in Relation to the Medical Sciences. California state journal of medicine. 1914 Sep;12(9):383-7.

157. Harting MT, DeWees JM, Vela KM, Khirallah RT. Medical photography: current technology, evolving issues and legal perspectives. International journal of clinical practice. 2015 Apr;69(4):401-9.

158. Papier A. New frontiers in medical photography: teaching and patient care. Skinmed. 2003 Jan-Feb;2(1):52-2.

159. Gupta S, Singh S, Dhaliwal U. Visible Facebook profiles and e-professionalism in undergraduate medical students in India. Journal of educational evaluation for health professions. 2015 Oct 31.

160. Leger MC, Wu T, Haimovic A, Kaplan R, Sanchez M, Cohen D, et al. Patient perspectives on medical photography in dermatology. Dermatologic surgery : official publication for American Society for Dermatologic Surgery [et al]. [Multicenter Study]. 2014 Sep;40(9):1028-37.

161. Henry RK, Molnar AL. Examination of social networking professionalism among dental and dental hygiene students. Journal of dental education. 2013 Nov;77(11):1425-30.

162. Costantino G, Martinelli F, Sgandurra D. Are Photos On Social Networks Really Private? Proceedings of the 2013 International Conference on Collaboration Technologies and Systems (Cts). 2013:162-5.

163. MacDonald J, Sohn S, Ellis P. Privacy, professionalism and Facebook: a dilemma for young doctors. Medical education. [Research Support, Non-U.S. Gov't]. 2010 Aug;44(8):80513.

164. Supe A. Ethical considerations in medical photography. Issues in medical ethics. 2003 Jul-Sep;11(3):83-4.

165. Marino Jr R. Edmund Pellegrino: ícone da Bioética Cristã. Rev Bioethicos - Cent Univ São Camilo. 2013;7(2):190-8.

166. Russell MJ. Teaching civility to undergraduate nursing students using a virtue ethicsbased curriculum. The Journal of nursing education. 2014 Jun;53(6):313-9.

167. Holland S. The virtue ethics approach to bioethics. Bioethics. 2011 May;25(4):192201.

168. Goldberg D. Pragmatism and virtue ethics in clinical research. The American journal of bioethics : AJOB. [Comment]. 2008 Apr;8(4):43-5.

169. de Siqueira JE, Sakai MH, Eisele RL. O ensino da ética no curso de medicina: a experiencia da Universidade estadual de Londrina (UEL). Revista Bioética. 2009;10(1).

170. Siqueira BPd. A ética do estudante de medicina. Desafios éticos: Conselho Federal de Medicina; 1993. p. 125-30. 
171. Beals DA. Virtue ethics in a pluralistic world. Seminars in pediatric surgery. [Review]. 2001 Nov;10(4):179-85.

172. Jansen LA. The virtues in their place: virtue ethics in medicine. Theoretical medicine and bioethics. [Review]. 2000;21(3):261-76.

173. Benner P. A dialogue between virtue ethics and care ethics. Theoretical medicine. [Historical Article]. 1997 Mar-Jun;18(1-2):47-61.

174. Rego S, Gomes AP, Siqueira-Batista R. Bioética e humanização como temas transversais na formação médica. Rev Bras Educ Méd. 2008;32(4):482-91.

175. Bauman Z. Bauman sobre Bauman: diálogos com Keith Tester. 1 ed: Zahar; 2011.

176. MacIntyre AC. Depois da virtude: um estudo em teoria moral. Bauru: Edusc; 2001.

177. Carvalho HBA. Comunidade moral e política na ética das virtudes de Alasdair MacIntyre. ethic@-An international Journal for Moral Philosophy. 2007;6(3):17-30.

178. Pellegrino ED. The virtues in medical practice. 1993.

179. NETO HA. Editorial: Teaching Medical Virtues Editorial: Ensinando Virtudes Médicas.

180. Pallares-Burke MLG. Entrevista com Zigmunt Bauman. Tempo Social. 2004;16:30125 . 


\title{
ANEXO - A Termo de Consentimento Livre e Esclarecido - TCLE
}

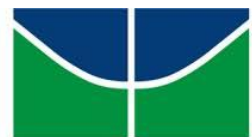 \\ Universidade de Brasília \\ Faculdade de Ciências da Saúde \\ Programa de Pós-Graduação Mestrado e Doutorado em Bioética \\ Termo de Consentimento Livre e Esclarecido - TCLE
}

Convidamos o(a) senhor(a) a participar do projeto de pesquisa intitulado "Análise Bioética da Utilização de imagens de Pacientes em Mídias Sociais Eletrônicas", sob a responsabilidade da pesquisadora Dalvina Benicio do Nascimento $O$ projeto é uma pesquisa de Mestrado na área de Bioética na Universidade de Brasília, sob orientação do Prof. Dr. Natan Monsores de Sá, do departamento de Saúde Coletiva e e da Cátedra Unesco de Bioética da UnB.

O objetivo é conhecer a percepção ética dos estudantes da área de saúde sobre a divulgação da imagens/vídeos e informações sobre pacientes em mídias sociais, como facebook e instaram. O(a) senhor(a) receberá todos os esclarecimentos necessários antes e no decorrer da pesquisa e the asseguramos que seu nome não aparecerá em nenhum momento, sendo mantido o mais rigoroso sigilo pela omissão total de quaisquer informações que permitam identificá-lo(a).

Será feita uma pesquisa de natureza descritiva e exploratória com abordagem mista. Será aplicado questionário estruturado com uma questão fechada e 18 questões abertas a serem escritas. Estes procedimentos levarão cerca de 20 minutos.

Os riscos decorrentes de sua participação são possíveis desconfortos pelo ato de ler e escrever, ou tristeza por alguma lembrança, pois a pesquisa não envolve nenhum procedimento invasivo, nem experimentos. Caso sinta algum desconforto ou se sinta muito triste deverá parar de responder as perguntas e comunicar seu estado ao pesquisador que providenciará atendimento de saúde levando-o (a) e acompanhando - o (a) até o profissional que poderá lhe ajudar, preferencialmente em serviço da rede pública mais próxima. Se o (a) senhor (a) aceitar participar, 
poderá contribuir para aumentar a discussão bioética da questão do uso de imagem/vídeos, por estudantes da área de saúde, com as autoridades responsáveis pelos currículos de ensino nas universidades e possibilitar que ocorram melhorias no trato com os pacientes nessa era de grande uso da internet e redes sociais eletrônicas.

$\mathrm{O}$ (a) Senhor(a) pode se recusar a responder a qualquer questão que the traga constrangimento, podendo desistir de participar da pesquisa em qualquer momento, sem nenhum prejuízo para o(a) Senhor(a). Sua participação é voluntária, isto é, não há pagamento por sua colaboração.

$\mathrm{O}$ (a) Senhor(a) não terá nenhum tipo de despesa para participar desta pesquisa.

Caso haja algum dano direto ou indireto decorrente de sua participação na pesquisa, você poderá ser indenizado, obedecendo-se as disposições legais vigentes no Brasil.

Os resultados da pesquisa serão divulgados na Universidade de Brasília, podendo ser publicados posteriormente. Os dados e materiais utilizados na pesquisa ficarão sob a guarda do pesquisador por um período de no mínimo cinco anos, após isso serão destruídos ou mantidos na instituição.

Este projeto foi Aprovado pelo Comitê de Ética em Pesquisa da Faculdade de Ciências da Saúde (CEP/FS) da Universidade de Brasília. O CEP é composto por profissionais de diferentes áreas cuja função é defender os interesses dos participantes da pesquisa em sua integridade e dignidade e contribuir no desenvolvimento da pesquisa dentro de padrões éticos. As dúvidas com relação à assinatura do TCLE ou os direitos do participante da pesquisa podem ser obtidos através do telefone: (61) 3107-1947 ou do e-mail cepfs@unb.br ou cepfsunb@gmail.com, horário de atendimento de 10:00hs às 12:00hs e de 13:30hs às 15:30hs, de segunda a sexta-feira. Se o(a) Senhor(a) tiver qualquer dúvida em relação à pesquisa, por favor contate o pesquisadora Dalvina Benicio Do Nascimento, e-mail: dalvinabn@gmail.com, no telefone 61-99770418 podendo ligar a cobrar, no horário das 8:00 horas às 19:00 de segunda a segunda ou com o Prof. Natan Monsores de Sá, e-mail: natan.monsores@gmail.com, no telefone 31071825, no Campus Darcy Ribeiro - UnB, FS, sala no 119. CEP:70910-900, observatório de doenças raras UnB, de 14h as 17h, Quartas feiras. 
Este documento foi elaborado em duas vias, uma ficará com o pesquisador responsável e a outra com o Senhor(a).

Nome / assinatura

Pesquisador Responsável

Dalvina Benicio do Nascimento

Brasília, de de 
ANEXO - B Informação do corpo do e-mail convidando e esclarecendo os participantes da pesquisa.

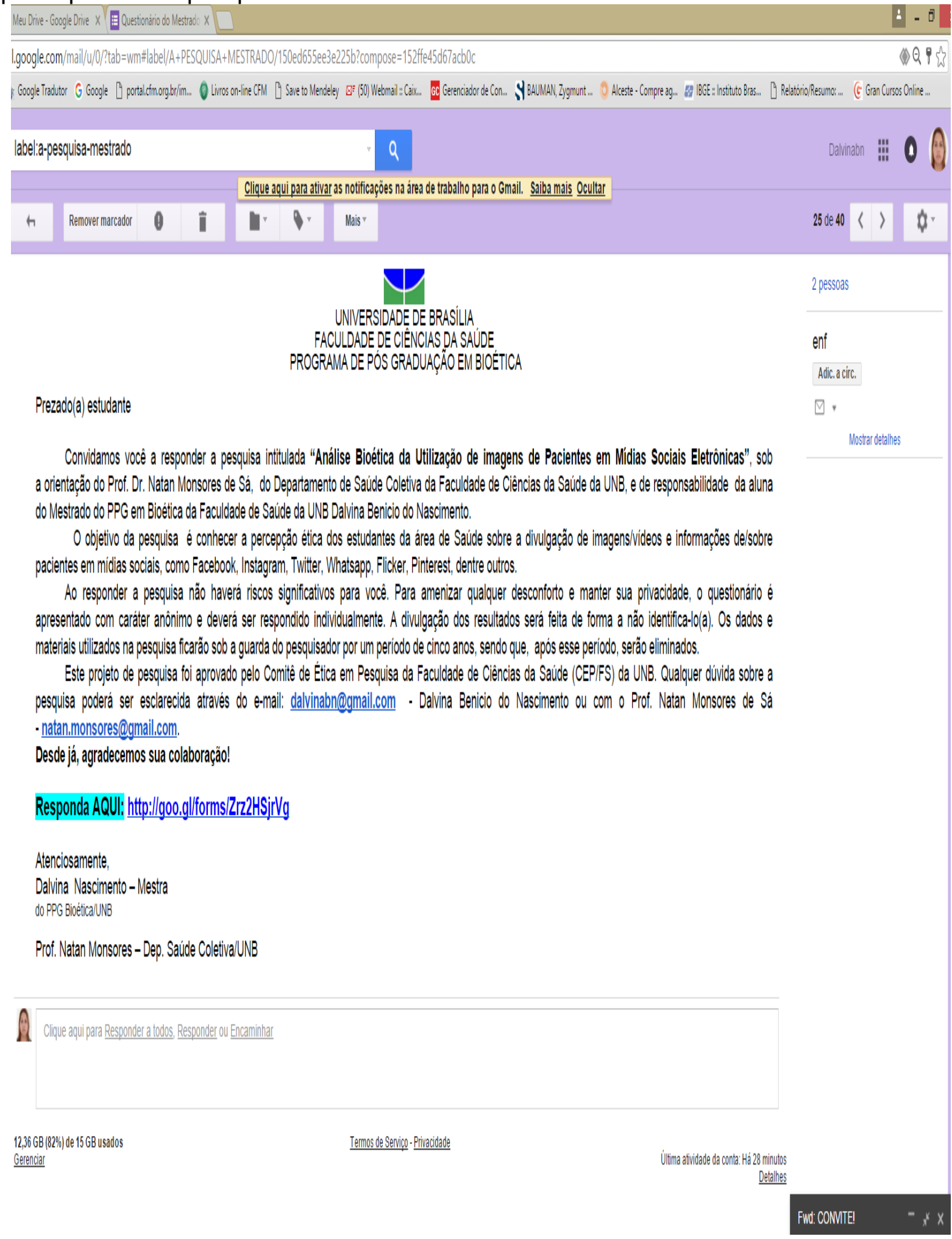


ANEXO - C Questionário criado e aplicado com aplicativo Formulário Google Docs. Questionário de Pesquisa em Bioética

*Obrigatório

\author{
UNIVERSIDADE DE BRASÍLIA \\ FACULDADE DE CIÊNCIAS DA SAÚDE \\ PROGRAMA DE PÓS GRADUAÇÃO EM BIOÉTICA \\ Cátedra UNESCO de Bioética
}

Projeto de pesquisa: ANÁLISE BIOÉTICA DA UTILIZAÇÃo DE IMAGENS DE PACIENTES EM MÍDIAS SOCIAIS ELETRÔNICAS

Pesquisa aprovada no Comitê de Ética da Faculdade de Ciências da Saúde da UnB -

http://fs.unb.br/cep/. Desenvolvida por Dalvina B. Nascimento, Telefone: 61 99770418, e-mail: dalvinabn@gmail.com, e pelo professor Dr. Natan Monsores de Sá, e-mail: monsores@unb.br

Ao responder este questionário você autoriza a utilização das respostas no projeto de pesquisa e nas publicações dele decorrentes? *

Caso sua resposta seja NÃ̃O, não há necessidade de responder o questionário. Agradecemos sua colaboração!

Sim

Não

Gênero *

$\square$ Masculino

$\square$ Feminino

$\square$ Outro:

Quanto a Cor ou Raça,Você se considera *

$\square$ Branca

$\square$ Preta

$\square$ parda

$\square$ Amarela

$\square$ Indígena

$\square$ Sem declaração

Estado civil *

Solteira(o)

Casada(o)

Separada(o) ou Divorciada(o)

Outro:

Local de residência *

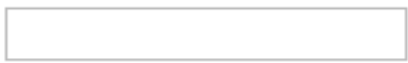

Local de nascimento *

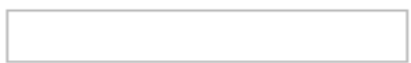


Tem fillhos(as)? *

O Sim

Não

\section{Renda Familiar: *}

Até 01 salário mínimo

01 a 03 salários mínimos

04 a 10 salários mínimos

- 10 a 20 salários mínimos

acima de 20 salários mínimos

Em que instituição estudou o ensino fundamental e médio? *
Pública
Particular
O Outro:

Você é estudante da Universidade de Brasília? *
O Sim
ก Não

Qual é seu curso de graduação? *
O Medicina
Enfermagem
Odontologia
Outro:

Qual semestre está cursando? *

Você já teve contato com paciente(s) durante o curso? *
Sim

Não

Quem você acha que é o protagonista na relação paciente e profissional de saúde? *

O paciente:

O profissional de saúde;

Você já tirou foto ou fez algum filme de paciente? *
O Sim

Não

Se sim, comente onde, quando e por quê?

Você conhece alguém que já tirou foto/filme de paciente? *
Sim
Não 
Ao tirar fotos ou fazer fïlmes de pacientes, você pediu autorização do paciente? *

Sim

$\bigcirc$ Não

Não se aplica

Outro:

Se sim, a autorização foi: *

Verbal

Escrita

Outro:

Havia algum supervisor no momento em que a imagem do paciente foi obtida? *

Sim

Não

Não se aplica

O supervisor presente no momento da obtenção da imagem era: *

Professor

Preceptor

Servidor do hospital

Não se aplica

Outro:

Qual foi a finalidade das fotos ou filmes? *

Estudar o caso

Registro do caso

Divulgar o caso

Não se aplica

Outro:

Q que você fez com as fotos ou filmes após o uso? *

Apagou

O Manteve

Divulgou em redes sociais

Não se aplica

Outro:

Se você divulgou em redes sociais, indique qual foi: *

Facebook

Twitter

Whatsapp

Flicker

Pinterest

Instagram

Não se aplica

Outro:

A foto ou filme foi enviada para algum grupo (aberto ou fechado) na rede social? *

Sim

Não

Se foi enviado para algum grupo, você poderia explicar os motivos? 
Se foi enviado para algum grupo, você poderia explicar os motivos?

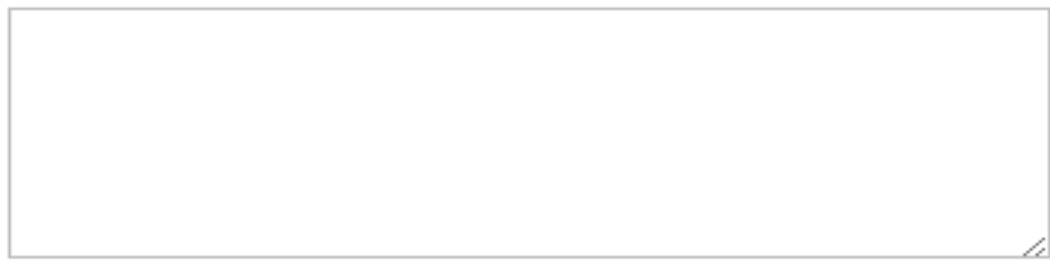

A divulgação da foto/filme teve alguma repercussão, positiva ou negativa?

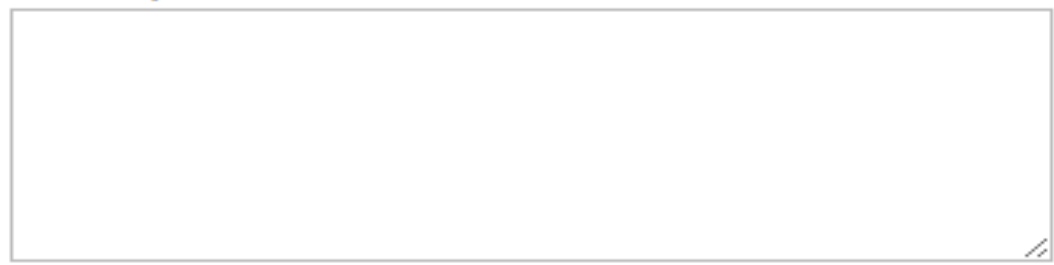

Você autorizaria o compartilhamento de uma foto ou filme, se você fosse o paciente? *

O Sim

Nã。

Outro:

Explique os motivos pelos quais você autorizaria ou não a divulgação de fotos/fílmes seus enquanto paciente. *

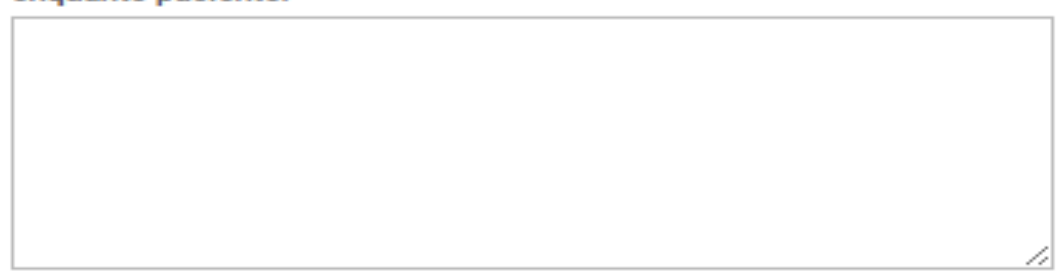

Você acha que existe alguma diferença em tirar e postar uma foto/filme de uma pessoa/paciente e uma paisagem ou natureza morta? *

Sim

Não

Outro:

Você acha que enviar fotos/filmes de pacientes para redes sociais viola algum princípio ético? *

- Sim

Não

Outro:

Se sua resposta foi sim, qual seria(m) o(s) princípio(s) ético(s) violados pela divulgação?

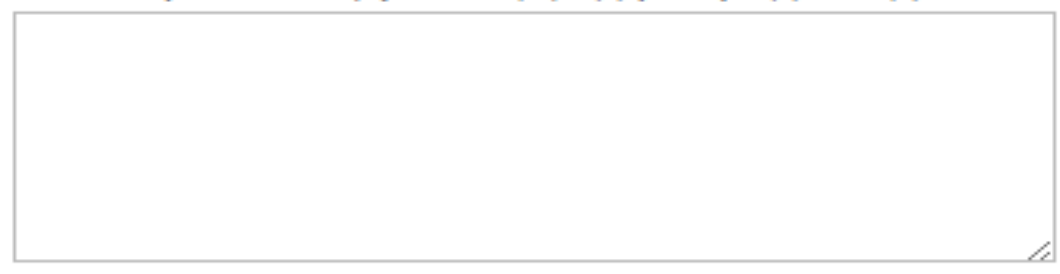

Você conseguiria definir o conceito de autonomia do paciente? Como? *

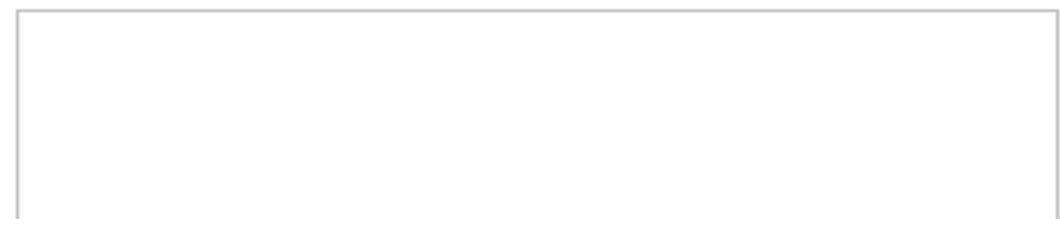


Você conseguiria definir o conceito de privacidade do paciente? Como? *

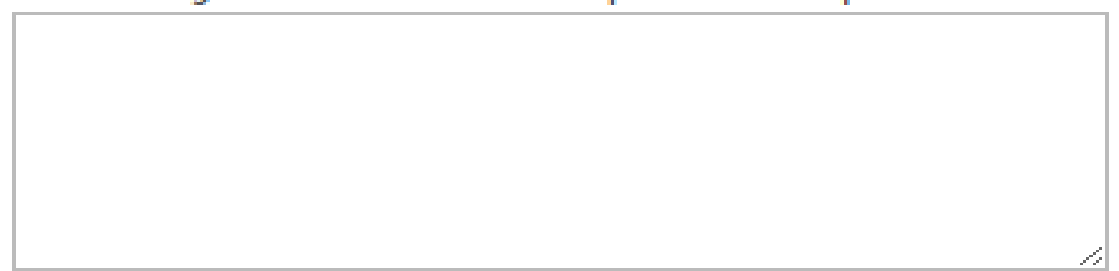

Você conseguiria definir o conceito de confidencialidade? Como? *

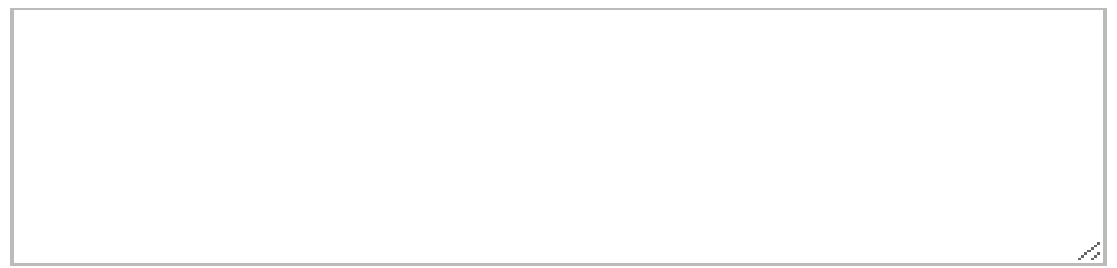

Você conseguiria definir o conceito de sigilo na relação profissional de saúde-paciente? Como? *

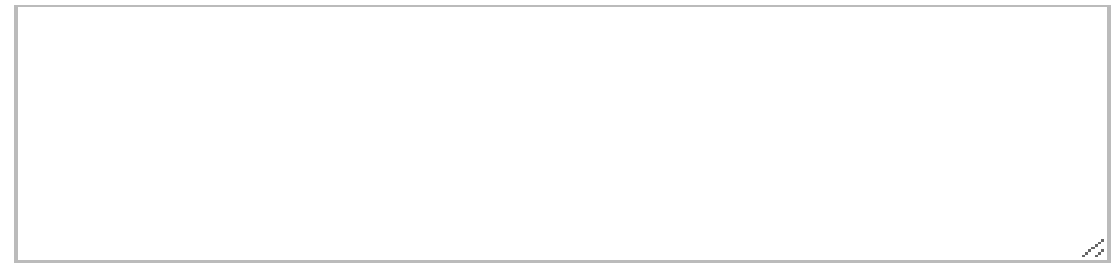

Você conhece alguma norma ou lei que oriente acerca da divulgação de imagens de pessoas? Quais? *

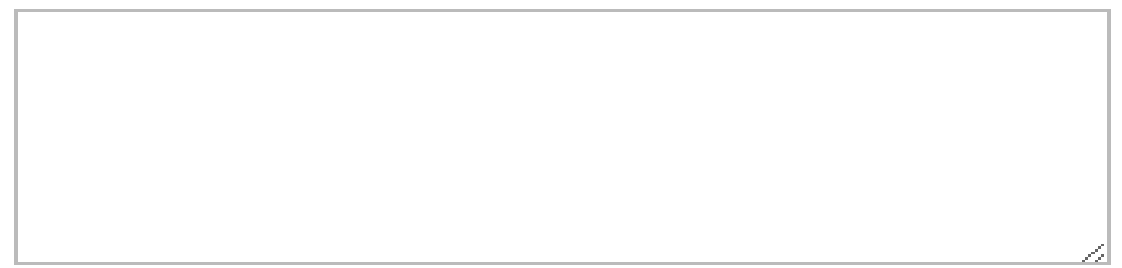

Você quer fazer algum comentário sobre o tema da pesquisa?

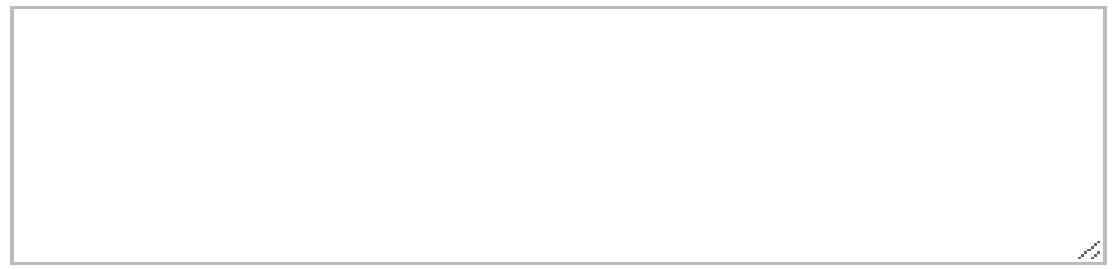

Você deseja deixar seu contato (e-mail, telefone, etc.)?

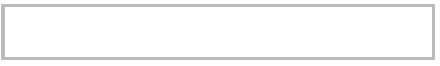

Obrigada por sua colaboração!

$\mathrm{dd} / \mathrm{mm} / \mathrm{aaaa}$ 
APÊNDICE - A Parecer de aprovação da pesquisa no Comitê de Ética da FS/UnB Universidade de Brasília Faculdade de Ciências da Saúde Comitê de Ética em Pesquisa - CEP/FS

\section{PROCESSO DE ANÁLISE DE PROJETO DE PESQUISA}

Título do Projeto: "ANÁLISE BIOÉTICA DA UTILIZAÇÃO DE IMAGENS DE PACIENTES EM MÍDIAS SOCIAIS ELETRÔNICAS"

Pesquisadora Responsável: DALVINA BENICIO DO NASCIMENTO

Data de Entrada: 16/07/2015

CAAE: 46362015.9 .0000 .0030$.

Com base na Resolução 466/12, do CNS/MS, que regulamenta a ética em pesquisa com seres humanos, o Comitê de Ética em Pesquisa com Seres Humanos da Faculdade de Ciências da Saúde da Universidade de Brasília, após análise dos aspectos éticos e do contexto técnico-científico, resolveu APROVAR o projeto intitulado "ANÁLISE BIOÉTICA DA UTILIZAÇÃO DE IMAGENS DE PACIENTES EM MÍdTAS SOCIAIS ELETRÔNICAS". Parecer no 1.184.221, em 13 de agosto de 2015.

Notifica-se o(a) pesquisador(a) responsável da obrigatoriedade da apresentação de um relatório semestral e relatório final sobre o desenvolvimento do projeto, no prazo de 1 (um) ano a contar da data de aprovação.

Brasília, 26 de agosto de 2015.

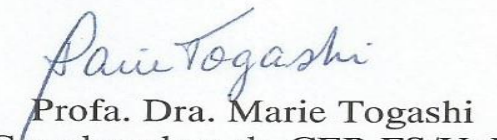

Cbordenadora do CEP-FS/UnB

Comitê de Ética em Pesquisa com Seres Humanos - Faculdade de Ciências da Saúde

Universidade de Brasília - Campus Universitário Darcy Ribeiro - CEP: 70.910-900

Telefone: (61)-3107-1947 Email: cepfs@unb.br 